\title{
Land Mollusk Surveys on USFS Northern Region Lands
}

\author{
Prepared for: \\ USDA Forest Service, Northern Region \\ P.O. Box 7669 \\ Missoula, MT 59807
}

By:

Paul Hendricks, Bryce A. Maxell and Susan Lenard

Montana Natural Heritage Program

Natural Resource Information System

Montana State Library

May 2006

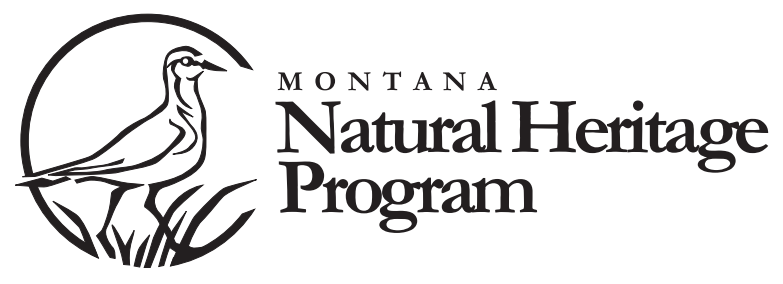





\title{
Land Mollusk Surveys on USFS Northern Region Lands
}

\author{
Prepared for: \\ USDA Forest Service, Northern Region \\ P.O. Box 7669 \\ Missoula, MT 59807
}

Agreement Number:

\#05-CS-110115600-033

By:

Paul Hendricks, Bryce A. Maxell and Susan Lenard
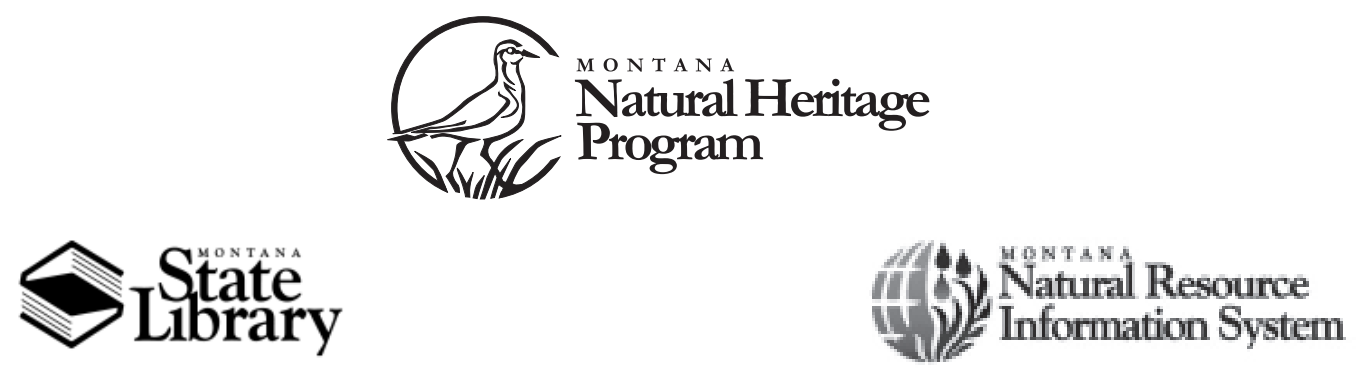

(c) 2006 Montana Natural Heritage Program

P.O. Box $201800 \bullet 1515$ East Sixth Avenue • Helena, MT 59620-1800 • 406-444-5354 
This document should be cited as follows:

Hendricks, P., B. A. Maxell and S. Lenard. 2006. Land Mollusk Surveys on USFS Northern Region Lands. A report to the USDA Forest Service, Northern Region. Montana Natural Heritage Program, Helena, Montana. 11 pp. plus appendices. 


\section{Executive Summary}

Using prior published reports and the NatureServe web site as starting points, we compiled a list of 29 snail taxa within the U.S. Forest Service Northern Region (Region 1) area ranked in 2005 as G1-G3 or T1-T3, thereby meeting USFS Species of Concern (SOC) criteria, and two additional G5 snail taxa ranked S1-S2, thereby meeting USFS Species of Interest (SOI) criteria. We also compiled a list of eight slug taxa ranked in 2005 as G1-G3, and three additional slug taxa ranked G4-G5 but S1-S2, again meeting the respective USFS criteria for SOC or SOI.

We conducted a total of 108 site surveys in 2005 targeting areas lacking previous information on terrestrial mollusks. These were distributed on the Montana Forests as follows: BeaverheadDeerlodge (13), Bitterroot (0), Custer (8), Flathead (9), Gallatin (17), Helena (13), Kootenai (5), Lewis \& Clark (19), Lolo (1). We distributed surveys on the Idaho Forests as follows: Clearwater (11), Idaho Panhandle (4), Nez Perce (8).

We documented 83 new locations for ten SOC taxa and three SOI taxa during our 2005 surveys: Selway Forestsnail Allogona lombardii (3 sites), Nimapuna Tigersnail Anguispira nimapuna (4 sites), Striate Disc Discus shimeki (1 site), Berry's Mountainsnail Oreohelix strigosa berryi (6 sites), Robust Lancetooth Haplotrema vancouverense (4 sites), Humped Coin Polygyrella polygyrella (6 sites), Fir Pinwheel Radiodiscus abietum (16 sites), Pale Jumping-slug Hemphillia camelus (9 sites), Pygmy Slug Kootenaia burkei (6 sites), Reticulate Taildropper Prophysaon andersoni (1 site), Smoky Taildropper Prophysaon humile (16 sites), Lyre Mantleslug Udosarx lyrata (2 sites), and Sheathed Slug Zacoleus idahoensis (9 sites). Most locations are from west of the Continental Divide in mesic forest habitats (e.g., western redcedar, western hemlock, mesic Douglas-fir, grand fir).

Two SOC and one SOI slug species, all discovered on the Kootenai National Forest, are new to the known mollusk fauna of Montana: Pale Jumpingslug, Pygmy Slug, and Reticulate Taildropper. The 2005 survey added seven new Montana locations and nine new Idaho locations for a third SOC slug species, Smoky Taildropper, which was documented in Montana only once prior to 2004. As a result of the 2005 surveys, Global Ranks shifted downward for five species (Humped Coin, Fir Pinwheel, Pale Jumping-slug, Pygmy Slug, and Smoky Taildropper). We also collected distribution data on 21 additional non-SOC species as we encountered them during our surveys.

At least some SOI G4-G5 taxa found during our 2005 surveys may prove to be distinct from related coastal populations, as their disjunct distributions are similar to some vertebrate amphibian taxa (e.g., Dicamptodon, Ascaphus, Plethodon) now split into coastal and Rocky Mountain sister species. Therefore, we think it desirable to conduct genetic analyses of several mollusk SOC and SOI taxa to determine it they represent forms that merit full species status. Additional inventory is also desirable to fill remaining distribution gaps, describe habitat associations thoroughly enough to develop predictive distribution models, and lay the foundation for developing a long-term monitoring scheme and standardized survey methodology. 


\section{ACKNOWLEDGEMENTS}

Fred Samson (USFS) recognized the need to address invertebrates in the Forest planning process, appreciating the extremely limited information available for management decisionmaking, and promoted the project through the USFS Regional Inventory and Monitoring (RIM) program. Henning Stabins (Plum Creek Timber Company) and the Amphibian Inventory Project provided us with additional records of SOC mollusk species that helped fill significant gaps in distributions. Bill Bosworth, zoologist with the Idaho Conservation Data Center, provided the Montana Natural Heritage Program (MTNHP) with location data on SOC species tracked in the Idaho portions of the Northern Region; the Idaho records were especially critical for the production of new distribution maps, and fleshing out distributions of rare land mollusk species that occur on both sides of the Idaho-Montana border. Bill Leonard (Olympia, WA) and Tim Pearce (Carnegie Museum of Natural History) verified our tentative SOC and SOI slug identifications. Matthew Gates assisted with field surveys. Coburn Currier (MTNHP) assisted on some surveys and formatted and printed this report. We thank them all. 


\section{TABLe OF Contents}

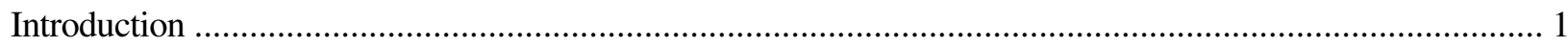

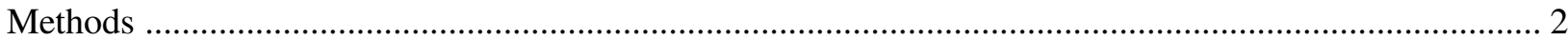

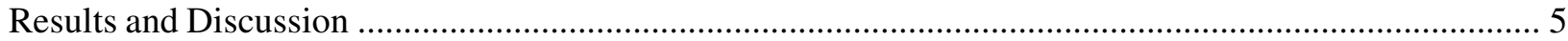

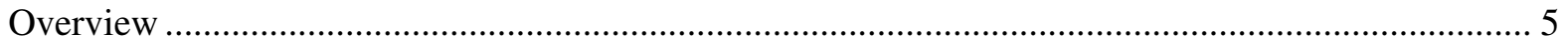

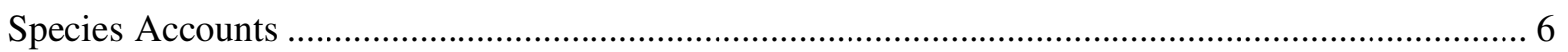

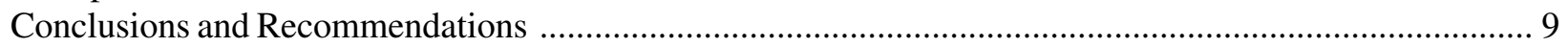

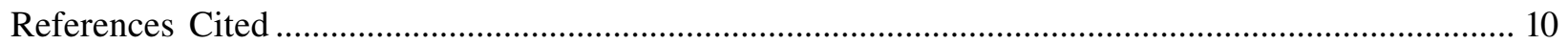

Appendix A. Global/State Rank Definitions

Appendix B. USFS Region 1 Survey Sites for Land Mollusks in 2005

Appendix C. Standaridized Data Sheets

Appendix D. Example Species Photograpshs

Appendix E. Distribution Maps for SOC/SOI Land Mollusks on USFS Region 1 Lands

Appendix F. Distribution Maps for Non-SOC Land Mollusks on USFS Region 1 Lands

Appendix G. Distribution Maps for Exotic Land Mollusks on USFS Region 1 Lands

\section{LIST OF TABLES}

Table 1. Species of Concern land mollusks: distribution by Forest in Region 1 ..................................... 2

Table 2. Species of Concern land mollusks: habitat associations .......................................................... 3

Table 3. Number of survey sites where Species of Concern land mollusks were detected on Northern Region Forests during 2005 survey ...................................................................................... 5 



\section{INTRODUCTION}

Within and adjacent to the landscape bounded by the Northern Region are a large number of land mollusk species that are endemic to the Northern Rocky Mountains, and several additional species are restricted to the Pacific Northwest, with disjunct populations in northern Idaho and northwestern Montana (Frest and Johannes 1995, 1997, 2001; Hendricks 2003). Parts of the survey area, especially portions of the Lower Salmon River drainage, were recognized relatively early as centers of mollusk endemism, and drew attention of several early collectors (Frest and Johannes 1997). Nevertheless, many areas in Idaho as well as Montana were never visited or remain poorly inventoried, as demonstrated by the recent discovery of a new slug genus in northern Idaho (Leonard et al. 2003). Limited survey of the region is partly a result of timing. When much pioneering collecting of the terrestrial mollusk fauna was undertaken, roughly 1860-1950, many portions of the survey area were difficult to reach without significant commitment of time and resources. During the mid and late $20^{\text {th }}$ century, when road access across the study area increased dramatically, far fewer malacologists were resident or active in the region. Only recently has there been recognition by biologists that many mollusk species in the region are threatened with a variety of potentially detrimental land use activities, prompting renewed inventories.

The FS is required under the National Forest Management Act (1976) and Code of Federal Regulations (CFR 1985) to maintain a diversity of plant and animal species. Inventory is a first step in the evaluation of landscapes and their likelihood of supporting populations of animal species of conservation concern. Pursuant with this legislation and associated regulations, the Northern Region initiated surveys in 2005 for a suite of land mollusks listed as Species of Concern in Montana and Idaho. Objectives of the 2005 inventory included filling species distribution gaps, testing survey methodology, and collecting geospatial and habitat data for the development of predictive habitat models that can aid future survey efforts. 


\section{MeTHODS}

Prior to conducting field surveys, we searched the published and gray literature to compile a list of high-priority "target" species (globally and state rare species in Montana, and globally rare species in Idaho). Primary sources we used for this compilation included Pilsbry $(1939,1948)$, Frest and Johannes (1995, 1997, 2001), and Hendricks (2003). This resulted in a list of 42 species and subspecies (31 snails, 11 slugs) we considered to be of conservation concern (Table 1); only eight of these taxa are ranked less than G3 (see Appendix A for ranks definitions). We then generated a list of general habitat associations for the high-priority species (Table 2), to help us prioritize habitats for survey. Limited information for mollusks east of the Continental Divide in Montana made this process more problematic for the high-priority species that occur or might occur in that region.

Table 1. Species of Concern land mollusks: distribution by Forest in Region 1. G Ranks of species in bold changed as a result of our 2005 surveys (see text for previous ranks).

\begin{tabular}{|c|c|c|c|c|c|c|c|c|c|c|c|c|c|}
\hline \multirow[b]{2}{*}{ SPECIES } & \multirow[b]{2}{*}{ G RANK } & \multicolumn{9}{|c|}{ Montana $^{\mathrm{a}}$} & \multicolumn{3}{|c|}{ Idaho $^{\mathrm{b}}$} \\
\hline & & B-D & BI & $\mathbf{C U}$ & $\mathbf{F L}$ & GA & HE & KO & L-C & LO & CL & I-P & N-P \\
\hline \multicolumn{14}{|l|}{ Snails } \\
\hline Allogona lombardii (ID) & G1 & & & & & & & & & & & & $\mathrm{x}$ \\
\hline Allogona ptychophora solida (ID)? & G5T2T3 & & & & & & & & & & & & $?$ \\
\hline Anguispira nimapuna (ID) & G1 & & & & & & & & & & $\mathrm{x}$ & & $\mathrm{x}$ \\
\hline Cryptomastix harfordiana (ID)? & G3G4 & & & & & & & & & & & & $?$ \\
\hline Cryptomastix magnidentata(ID)? & G1 & & & & & & & & & & & & $?$ \\
\hline Cryptomastix mullani blandi (ID)? & G4T1 & & & & & & & & & & & $?$ & \\
\hline Cryptomastix mullani clappi (ID) & G4T1 & & & & & & & & & & & & $\mathrm{x}$ \\
\hline Cryptomastix sanburni (ID)? & G1 & & & & & & & & & & & $?$ & \\
\hline Discus brunsoni (MT)? & G1 & & & & $?$ & & & & & & & & \\
\hline Discus marmorensis (ID) & G1G3 & & & & & & & & & & & & $\mathrm{x}$ \\
\hline Discus shimekii (MT, ID?) & G5 & & & & & $\mathrm{x}$ & & $\mathrm{X}$ & & & & $?$ & \\
\hline Haplotrema vancouverense* $(\mathrm{MT}, \mathrm{ID})$ & G5 & & & & & & & $\mathrm{x}$ & & & $\mathrm{x}$ & $\mathrm{x}$ & \\
\hline Helicodiscus salmonaceus (ID) & G1G2 & & & & & & & & & & & & $\mathrm{x}$ \\
\hline Oreohelix alpina $(\mathrm{MT})$ & G1 & & & & $\mathrm{x}$ & & & & & & & & \\
\hline Oreohelix amariradix (MT) & G1G2 & & & & & & & & & $\mathrm{x}$ & & & \\
\hline Oreohelix carinifera $(\mathrm{MT})$ & G1 & & & & & & & & & $\mathrm{x}$ & & & \\
\hline Oreohelix elrodi (MT) & G1 & & & & $\mathrm{x}$ & & & & & & & & \\
\hline Oreohelix hammeri (ID) & G1 & & & & & & & & & & & & $\mathrm{x}$ \\
\hline Oreohelix idahoensis baileyi (ID) & G1G2T1 & & & & & & & & & & & & $\mathrm{x}$ \\
\hline Oreohelix idahoensis idahoensis (ID)? & G1G2T1T2 & & & & & & & & & & & & $?$ \\
\hline Oreohelix intersum (ID)? & G1 & & & & & & & & & & & & $?$ \\
\hline Oreohelix jugalis (ID)? & G1 & & & & & & & & & & & & $?$ \\
\hline Oreohelix strigosa berryi (MT) & G5T2 & & & $\mathrm{x}$ & & $\mathrm{x}$ & $\mathrm{x}$ & & $\mathrm{x}$ & & & & \\
\hline Oreohelix strigosa goniogyra (ID) & G5T1Q & & & & & & & & & & & & $\mathrm{x}$ \\
\hline Oreohelix vortex (ID)? & G1G3 & & & & & & & & & & & & $?$ \\
\hline Oreohelix waltoni $(\mathrm{ID}) ?$ & G1G3 & & & & & & & & & & & & $?$ \\
\hline Oreohelix yavapai mariae (MT) & G4T1 & & & & & $\mathrm{x}$ & & & & & & & \\
\hline Planogyra clappi (ID) & G3G4 & & & & & & & & & & & & $\mathrm{x}$ \\
\hline Polygyrella polygyrella (MT, ID) & G3 & & & & & & & & & $\mathrm{x}$ & $\mathrm{x}$ & & $\mathrm{x}$ \\
\hline Pristiloma idahoense (ID) & G2G3 & & & & & & & & & & & & $\mathrm{x}$ \\
\hline Radiodiscus abietum (MT, ID) & G4 & & $\mathrm{x}$ & & $\mathrm{x}$ & & & $\mathrm{x}$ & & $\mathrm{x}$ & $\mathrm{x}$ & $\mathrm{x}$ & $\mathrm{x}$ \\
\hline \multicolumn{14}{|l|}{ Slugs } \\
\hline Hemphillia camelus* (MT, ID) & G4 & & & & & & & $\mathrm{x}$ & & $\mathrm{x}$ & $\mathrm{x}$ & $\mathrm{x}$ & $\mathrm{x}$ \\
\hline Hemphillia danielsi (MT) & G2G3 & & $\mathrm{x}$ & & & & & & & $?$ & & & \\
\hline Kootenaia burkei* (MT, ID) & G2 & & & & & & & $\mathrm{x}$ & & & & $\mathrm{x}$ & \\
\hline Magnipelta mycophaga (MT, ID) & G3 & & $\mathrm{x}$ & & $\mathrm{x}$ & & & $\mathrm{x}$ & & $\mathrm{x}$ & $\mathrm{x}$ & $\mathrm{x}$ & \\
\hline Prophysaon andersoni $*(\mathrm{MT}, \mathrm{ID})$ & G5 & & & & & & & $\mathrm{x}$ & & & & $?$ & \\
\hline Prophysaon coeruleum (ID) & G4 & & & & & & & & & & & $\mathrm{x}$ & \\
\hline Prophysaon dubium (ID) & G4 & & & & & & & & & & & $\mathrm{x}$ & \\
\hline Prophysaon humile* (MT, ID) & G3 & & & & $\mathrm{x}$ & & & $\mathrm{X}$ & & $\mathrm{x}$ & $\mathrm{x}$ & $\mathrm{x}$ & $\mathrm{x}$ \\
\hline Udosarx lyrata lyrata (MT, ID) & G2T2 & & $\mathrm{x}$ & & & & & & & $?$ & $\mathrm{x}$ & & \\
\hline Udosarx lyrata russelli (MT)? & G2T1 & & & & & & & & & $?$ & & & \\
\hline Zacoleus idahoensis (MT, ID) & G3G4 & $\mathrm{x}$ & & & & & & $\mathrm{x}$ & & $\mathrm{x}$ & $\mathrm{x}$ & $\mathrm{x}$ & $\mathrm{x}$ \\
\hline
\end{tabular}

a Montana Forests codes: Beaverhead-Deerlodge (B-D), Bitterroot (BI), Custer (CU), Flathead (FL), Gallatin (GA), Helena (HE), Kootenai (KO), Lewis \& Clark (L-C), Lolo (LO).

${ }^{b}$ Idaho Forest codes: Clearwater (CL), Idaho Panhandle (I-P), Nez Perce (N-P).

* new species for Montana SoC list

? taxon apparently not yet recorded on USFS Region 1 lands, but in area and should be looked for 
Table 2. Species of Concern land mollusks: habitat associations. G Ranks of species in bold changed as a result of our 2005 surveys (see text for previous ranks).

\begin{tabular}{|c|c|c|c|c|c|c|c|c|c|}
\hline \multirow[b]{2}{*}{ Species } & \multirow[b]{2}{*}{ G Ranks } & \multicolumn{3}{|c|}{$\begin{array}{c}\text { Moist Mixed-conifer Forest } \\
\text { Riparian }\end{array}$} & \multirow[t]{2}{*}{ Aspen } & \multicolumn{3}{|c|}{ Dry Mixed-conifer Forest } & \multirow[t]{2}{*}{$\begin{array}{c}\begin{array}{c}\text { Limestone } \\
\text { Talus* }\end{array} \\
\end{array}$} \\
\hline & & $\begin{array}{c}\text { Cedar- } \\
\text { hemlock, } \\
\text { grand fir, } \\
\text { Doug-fir }\end{array}$ & $\begin{array}{l}\text { Spruce- } \\
\text { fir }\end{array}$ & $\begin{array}{l}\text { Talus- } \\
\text { rocky } \\
\text { ground }\end{array}$ & & $\begin{array}{l}\text { Ponderosa } \\
\text { pine, } \\
\text { Doug-fir }\end{array}$ & $\begin{array}{l}\text { Juniper- } \\
\text { sage }\end{array}$ & $\begin{array}{l}\text { Talus- } \\
\text { rocky } \\
\text { ground }\end{array}$ & \\
\hline \multicolumn{10}{|l|}{ SNAILS } \\
\hline Allogona lombardii (ID) & G1 & $\mathrm{x}$ & & & & & & & \\
\hline Allogona ptychophora solida (ID)? & G5T2T3 & & & & & & $\mathrm{x}$ & $\mathrm{x}$ & \\
\hline Anguispira nimapuna (ID) & G1 & $\mathrm{x}$ & & $\mathrm{x}$ & & $\mathrm{x}$ & & $\mathrm{x}$ & \\
\hline Cryptomastix harfordiana (ID)? & G3G4 & & & & & & & $\mathrm{x}$ & $\mathrm{x}$ \\
\hline Cryptomastix magnidentata (ID)? & G1 & & & $\mathrm{x}$ & & & & $\mathrm{x}$ & $\mathrm{x}$ \\
\hline Cryptomastix mullani blandi (ID)? & G4T1 & & & $\mathrm{x}$ & & & & & \\
\hline Cryptomastix mullani clappi (ID) & G4T1 & & & & & & & $\mathrm{x}$ & \\
\hline Cryptomastix sanburni (ID)? & G1 & & & $\mathrm{x}$ & & & & & \\
\hline Discus brunsoni (MT)? & G1 & & & $\mathrm{x}$ & & & & & \\
\hline Discus marmorensis (ID) & G1G3 & $\mathrm{x}$ & & $\mathrm{x}$ & & $\mathrm{x}$ & & & $\mathrm{x}$ \\
\hline Discus shimekii (MT, ID?) & G5 & & & & $\mathrm{x}$ & $\mathrm{x}$ & & & \\
\hline Haplotrema vancouverense (MT,ID)\# & G5 & $\mathrm{x}$ & & & & & & & \\
\hline Helicodiscus salmonaceus (ID) & G1G2 & & & $\mathrm{x}$ & & & & $\mathrm{x}$ & \\
\hline Oreohelix alpina $(\mathrm{MT})$ & G1 & & & $\mathrm{x}$ & & & & & $\mathrm{x}$ \\
\hline Oreohelix amariradix (MT) & G1G2 & & & & & $\mathrm{x}$ & & $\mathrm{x}$ & \\
\hline Oreohelix carinifera $(\mathrm{MT})$ & G1 & & & & & $\mathrm{x}$ & $\mathrm{x}$ & $\mathrm{x}$ & $\mathrm{x}$ \\
\hline Oreohelix elrodi $(\mathrm{MT})$ & G1 & & & $\mathrm{x}$ & & & & & \\
\hline Oreohelix hammeri (ID) & G1 & & & & & & & $\mathrm{x}$ & $\mathrm{x}$ \\
\hline Oreohelix idahoensis baileyi (ID) & G1G2T1 & & & & & & & $\mathrm{x}$ & $\mathrm{x}$ \\
\hline O. i. idahoensis (ID)? & G1G2T1T2 & & & & & & $\mathrm{x}$ & $\mathrm{x}$ & $\mathrm{x}$ \\
\hline Oreohelix intersum (ID)? & G1 & & & & & & & $\mathrm{x}$ & \\
\hline Oreohelix jugalis (ID)? & G1G2 & & & & & & & $\mathrm{x}$ & \\
\hline Oreohelix strigosa berryi (MT) & G5T2 & & & & & $\mathrm{X}$ & & $\mathrm{x}$ & $\mathrm{x}$ \\
\hline O.s. goniogyra (ID) & G5T1Q & & & & & $\mathrm{x}$ & & $\mathrm{x}$ & \\
\hline Oreohelix vortex (ID)? & G1G3 & & & & & & & $\mathrm{x}$ & \\
\hline Oreohelix waltoni (ID)? & G1G3 & & & & & & $\mathrm{x}$ & $\mathrm{x}$ & \\
\hline Oreohelix yavapai mariae (MT) & G4T1 & & & & & & & $\mathrm{x}$ & $\mathrm{x}$ \\
\hline Planogyra clappi (ID) & G3G4 & $\mathrm{x}$ & & & & & & & \\
\hline Polygyrella polygyrella (MT, ID) & G3 & $\mathrm{x}$ & $\mathrm{x}$ & $\mathrm{x}$ & & & & $\mathrm{x}$ & \\
\hline Pristiloma idahoense (ID) & G2 & $\mathrm{x}$ & & $\mathrm{x}$ & & & & & \\
\hline Radiodiscus abietum (MT, ID) & G4 & $\mathrm{x}$ & $\mathrm{x}$ & $\mathrm{x}$ & & & & & \\
\hline \multicolumn{10}{|l|}{ SLUGS } \\
\hline Hemphillia camelus (MT, ID) & G4 & $\mathrm{x}$ & $\mathrm{X}$ & & & & & & \\
\hline Hemphillia danielsi (MT) & G2G3 & $\mathrm{x}$ & $\mathrm{x}$ & & & & & & \\
\hline Kootenaia burkei (MT, ID) & G2 & $\mathrm{x}$ & & & & & & & \\
\hline Magnipelta magnipelta (MT, ID) & G3 & $\mathrm{x}$ & $\mathrm{x}$ & $\mathrm{x}$ & & $\mathrm{x}$ & & & \\
\hline Prophysaon andersoni $(\mathrm{MT}, \mathrm{ID}) \#$ & G5 & $\mathrm{x}$ & & & & & & & \\
\hline Prophysaon coeruleum (ID)\# & G4 & $\mathrm{x}$ & & & & & & & \\
\hline Prophysaon dubium (ID)\# & G4 & $\mathrm{x}$ & & $\mathrm{x}$ & & & & & \\
\hline Prophysaon humile (MT, ID) & G3 & $\mathrm{x}$ & $\mathrm{x}$ & $\mathrm{x}$ & & & & & \\
\hline Udosarx lyrata lyrata (MT, ID) & G2T2 & $\mathrm{x}$ & $\mathrm{x}$ & & & & & & \\
\hline U.l. russelli (MT)? & G2T1 & & & $\mathrm{x}$ & & $\mathrm{x}$ & & & \\
\hline Zacoleus idahoensis (MT, ID) & G3G4 & $\mathrm{x}$ & $\mathrm{x}$ & & & & & & \\
\hline
\end{tabular}

\#. These low G-rank taxa may prove to be distinct from coastal populations, as their disjunct distributions are similar to individual vertebrate taxa (e.g. Dicamptodon, Ascaphus, Plethodon) now split into coastal and Rocky Mountain species.

* Limestone talus associates may occur in either dry or moist sites, but are most often limestone or limestone-derived soil obligates

We conducted field surveys for land mollusks during mid-September to early November 2005, when the weather was most suitable (cool and moist) for finding active snails and slugs. We attempted to visit all 12 National Forests in the Northern Region, so survey effort was stratified by Forest (sometimes by mountain range within a forest) and spread thinly across the inventory area (sites surveyed are listed in Appendix B). However, we spent the most time on Forests with the least amount of prior survey effort or distribution information. Forests in Idaho were an exception because we were not aware at the time of our 2005 surveys how much survey history they already had.

We selected sites for surveys based primarily on the presence of perennial water, moist mature conifer forest, aspen, and/or limestone talus or other rock outcrops. At each site, we conducted 
timed surveys while searching under leaf litter, dead wood and bark, rocks imbedded in the ground, or digging into talus. Usually within a survey site we searched several locations with habitat features (such as bryophyte mats, dead wood and imbedded rocks, or talus slopes) considered by experts to be favored by snails and slugs, often concentrating searches in riparian zones.

We recorded a variety of habitat and site information at each survey location on standardized data forms (Appendix C). Survey data have been entered into the Montana Natural Heritage Program Point Observation Database (POD); copies of the Idaho data have been sent to the Idaho Conservation Data Center (CDC) in Boise. We collected voucher specimens of all Species of Concern (SOC) that we discovered, as well as representatives of many other non-SOC taxa; vouchers were preserved in $95 \%$ ethanol in order to permit future genetic analyses. We sent all slug specimens from Idaho and Montana west of the Continental Divide to taxonomic experts, and their identifications have been verified. 


\section{Results AND Discussion}

\section{Overview}

We conducted a total of 108 site surveys in 2005 (Appendix B). These were distributed on the Montana Forests as follows: Beaverhead-

Deerlodge (13), Bitterroot (0), Custer (8), Flathead (9), Gallatin (17), Helena (13), Kootenai (5), Lewis \& Clark (19), Lolo (1). We distributed surveys on the Idaho Forests as follows: Clearwater (11), Idaho Panhandle (4), Nez Perce (8). Some landscapes within the survey area of the Northern Region were bypassed because they fell mostly outside U.S. Forest Service land ownership or they had received prior survey attention in recent years. Therefore, we conducted few surveys in the Lower Salmon River area of Idaho and none in the Bitterroot Mountains, Mission Mountains, and Swan Valley of northwestern Montana, despite these being areas of significant land mollusk endemism and with additional records of rare regional species (Solem 1975; Fairbanks 1984; Frest and Johannes 1995, 1997, 2001; Hendricks 1998, 2003).

We documented 83 new locations for ten SOC taxa and three SOI taxa during our 2005 surveys (Table 3): Selway Forestsnail Allogona lombardii (3 sites), Nimapuna Tigersnail Anguispira nimapuna (4 sites), Striate Disc Discus shimeki (1 site),
Berry's Mountainsnail Oreohelix strigosa berryi (6 sites), Robust Lancetooth Haplotrema vancouverense (4 sites), Humped Coin Polygyrella polygyrella (6 sites), Fir Pinwheel Radiodiscus abietum (16 sites), Pale Jumping-slug Hemphillia camelus (9 sites), Pygmy Slug Kootenaia burkei (6 sites), Reticulate Taildropper Prophysaon andersoni (1 site), Smoky Taildropper Prophysaon humile (16 sites), Lyre Mantleslug Udosarx lyrata (2 sites), and Sheathed Slug Zacoleus idahoensis (9 sites). Most new locations are from west of the Continental Divide in moist forest habitats (e.g., western redcedar, western hemlock, grand fir, mesic Douglas-fir). Two SOC and one SOI slug species, all discovered on the Kootenai National Forest, are new to the known mollusk fauna of Montana: Pale Jumpingslug, Pygmy Slug, and Reticulate Taildropper. The 2005 survey added seven new Montana locations and nine new Idaho locations for a third SOC slug species, Smoky Taildropper, which was documented in Montana only once prior to 2004. We were most surprised by our failure to document any locations of Magnum Mantleslug (Magnipelta mycophaga) during our autumn 2005 survey, although several new western Montana sites were found during other surveys in 2004 and spring 2005 (e.g., Appendix E; Hendricks 2005).

Table 3. Number of survey sites where Species-of-Concern land mollusks were detected on Northern Region Forests during the 2005 survey $(n=108$ sites). G Ranks of species in bold changed as a result of our 2005 surveys (see text for previous ranks). Species common names with an * are newly documented Montana fauna.

\begin{tabular}{|c|c|c|c|c|c|c|c|c|c|c|c|c|c|c|}
\hline & \multirow[b]{2}{*}{ SPECIES } & \multirow[b]{2}{*}{ G RANK } & \multicolumn{9}{|c|}{ Montana $^{\mathrm{a}}$} & \multicolumn{3}{|c|}{ Idaho $^{\mathrm{b}}$} \\
\hline & & & B-D & BI & $\mathbf{C U}$ & FL & GA & HE & KO & L-C & LO & $\mathbf{C L}$ & I-P & N-P \\
\hline \multicolumn{15}{|l|}{ SNAILS } \\
\hline Selway Forestsnail & Allogona lombardii (ID) & G1 & & & & & & & & & & & & 3 \\
\hline Nimapuna Tigersnail & Anguispira nimapuna (ID) & G1 & & & & & & & & & & 1 & & 3 \\
\hline Striate Disc & Discus shimekii (MT, ID?) & G5 & & & & & 1 & & & & & & & \\
\hline Robust Lancetooth & Haplotrema vancouverense (MT, ID) & G5 & & & & & & & & & & 2 & 2 & \\
\hline Berry's Mountainsnail & \begin{tabular}{|l} 
Oreohelix strigosa berryi (MT) \\
\end{tabular} & G5T2 & & & 1 & & & 1 & & 4 & & & & \\
\hline Humped Coin & Polygyrella polygyrella (MT, ID) & G3 & & & & & & & & & & 3 & & 3 \\
\hline Fir Pinwheel & Radiodiscus abietum (MT, ID) & G4 & & & & 1 & & & 4 & & & 6 & 2 & 3 \\
\hline \multicolumn{15}{|l|}{ SLUGS } \\
\hline Pale Jumping-slug* & Hemphillia camelus (MT, ID) & G4 & & & & & & & 1 & & & 2 & 1 & 5 \\
\hline Pygmy Slug* & Kootenaia burkei (MT, ID) & G2 & & & & & & & 4 & & & & 2 & \\
\hline Reticulate Taildropper* & Prophysaon andersoni (MT, ID) & G5 & & & & & & & 1 & & & & & \\
\hline Smokey Taildropper & Prophysaon humile (MT, ID) & G3 & & & & 5 & & & 1 & & 1 & 6 & 1 & 2 \\
\hline Lyre Mantleslug & \begin{tabular}{|l} 
Udosarx lyrata lyrata (MT, ID) \\
\end{tabular} & G2T2 & & & & & & & & & & 2 & & \\
\hline Sheathed Slug & Zacoleus idahoensis (MT, ID) & G3G4 & & & & & & & & & & 5 & 2 & 2 \\
\hline
\end{tabular}

${ }^{a}$ Montana Forests codes: Beaverhead-Deerlodge (B-D), Bitterroot (BI), Custer (CU), Flathead (FL), Gallatin (GA), Helena (HE), Kootenai (KO), Lewis \& Clark (L-C), Lolo (LO).

${ }^{b}$ Idaho Forest codes: Clearwater (CL), Idaho Panhandle (I-P), Nez Perce (N-P). 
As a result of the 2005 surveys, global ranks shifted downward for five species. The Global Rank of Humped Coin changed from G2G3 to G3 (see Appendix A for definitions). The Fir Pinwheel changed from G3 to G4, Pale Jumping-slug changed from G3G4 to G4. The Pygmy Slug changed from G1G2 to G2. The Smoky Taildropper changed from G2 to G3. In summary, the 2005 Northern Region survey made a significant contribution to our understanding of the current status of several land mollusk species of conservation interest.

At least some SOI G4-G5 taxa we found during our 2005 surveys may prove to be distinct from related coastal populations, as their disjunct distributions are similar to some vertebrate amphibian taxa (e.g., Dicamptodon, Ascaphus, Plethodon) now split into coastal and Rocky Mountain sister species. Thus, we think it desirable to conduct genetic analyses of several mollusk SOC and SOI taxa to determine if they represent forms that merit full species status. These will be identified in the species accounts that follow of SOC/SOI taxa encountered during the 2005 survey.

Finally, we recorded 21 additional terrestrial mollusk species (including exotics) as we encountered them during our 2005 surveys. These species are not currently recognized as SOC or SOI, nor are they considered to merit such status, and will not be discussed further in this report. Distribution maps showing locations where we found these taxa are in Appendix F (native NonSOC) and Appendix G (exotic species). Not included in Appendix F is a map showing our two 2005 records of the Chrome Ambersnail (Catinella rehderi) from Carbon and Fergus counties, Montana. Species of Catinella are impossible to identify to species based on shells alone (T. Pearce personal communication), so our identification of shells from these sites remains tentative, and influenced by one prior Montana record from Meagher County (Pilsbry 1948).

\section{Species Accounts}

Selway Forestsnail (Allogona lombardii): We found this species at three Idaho sites between 1600-3700 ft elevation, all in Idaho County
(Appendix B and E). The Selway Forestsnail is an Idaho endemic known only from the LochsaSelway and Lower Salmon corridors of Idaho County (Smith 1943; Frest and Johannes 1997, 2001). Canopy at the 2005 sites included grand fir, western hemlock, and alder; as many as 11 individuals were found on or under bryophyte mats.

Nimapuna Tigersnail (Anguispira nimapuna): We found this species at four Idaho sites between 1500-2550 ft elevation, all in Idaho County (Appendix B and E). The Nimapuna Tigersnail is an Idaho endemic known only from the Clearwater, Lochsa, and Selway rivers drainages (Baker 1932; Smith 1943; Frest and Johannes 1995, 2001). Canopy at the 2005 sites included western redcedar and grand fir, with some alder, paper birch, Douglas-fir and/or ponderosa pine; as many as 10 live animals were found under wood or on bryophyte mats among dense ferns.

Striate Disc (Discus shimeki): We found this species at one Montana site in Gallatin County, at $5832 \mathrm{ft}$ elevation (Appendix B). The Striate Disc has a wide distribution in western North America (Pilsbry 1948; Frest and Johannes 1993; Forsyth 2004) and is ranked G5. It is a Montana SOC because there are less than 10 documented occurrences in the state (see map in Appendix E). Canopy at the 2005 site included Douglas-fir and subalpine fir; two shells were present on a bryophyte mat.

Robust Lancetooth (Haplotrema vancouverense): We found this species at four Idaho sites between 2100-3350 ft elevation, in Bonner, Clearwater, and Shoshone counties (Appendix B and E). The Robust Lancetooth has a wide distribution in the Pacific Coast states and British Columbia (Forsyth 2004) and is ranked G5. It is a new Montana SOC because of only two historical records from Sanders County (Brunson and Osher 1957) and no new records in recent years. Frest and Johannes (2001) listed the Robust Lancetooth as rare and only from northern Idaho. Populations in northern Idaho and northwestern Montana appear disjunct from the main coastal range, and should be examined genetically to determine if they actually are sister species. Canopy at the 2005 sites 
included western redcedar, grand fir, western hemlock, alder, or paper birch; live individuals and shells were found under wood or bryophyte mats.

\section{Berry's Mountainsnail (Oreohelix strigosa} berryi): We found this subspecies at six sites in central Montana between 4250-6400 ft elevation, in Broadwater, Carbon, Fergus, and Meagher counties (Appendix B and E). Berry's Mountainsnail is a narrowly distributed subspecies, largely restricted to central Montana and the Black Hills (Frest and Johannes 1993), of a species that is found throughout western North America (Pilsbry 1939; Forsyth 2004). It is most abundant in the island mountain ranges of central Montana, especially the Big Snowy Mountains (Berry 1916). Canopy at the 2005 sites included aspen, Douglasfir, Engelmann spruce, subalpine fir, cottonwood and maple. Few live animals were found, but hundreds of shells were scattered on and under limestone talus and soil, bryophyte mats, and leaf litter.

Humped Coin (Polygyrella polygyrella): We found this species at six Idaho sites between 1500$3600 \mathrm{ft}$ elevation, in Clearwater and Idaho counties (Appendix B and E). The Humped Coin, first described from Montana and Idaho by Bland and Cooper (1861) and Cooper (1868), is also present in adjacent Washington and Oregon (Frest and Johannes 1995, 2001). In 2005, we found this species only in the Clearwater and Lochsa river drainages, but it is present farther north in Idaho, and all known Montana sites are clustered in Sanders and Mineral counties (Hendricks 2003, 2005). Canopy at the 2005 sites included western redcedar, western hemlock, grand fir, alder, black cottonwood, and mountain maple. Live animals were found at all sites, with as many as 44 found on ferns and bryophyte mats.

Fir Pinwheel (Radiodiscus abietum): We found this species at 11 Idaho sites between $1500-5500 \mathrm{ft}$ elevation, in Bonner, Clearwater, Idaho, and Shoshone counties, and at five sites in Montana between 2200-3450 ft elevation, in Flathead, Lincoln, and Sanders counties (Appendix B and E). The Fir Pinwheel is restricted to northern Idaho, western Montana, and adjacent parts of Oregon and Washington (Brunson and Russell 1967; Frest and Johannes 1995, 2001; Hendricks 2003, 2005). Canopy at the 2005 sites included western redcedar, grand fir, Douglas-fir, western hemlock, subalpine fir, alder, water birch, cottonwood, western larch, and Pacific yew. Up to 11 live individuals were present at 15 sites where they were detected, mostly under downed wood, but also rocks and bryophyte mats. At the remaining site only a single shell was detected.

Pale Jumping-slug (Hemphillia camelus): We found this species at eight Idaho sites between 1600-5100 ft elevation, in Clearwater, Idaho, and Shoshone counties, and at one site in Montana at $2840 \mathrm{ft}$ elevation, in Lincoln County (Appendix B and E). This is the first Montana record for this species (Frest and Johannes 1995; Hendricks 2003) (see Appendix E; Pilsbry 1948; Hendricks 2003). The Pale Jumping-slug appears to be restricted to northern Idaho, and adjacent parts of Washington, British Columbia, Alberta, and now Montana (Frest and Johannes 1995, 2001; Forsyth 2004). Frest and Johannes $(1997,2001)$ suggested that individuals from the Lower Salmon River drainage might represent a taxon distinct from that to the north, but this possibility has not been resolved. Canopy at the 2005 sites included western redcedar, grand fir, subalpine fir, Engelmann spruce, western hemlock, Pacific yew, alder, and birch. Up to six individuals were found on and under downed wood, and on bryophyte mats among ferns and dogwood.

Pygmy Slug (Kootenaia burkei): We found this species at two Idaho sites between 2600-2700 ft elevation, in Bonner and Boundary counties, and at four sites in Montana between 2200-2850 ft elevation, in Lincoln and Sanders counties (Appendix B and E). These are the first Montana records for this species, and more than double the number of total known localities. Only recently was this species described from animals discovered at five Idaho sites. (Leonard et al. 2003). Canopy at the 2005 sites included western redcedar, western hemlock, grand fir, Pacific yew, Douglasfir, paper birch, alder, black cottonwood, western larch, and western white pine. Up to four individuals were found on and under downed wood and bark among leaf litter, and on bryophyte mats. 
Reticulate Taildropper (Prophysaon andersoni): We found this species at one site in Montana at $2200 \mathrm{ft}$ elevation, in Sanders County (Appendix B and $\mathrm{E}$ ). This is the first Montana record for this species. It has rarely been found in northern Idaho (B. Leonard personal communication), and Frest and Johannes (2001) thought it might not be present at all in northern Idaho, despite the tentative records of Smith (1943). This species is widespread in coastal British Columbia, Washington, Oregon, and northern California (Forsyth 2004). Populations in northern Idaho and northwestern Montana appear disjunct from the main coastal range, and should be examined genetically to determine if they actually are sister species. Idaho populations of the congeneric Bluegray Taildropper (P. coeruleum) and Papillose Taildropper ( $P$. dubium) also appear disjunct from the coastal populations (Leonard et al. 2003; Ovaska et al. 2004), and these too deserve genetic comparison to determine their species status; both species are currently ranked G4, and the Reticulate Taildropper is ranked G5 (Table 1). Canopy at the 2005 site included western redcedar, grand fir, black cottonwood, paper birch, and Pacific yew. Two individuals were found under downed wood.

Smoky Taildropper (Prophysaon humile): We found this species at nine sites in Idaho between 1500-4250 ft elevation, in Bonner, Clearwater, and Idaho counties, and at seven sites in Montana between 2800-4150 ft elevation, in Flathead, Lincoln, and Missoula counties (Appendix B and E). This species is known only from northern Idaho and adjacent northwestern Montana (Pilsbry
1948; Frest and Johannes 1995, 2001; Hendricks 2005). Canopy at the 2005 sites included western redcedar, grand fir, Douglas-fir, Engelmann spruce, subalpine fir, lodgepole pine, western hemlock, alder, paper birch, and cottonwood. Up to nine individuals were found mostly under downed wood, bryophyte mats, or rocks.

Lyre Mantleslug (Udosarx lyrata): We found this species at two Idaho sites between 2100-3600 ft elevation, in Clearwater and Idaho counties (Appendix B and E). This species is restricted to northern Idaho and adjacent parts of western Montana (Webb 1959; Russell and Webb 1980; Frest and Johannes 1995, 2001; Hendricks 2003). Two subspecies are described, but we are unable to distinguish these and assign our records only to the species level. Canopy at the 2005 sites included western redcedar, grand fir, and alder. Up to four individuals were found under downed wood and wet bark.

Sheathed Slug (Zacoleus idahoensis): We found this species at nine Idaho sites between 2000-5500 ft elevation, in Bonner, Clearwater, and Idaho counties (Appendix B and E). This species is restricted to northern Idaho and adjacent northwestern Montana (Pilsbry 1948; Frest and Johannes 1995, 2001; Hendricks 2003). Canopy at the 2005 sites included western redcedar, grand fir, western hemlock, Douglas-fir, Engelmann spruce, subalpine fir, alder, and paper birch. Up to 11 individuals were found under wet downed wood or on bryophyte mats. 


\section{Conclusions ANd Recommendations}

The number of new locations we discovered in 2005 for land mollusk species of conservation concern in the USFS Northern Region area underscores our conclusion that current knowledge of the distribution, ecology, and status of this suite of species is woefully inadequate and largely fragmentary. We think at least one additional year of non-random surveys, similar to those of 2005, is needed to fill distribution gaps and gather additional habitat information. We also feel that a minimum of two additional years of random site surveys (beyond the one of non-random surveys) are needed in order to fully document species distributions and habitat associations and to determine site occupancy rates, while addressing detection probabilities. This will provide a measure of status in various habitats. Developing predictive habitat models may also prove useful for some species groups, especially those associated with the moist forest types mentioned earlier. Recent examples of the use of predictive models for conservation management of rare terrestrial mollusks in the Pacific Northwest are Dunk et al. (2004) and Gaines et al. (2005).

Other recommendations include the following: (1) Survey and modeling efforts should be coordinated with the Idaho CDC, as well as MTNHP, as the Idaho CDC expertise with the Idaho land mollusk fauna exceeds ours; (2) There is a need for genetic studies to inform current taxonomy of some species. We think some taxa currently considered conspecific with coastal populations (e.g., Robust Lancetooth, Reticulate Taildropper, Blue-gray Taildropper, and Papillose Taildropper) may prove to be distinct sister species (see discussions in Leonard et al. 2003, Ovaska et al. 2004), similar to the results of recent genetic studies of some Pacific Northwest amphibian genera (e.g., Ascaphus, Dicamptodon, Plethodon); (3) Finally, we think it would be useful to conduct some workshops on land mollusk identification and management. This will heighten awareness of this overlooked and poorly understood group of animals, and provide biologists and managers some of the basic tools they need to make informed management decisions.

Besides producing this summary document for the 2005 inventory, we anticipate developing an illustrated field guide and/or poster that will aid District Biologists in future survey work they conduct targeting SOC and SOI land mollusks; similar information and illustrations for Montana species will be made available in the near future in the Montana Natural Heritage Program on-line Animal Field Guide. 


\section{References Cited}

Baker, H. B. 1932. New land snails from Idaho and eastern Oregon. The Nautilus 45:8287.

Berry, S. S. 1916. Notes on mollusca of central Montana. The Nautilus 29:124-128.

Bland, T., and J. G. Cooper. 1861. Notice of land and freshwater shells collected by Dr. J. G. Cooper in the Rocky Mountains, etc., in 1860. Annals of the Lyceum of Natural History of New York 7:362-370.

Brunson, R. B., and U. Osher. 1957. Haplotrema from western Montana. The Nautilus 70:121-123.

Brunson, R. B., and R. H. Russell. 1967. Radiodiscus, new to molluscan fauna of Montana. The Nautilus 81:18-22.

CFR (Code of Federal Regulations). 1985. 36 Code of Federal Regulations. Chapter II 219.19:64.

Cooper, J. G. 1868. The shells of Montana. American Naturalist 2:486-487.

Dunk, J. R., W. J. Zielinski, and H. K. Preisler. 2004. Predicting the occurrence of rare mollusks in northern California forests. Ecological Applications 14:713-729.

Fairbanks, H. L. 1984. A new species of Oreohelix (Gastropoda: Pulmonata: Oreohelicidae) from the Seven Devils Mountains, Idaho. Proceedings of the Biological Society of Washington 97:179185.

Forsyth, R. G. 2004. Land snails of British Columbia. Royal British Columbia Museum, Victoria, BC. 188 pp.
Frest, T. J., and E. J. Johannes. 1993. Land snail survey of the Black Hills National Forest, South Dakota and Wyoming. Final report to USDA Forest Service, Black Hills National Forest and USDI Fish \& Wildlife Service, South Dakota State Office. 156 pp. + appendices.

Frest, T. J., and E. J. Johannes. 1995. Interior Columbia Basin mollusk species of special concern. Final Report to Interior Columbia Basin Ecosystem Management Project. Deixis Consultants, Seattle. 274 pp.

Frest, T. J., and E. J. Johannes. 1997. Land snail survey of the lower Salmon River drainage, Idaho. Idaho Bureau of Land Management Technical Bulletin No. 97-18.

Frest, T. J., and E. J. Johannes. 2001. An annotated checklist of Idaho land and freshwater mollusks. Journal of the Idaho Academy of Science 36:1-51.

Gaines, W. L., A. L. Lyons, and A. Sprague. 2005. Predicting the occurrence of a rare mollusk in the dry forests of north-central Washington. Northwest Science 79:99105.

Hendricks, P. 1998. Rediscovery of Discus brunsoni Berry, 1955 and Oreohelix alpina (Elrod, 1901) in the Mission Mountains, Montana, with comments on Oreohelix elrodi (Pilsbry, 1900). The Nautilus 112:58-62.

Hendricks, P. 2003. Status and conservation management of terrestrial mollusks of Special Concern in Montana. Report to Region 1, U.S. Forest Service. Montana Natural Heritage Program, Helena, MT. 67 pp. + appendices. 
Hendricks, P., Compiler. 2005. Surveys for Animal Species of Concern in northwestern Montana. Report to Montana Department of Fish, Wildlife, and Parks, State Wildlife Grants Program, Helena, Montana. Montana Natural Heritage Program, Helena, MT. 53 pp.

Leonard, W. P., L. Chichester, J. Baugh, and T. Wilke. 2003. Kootenaia burkei, a new genus and species of slug from northern Idaho, United States (Gastropoda: Pulmonata: Arionidae). Zootaxa 355:1-16.

Leonard, W. P., L. Chichester, and K. Ovaska. 2003. Prophysaon dubium Cockerell, 1890, the papillose taildropper (Gastropoda: Arionidae): distribution and anatomy. The Nautilus 117:62-67.

Ovaska, K., W. P. Leonard, L. Chichester, T. E. Burke, L. Sopuck, and J. Baugh. 2004. Prophysaon coeruleum Cockerell, 1890, blue-gray taildropper (Gastropoda: Arionidae): new distributional records and reproductive anatomy. Western North American Naturalist 64:538-543.

Pilsbry, H. A. 1939. Land mollusca of North America (north of Mexico), Volume I Part 1. The Academy of Natural Sciences of Philadelphia Monographs Number 3 (1):1573.

Pilsbry, H. A. 1948. Land mollusca of North America (north of Mexico), Volume II Part 2. The Academy of Natural Sciences of Philadelphia Monographs Number 3 (2):521-1113.

Russell, R. H., and G. R. Webb. 1980. The slug Udosarx lyrata: additional data on distribution, anatomy, and taxonomy. Gastropodia 2:8-10.

Solem, A. 1975. Notes on Salmon River Valley oreohelicid land snails, with description of Oreohelix waltoni. The Veliger 18:16-30.
Smith, A. G. 1943. Mollusks of the Clearwater Mountains, Idaho. Proceedings of the California Academy of Sciences, fourth series, 23:537-554.

Webb, G. R. 1959. Two new north-western slugs, Udosarx lyrata and Gliabates oregonia. Gastropodia 1(3):22-23, 28. 



\section{Appendix A. Global/State Rank Definitions}





\section{Heritage Program Ranks}

The international network of Natural Heritage Programs employs a standardized ranking system to denote global (range-wide) and state status. Species are assigned numeric ranks ranging from 1 to 5, reflecting the relative degree to which they are "at-risk". Rank definitions are given below. A number of factors are considered in assigning ranks - the number, size and distribution of known "occurrences" or populations, population trends (if known), habitat sensitivity, and threat. Factors in a species' life history that make it especially vulnerable are also considered (e.g., dependence on a specific pollinator).

Global Rank Definitions (NatureServe 2003)

G1 Critically imperiled because of extreme rarity and/or other factors making it highly vulnerable to extinction

G2 Imperiled because of rarity and/or other factors making it vulnerable to extinction

G3 Vulnerable because of rarity or restricted range and/or other factors, even though it may be abundant at some of its locations

G4 Apparently secure, though it may be quite rare in parts of its range, especially at the periphery

G5 Demonstrably secure, though it may be quite rare in parts of its range, especially at the periphery

T1-5 Infraspecific Taxon (trinomial) - The status of infraspecific taxa (subspecies or varieties) are indicated by a "T-rank" following the species' global rank

\section{State Rank Definitions}

S1

S2

S3

S4

S5

At high risk because of extremely limited and potentially declining numbers, extent and/or habitat, making it highly vulnerable to extirpation in the state At risk because of very limited and potentially declining numbers, extent and/or habitat, making it vulnerable to extirpation in the state

S3 Potentially at risk because of limited and potentially declining numbers, extent and/or habitat, even though it may be abundant in some areas

S4 Uncommon but not rare (although it may be rare in parts of its range), and usually widespread. Apparently not vulnerable in most of its range, but possibly cause for long-term concern Common, widespread, and abundant (although it may be rare in parts of its range). Not vulnerable in most of its range

\section{COMBination RANKS}

G\#G\# or S\#S\# Range Rank-A numeric range rank (e.g., G2G3) used to indicate uncertainty about the exact status of a taxon

\section{QUALIFIERS}

NR

Not ranked

Questionable taxonomy that may reduce conservation priority-Distinctiveness of this entity as a taxon at the current level is questionable; resolution of this uncertainty may result in change from a species to a subspecies or hybrid, or inclusion of this taxon in another taxon, with the resulting taxon having a lower-priority (numerically higher) conservation status rank 
Presumed Extinct-Species believed to be extinct throughout its range. Not located despite intensive searches of historical sites and other appropriate habitat, and virtually no likelihood that it will be rediscovered

H Possibly Extinct-Species known from only historical occurrences, but may never-theless still be extant; further searching needed

Unrankable - Species currently unrankable due to lack of information or due to substantially conflicting information about status or trends

HYB Hybrid-Entity not ranked because it represents an interspecific hybrid and not a species

Inexact Numeric Rank-Denotes inexact numeric rank

$\mathrm{C}$

Captive or Cultivated Only-Species at present is extant only in captivity or cultivation, or as a reintroduced population not yet established

Accidental-Species is accidental or casual in Montana, in other words, infrequent and outside usual range. Includes species (usually birds or butterflies) recorded once or only a few times at a location. A few of these species may have bred on the one or two occasions they were recorded

Z Zero Occurrences-Species is present but lacking practical conservation concern in Montana because there are no definable occurrences, although the taxon is native and appears regularly in Montana

Potential-Potential that species occurs in Montana but no extant or historic occurrences are accepted

R Reported-Species reported in Montana but without a basis for either accepting or rejecting the report, or the report not yet reviewed locally. Some of these are very recent discoveries for which the program has not yet received first-hand information; others are old, obscure reports

SYN Synonym - Species reported as occurring in Montana, but the Montana Natural Heritage Program does not recognize the taxon; therefore the species is not assigned a rank

A rank has been assigned and is under review. Contact the Montana Natural Heritage Program for assigned rank

B Breeding - Rank refers to the breeding population of the species in Montana 


\section{Appendix B. USFS Region 1 Survey Sites for Land Mollusks IN 2005}





\begin{tabular}{|c|c|c|c|c|c|c|c|}
\hline Forest $^{\mathrm{a}}$ & State & 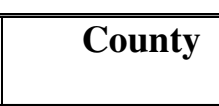 & $\begin{array}{c}\text { UTM } \\
\text { NAD 27 }\end{array}$ & Site Name & $\begin{array}{c}\text { Elev } \\
\text { (ft) }\end{array}$ & Date & SOC/SOI Taxa $^{\mathbf{b}}$ \\
\hline$\overline{\text { B-D }}$ & MT & Madison & 12: 433652E 5032978N & Daisy Creek & 6221 & 6 Oct & \\
\hline B-D & MT & Madison & 12: 433327E 5033290N & Daisy Creek & 6387 & $6 \mathrm{Oct}$ & \\
\hline B-D & MT & Madison & 12: 431197E 5042579N & N Meadow Creek & 6622 & 6 Oct & \\
\hline B-D & MT & Madison & 12: 431390E 5051347N & Willow Creek & 5723 & 6 Oct & \\
\hline B-D & MT & Madison & 12: 456430E 5000257N & Sphinx Mountain C.G. & 6195 & 7 Oct & \\
\hline B-D & MT & Madison & 12: 456481E 4993881N & Indian Creek & 6210 & 7 Oct & \\
\hline B-D & MT & Madison & 12: 455242E 4971846N & Papoose Creek trail & 6311 & 7 Oct & \\
\hline B-D & MT & Madison & $12: 453811 \mathrm{E} 4970009 \mathrm{~N}$ & Gazette Creek & 6000 & 7 Oct & \\
\hline B-D & MT & Beaverhead & 12: 334379E 5051791N & Lacy Creek & 6693 & 20 Oct & \\
\hline B-D & MT & Beaverhead & 12: 353401E 5032771N & Birch Creek Rd & 6950 & 20 Oct & \\
\hline B-D & MT & Madison & 12: 421598E 4967721N & Basin Creek, Ruby River Rd & 6946 & 21 Oct & \\
\hline B-D & MT & Madison & 12: 421796E 4974062N & opposite Dos Creek & 6723 & $21 \mathrm{Oct}$ & \\
\hline B-D & MT & Madison & 12: 422342E $4976048 \mathrm{~N}$ & Dry Fawn Creek & 6646 & 21 Oct & \\
\hline B-D & MT & Madison & 12: 423738E 4981384N & Short Creek & 6353 & 21 Oct & \\
\hline CL & ID & Clearwater & 11: 644430E 5188837N & N. Fork Clearwater River & 3540 & 22 Sep & Raab \\
\hline CL & ID & Clearwater & 11: 643771E 5187848N & Deception Gulch & 3700 & 22 Sep & Raab \\
\hline $\mathrm{CL}$ & ID & Clearwater & 11: 630784E 5175677N & N. Fork Clearwater River & 2745 & 22 Sep & Popo, Prhu \\
\hline $\mathrm{CL}$ & ID & Clearwater & 11: 616029E 5181048N & N. Fork Clearwater River & 2000 & 22 Sep & $\begin{array}{l}\text { Heca, Prhu, Raab, } \\
\text { Zaid }\end{array}$ \\
\hline $\mathrm{CL}$ & ID & Clearwater & 11: 618442E 5189072N & Skull Creek & 2125 & 23 Sep & Hava, Prhu, Udly \\
\hline CL & ID & Clearwater & 11: 610464E 5173214N & $\begin{array}{l}\text { Washington Creek } \\
\text { Campground }\end{array}$ & 2100 & 23 Sep & $\begin{array}{l}\text { Hava, Prhu, Raab, } \\
\text { Zaid }\end{array}$ \\
\hline $\mathrm{CL}$ & ID & Clearwater & 11: 606286E 5109880N & Wild Goose Campground & 1500 & 29 Sep & $\begin{array}{l}\text { Anni, Popo, Prhu, } \\
\text { Raab }\end{array}$ \\
\hline CL & ID & Clearwater & 11: 684222E 5163577N & Lolo Pass & 4570 & $30 \mathrm{Sep}$ & Heca \\
\hline CL & ID & Clearwater & 11: 678297E 5156289N & DeVoto Memorial Grove & 3590 & $30 \mathrm{Sep}$ & $\begin{array}{l}\text { Popo, Prhu, Udly, } \\
\text { Zaid }\end{array}$ \\
\hline $\mathrm{CL}$ & ID & Clearwater & 11: 685846E 5164927N & Pack Creek, Lolo Pass & 5160 & 30 Sep & Zaid \\
\hline $\mathrm{CL}$ & ID & Clearwater & 11: 691799E 5166331N & Cascade above Brushy Fork & 5500 & $6 \mathrm{Oct}$ & Raab, Zaid \\
\hline $\mathrm{CU}$ & MT & Carbon & $12: 633364 \mathrm{E} 5003082 \mathrm{~N}$ & Palisades Campground & 6312 & 5 Oct & \\
\hline $\mathrm{CU}$ & MT & Carbon & 12: 628574E 5001261N & Washoe Creek & 6717 & 10 Oct & \\
\hline
\end{tabular}




\begin{tabular}{|c|c|c|c|c|c|c|c|}
\hline Forest $^{\text {a }}$ & State & County & $\begin{array}{c}\text { UTM } \\
\text { NAD } 27\end{array}$ & Site Name & $\begin{array}{c}\text { Elev } \\
\text { (ft) }\end{array}$ & Date & SOC/SOI Taxa $^{\mathbf{b}}$ \\
\hline $\mathrm{CU}$ & $\overline{\mathrm{MT}}$ & Carbon & 12: 632079E 4993907N & Ratine Campground & 6388 & 11 Oct & Osbe \\
\hline $\mathrm{CU}$ & MT & Carbon & 12: $623046 \mathrm{E} 4987040 \mathrm{~N}$ & Rock Creek road & 7552 & $11 \mathrm{Oct}$ & \\
\hline $\mathrm{CU}$ & MT & Carbon & 12: $698445 \mathrm{E} 5006938 \mathrm{~N}$ & Trappers Cabin Spring & 6674 & 11 Oct & \\
\hline $\mathrm{CU}$ & MT & Carbon & 12: 693394E 5009266N & Sage Creek & 5732 & 11 Oct & \\
\hline $\mathrm{CU}$ & MT & Carbon & 12: 701129E 5005597N & Crooked Creek & 7171 & 12 Oct & Care \\
\hline $\mathrm{CU}$ & MT & Carbon & 12: 700432E 5006043N & Tie Flat & 7087 & 12 Oct & \\
\hline FL & MT & Flathead & 12: 302229E 5323477N & N. Fork Clark Creek & 3820 & 20 Oct & Prhu \\
\hline FL & MT & Flathead & 12: 292962E 5333194N & Graves Bay & 3750 & 20 Oct & Prhu \\
\hline FL & MT & Flathead & 11: $719845 \mathrm{E} 5361343 \mathrm{~N}$ & Whelp Creek, at Lion Lake & 3440 & 20 Oct & Prhu \\
\hline FL & MT & Flathead & 12: 306742E 5349804N & Walton & 3780 & $21 \mathrm{Oct}$ & \\
\hline FL & MT & Flathead & 12: 285169E 5374870N & Kootenai Creek & 3440 & 21 Oct & Prhu, Raab \\
\hline FL & MT & Flathead & 11: 714612E 5363026N & Badrock Canyon & 3050 & 21 Oct & Prhu \\
\hline FL & MT & Flathead & 11: 712272E 5375118N & Glacier Rim river access & 3180 & 25 Oct & \\
\hline FL & MT & Flathead & 11: 697962E 5382199N & Big Creek & 4140 & 25 Oct & \\
\hline FL & MT & Flathead & 11: 688922E 5409241N & Red Meadow Creek & 4240 & 26 Oct & \\
\hline GA & MT & Meagher & 12: 536538E 5119371N & Smith Creek & 6257 & $1 \mathrm{Oct}$ & \\
\hline GA & MT & Meagher & 12: $548915 \mathrm{E} 5115237 \mathrm{~N}$ & Dugout Creek & 6971 & $1 \mathrm{Oct}$ & \\
\hline GA & MT & Meagher & $12: 550001 \mathrm{E} 5114296 \mathrm{~N}$ & Lodgepole Creek & 6700 & $1 \mathrm{Oct}$ & \\
\hline GA & MT & Meagher & 12: 543965E 5112874N & Deep Creek & 6456 & 1 Oct & \\
\hline GA & MT & Meagher & $12: 544502 \mathrm{E} 5124436 \mathrm{~N}$ & Castle Creek & 6039 & 1 Oct & \\
\hline GA & MT & Park & 12: 537684E 5038151N & Pine Creek trailhead & 5668 & 4 Oct & \\
\hline GA & MT & Park & 12: 537107E 5014922N & Mill Creek & 5688 & 5 Oct & \\
\hline GA & MT & Sweetgrass & 12: 562854E 5033683N & Aspen Campground & 5407 & 12 Oct & \\
\hline GA & MT & Sweetgrass & 12: 561089E 5037507N & Falls Creek Campground & 5242 & 12 Oct & \\
\hline GA & MT & Gallatin & 12: 482099E 5013744N & Dudley Creek, along Hwy 191 & 5946 & 13 Oct & \\
\hline GA & MT & Gallatin & 12: 483550E 5015692N & Goose Creek & 5987 & 13 Oct & \\
\hline GA & MT & Gallatin & 12: 484959E 5031594N & Spire Rock Campground & 5832 & 13 Oct & Dish \\
\hline GA & MT & Gallatin & 12: 499497E 5042474N & Moser Creek & 6310 & 13 Oct & \\
\hline GA & MT & Gallatin & $12: 503346 \mathrm{E} 5090109 \mathrm{~N}$ & road to Flathead Pass & 6323 & 14 Oct & \\
\hline GA & MT & Gallatin & $12: 506564 \mathrm{E} 5084007 \mathrm{~N}$ & Fairy Creek & 6549 & 14 Oct & \\
\hline GA & MT & Gallatin & 12: 508149E 5081951N & Cache Creek & 6192 & 14 Oct & \\
\hline
\end{tabular}




\begin{tabular}{|c|c|c|c|c|c|c|c|}
\hline Forest $^{\mathrm{a}}$ & State & County & $\begin{array}{c}\text { UTM } \\
\text { NAD } 27 \\
\end{array}$ & Site Name & $\begin{array}{c}\text { Elev } \\
(\mathrm{ft})\end{array}$ & Date & SOC/SOI Taxa \\
\hline $\mathrm{HE}$ & MT & Meagher & 12: 492933E 5129289N & Battle Mountain Road & 6380 & 19 Sep & \\
\hline $\mathrm{HE}$ & MT & Broadwater & 12: 488119E 5132001N & Deep Creek & 5080 & 19 Sep & \\
\hline $\mathrm{HE}$ & MT & Broadwater & 12: 457104E 5164506N & Avalanche Creek & 4268 & 19 Sep & Osbe \\
\hline $\mathrm{HE}$ & MT & Jefferson & 12: 435798E 5147472N & Crystal Creek & 5224 & 27 Sep & \\
\hline $\mathrm{HE}$ & MT & Jefferson & 12: 428271E 5141122N & Warm Springs Creek & 4680 & 27 Sep & \\
\hline $\mathrm{HE}$ & MT & \begin{tabular}{|l|} 
Broadwater \\
\end{tabular} & 12: 446064E 5142057N & Weasel Creek & 5390 & 27 Sep & \\
\hline $\mathrm{HE}$ & MT & Lewis \& Clark & 12: 449455E 5187615N & Beaver Creek & 6274 & 30 Sep & \\
\hline $\mathrm{HE}$ & MT & Lewis \& Clark & 12: 446328E 5189656N & Beaver Creek & 4809 & $30 \mathrm{Sep}$ & \\
\hline $\mathrm{HE}$ & MT & Lewis \& Clark & 12: 440972E 5177782N & Nelson Road & 4311 & $30 \mathrm{Sep}$ & \\
\hline $\mathrm{HE}$ & MT & Lewis \& Clark & 12: 386784E 5180761N & S. Fork Little Prickly Pear Cr. & 5240 & 5 Oct & \\
\hline $\mathrm{HE}$ & MT & Lewis \& Clark & 12: 387145E 5181566N & Bear Trap Gulch & 5100 & $5 \mathrm{Oct}$ & \\
\hline $\mathrm{HE}$ & MT & Lewis \& Clark & 12: 381909E 5192006N & Poorman Creek & 5320 & $5 \mathrm{Oct}$ & \\
\hline $\mathrm{HE}$ & MT & Lewis \& Clark & 12: 379065E 5192491N & Poorman Creek & 5000 & 5 Oct & \\
\hline $\mathrm{I}-\mathrm{P}$ & ID & Bonner & 11: 565950E 5341771N & Lightening Creek & 2610 & 27 Oct & $\begin{array}{l}\text { Hava, Kobu, Prhu, } \\
\text { Raab, Zaid }\end{array}$ \\
\hline $\mathrm{I}-\mathrm{P}$ & ID & Shoshone & 11: 588051E 5284451N & $\begin{array}{l}\text { West Fork Eagle Creek } \\
\text { (Settlers Cedar Grove) }\end{array}$ & 3320 & 27 Oct & Hava, Heca, Raab \\
\hline $\mathrm{I}-\mathrm{P}$ & ID & Boundary & 11: 562646E 5407425N & Meadow Creek Campground & 2310 & 4 Nov & Zaid \\
\hline $\mathrm{I}-\mathrm{P}$ & ID & Boundary & 11: 541530E 5390916N & Snow Creek & 2685 & 4 Nov & Kobu \\
\hline KO & MT & Lincoln & 11: 624604E 5398084N & Peck Gulch and Landing & 2480 & 26 Oct & \\
\hline KO & MT & Lincoln & 11: 580694E 5339821N & Ross Creek Cedar Grove & 2840 & 26 Oct & Kobu, Prhu, Raab \\
\hline KO & MT & Lincoln & 11: 582176E 5388329N & Yaak Falls Campground & 2400 & $3 \mathrm{Nov}$ & Kobu, Raab \\
\hline KO & MT & Lincoln & 11: 579587E 5401244N & Red Top Campground & 2840 & 3 Nov & Heca, Kobu, Raab \\
\hline $\mathrm{KO}$ & MT & Sanders & 11: 580446E 5324068N & Big Eddy Campground & 2200 & 4 Nov & Kobu, Pran, Raab \\
\hline $\mathrm{L}-\mathrm{C}$ & MT & Meagher & 12: 543825E 5128430N & Deer Creek & 6174 & 29 Sep & \\
\hline $\mathrm{L}-\mathrm{C}$ & MT & Chouteau & 12: 531512E 5257173N & N. Fork Highwood Creek & 4577 & 29 Sep & \\
\hline L-C & MT & Cascade & 12: 514564E 5215409N & Dry Fork & 4680 & 29 Sep & \\
\hline L-C & MT & Meagher & 12: 543825E 5128430N & tributary to Cottonwood Creek & 6174 & $1 \mathrm{Oct}$ & \\
\hline $\mathrm{L}-\mathrm{C}$ & MT & Golden Valley & 12: 651613E 5177625N & Minerva Creek & 4910 & 2 Oct & \\
\hline $\mathrm{L}-\mathrm{C}$ & MT & Fergus & 12: 648557E 5179128N & Pole Creek & 4955 & 2 Oct & Care, Osbe \\
\hline $\mathrm{L}-\mathrm{C}$ & MT & Fergus & 12: 613571E 5183942N & Crystal Lake Campground & 6109 & 2 Oct & Osbe \\
\hline
\end{tabular}




\begin{tabular}{|c|c|c|c|c|c|c|c|}
\hline Forest $^{\mathrm{a}}$ & State & County & $\begin{array}{c}\text { UTM } \\
\text { NAD 27 }\end{array}$ & Site Name & $\begin{array}{c}\text { Elev } \\
(f t)\end{array}$ & Date & $\mathrm{PSOC} /$ SOI Taxa $^{\mathbf{b}}$ \\
\hline L-C & MT & Fergus & 12: 613661E 5189516N & Big Rock Creek & 5204 & 2 Oct & Osbe \\
\hline L-C & MT & Meagher & 12: 540971E 5162557N & Spring Creek & 5431 & 4 Oct & \\
\hline L-C & MT & Meagher & 12: 541887E 5155849N & Spring Creek & 5195 & 4 Oct & Osbe \\
\hline L-C & MT & Meagher & 12: 508385E 5184971N & Moose Creek & 5707 & 4 Oct & \\
\hline L-C & MT & Meagher & 12: 520377E 5154218N & Fourmile Creek & 5850 & 4 Oct & \\
\hline $\mathrm{L}-\mathrm{C}$ & MT & Meagher & 12: 523595E 5152921N & headwaters of Fourmile Creek & 6371 & 4 Oct & \\
\hline L-C & MT & Meagher & 12: 531387E 5155015N & headwaters of Brooks Creek & 5987 & 4 Oct & \\
\hline L-C & MT & Teton & 12: 372728E 5304951N & Clary Coulee, near Wind Mtn & 5160 & 6 Oct & \\
\hline L-C & MT & Teton & 12: 371077E 5306593N & N. Fork Teton River & 5200 & 6 Oct & \\
\hline L-C & MT & Lewis \& Clark & 12: 368275E 5273593N & $\begin{array}{l}\text { confluence of Beaver Creek } \\
\text { and N. Fork Sun River }\end{array}$ & 4580 & 6 Oct & \\
\hline L-C & MT & Lewis \& Clark & 12: 370616E 5274776N & N. Fork Sun River C.G. & 4480 & 6 Oct & \\
\hline LO & MT & Missoula & 12: 276255E 5199886N & Woods Gulch & 4150 & 5 Oct & Prhu \\
\hline $\mathrm{N}-\mathrm{P}$ & ID & Idaho & 11: 565439E 5037059N & Allison Creek & 3640 & 27 Sep & Allo, Zaid \\
\hline $\mathrm{N}-\mathrm{P}$ & ID & Idaho & 11: 571344E 5078279N & $\begin{array}{l}\text { Fish Creek Meadow } \\
\text { Campground }\end{array}$ & 5060 & 27 Sep & Heca \\
\hline $\mathrm{N}-\mathrm{P}$ & ID & Idaho & 11: 582828E 5075274N & Mill Creek & 2370 & 28 Sep & Allo, Popo \\
\hline $\mathrm{N}-\mathrm{P}$ & ID & Idaho & 11: 586708E 5074957N & Johns Creek trailhead & 2525 & $28 \mathrm{Sep}$ & $\begin{array}{l}\text { Anni, Heca, Popo, } \\
\text { Prhu, Raab, Zaid }\end{array}$ \\
\hline $\mathrm{N}-\mathrm{P}$ & ID & Idaho & 11: 601568E 5072831N & Rainy Day Creek & 3445 & $28 \mathrm{Sep}$ & Heca \\
\hline $\mathrm{N}-\mathrm{P}$ & ID & Idaho & 11: 620257E 5083623N & American River Campground & 4250 & 28 Sep & Heca, Prhu \\
\hline $\mathrm{N}-\mathrm{P}$ & ID & Idaho & 11: 580307E 5075362N & Castle Creek & 2300 & 28 Sep & Anni, Raab \\
\hline $\mathrm{N}-\mathrm{P}$ & ID & Idaho & 11: $614631 \mathrm{E} 5103162 \mathrm{~N}$ & O’Hara Creek & 1640 & 29 Sep & $\begin{array}{l}\text { Allo, Anni, Heca, } \\
\text { Popo, Raab }\end{array}$ \\
\hline
\end{tabular}

${ }^{a}$ National Forests: B-D (Beaverhead-Deerlodge), CL (Clearwater), CU (Custer), FL (Flathead), GA (Gallatin), HE (Helena), I-P (Idaho Panhandle), KO (Kootenai), L-C (Lewis and Clark), LO (Lolo), N-P (Nez Perce).

${ }^{\mathrm{b}}$ SOC/SOI taxa codes: Allo (Selway Forestsnail, Allogona lombardii), Anni (Nimapuna Tigersnail, Anguispira nimapuna), Care (Chrome Ambersnail, Catinella rehderi), Dish (Striate Disc, Discus shimekii), Hava (Robust Lancetooth, Haplotrema vancouverense), Heca (Pale Jumping-slug, Hemphillia camelus), Kobu (Pygmy Slug, Kootenai burkei), Osbe (Berry's Mountainsnail, Oreohelix strigosa berryi), Popo (Humped Coin, Polygyrella polygyrella), Pran (Reticulate Taildropper, Prophysaon andersoni), Prhu (Smokey Taildropper, Prophysaon humile), Raab (Fir Pinwheel, Radiodiscus abietum), Udly (Lyre Mantleslug, Udosarx lyrata), Zaid (Sheathed Slug, Zacoleus idahoensis). 
Appendix C. Standardized Data Sheets 



\section{Data Form for Terrestrial Mollusk Site Surveys \\ Locality Information}

\begin{tabular}{|c|c|c|c|c|c|c|c|c|}
\hline Ecoregion: & Sample Block: & Site No & Locality: & & & & & \\
\hline State: & County: & $\begin{array}{l}1 \\
1\end{array}$ & & & $\mathrm{~T}$ & $\mathrm{R}$ & $\mathrm{S}$ & \begin{tabular}{l|l} 
Section & Description: \\
\end{tabular} \\
\hline Owner: & \begin{tabular}{l|l} 
Map \\
Elevation:
\end{tabular} & FT & Datum: & $\begin{array}{l}\text { UTM } \\
\text { Zone: }\end{array}$ & & & & $\begin{array}{l}\text { UTM } \\
\text { North: }\end{array}$ \\
\hline
\end{tabular}

\section{Habitat Information}

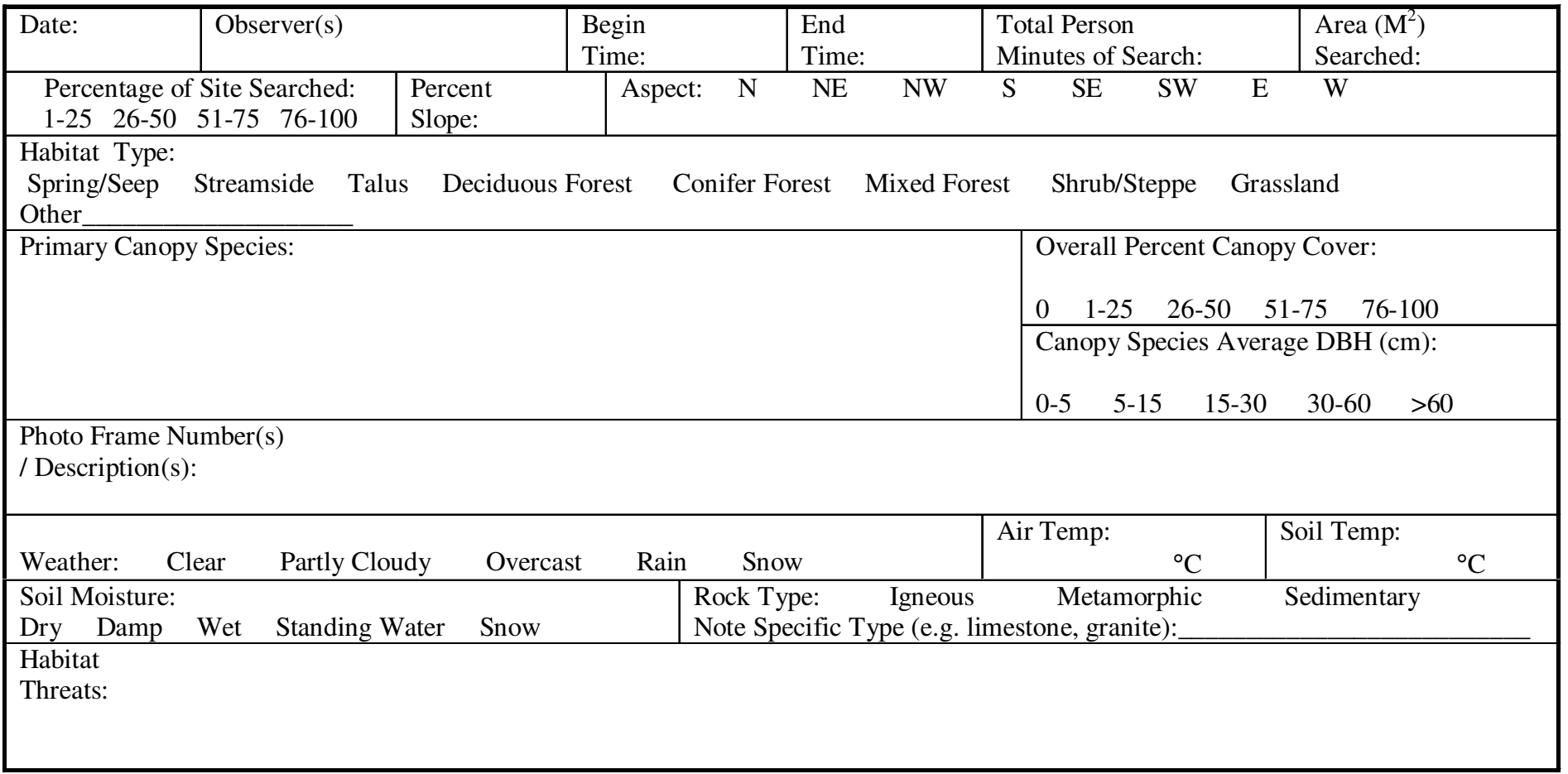

\section{Mollusk Species Information}

\begin{tabular}{|l|l|}
\hline Species: & Number Alive and/or Dead, Size, and Time at First Detection (e.g., 2 alive \& 4 dead x 15mm Diameter or TL @ 10 minutes)
\end{tabular}

\begin{tabular}{l|l}
\hline Tissue Number (e.g., H001A) & Substrate Association (Circle):
\end{tabular}

Voucher Number under wood under $4-20 \mathrm{~cm}$ rock fragments under $>20 \mathrm{~cm}$ rock fragments \& Description: under bryophyte mat on bryophyte mat in rock fracture Other

\begin{tabular}{l|l}
\hline Species: & Number Alive and/or Dead, Size, and Time at First Detection (e.g., 2 alive \& 4 dead x 15mm Diameter or TL @ 10 minutes)
\end{tabular}

Tissue Number (e.g., H001A)

Voucher Number

\& Description:

Species:

\section{Substrate Association (Circle):}

under wood under $4-20 \mathrm{~cm}$ rock fragments under $>20 \mathrm{~cm}$ rock fragments under bryophyte mat on bryophyte mat in rock fracture Other

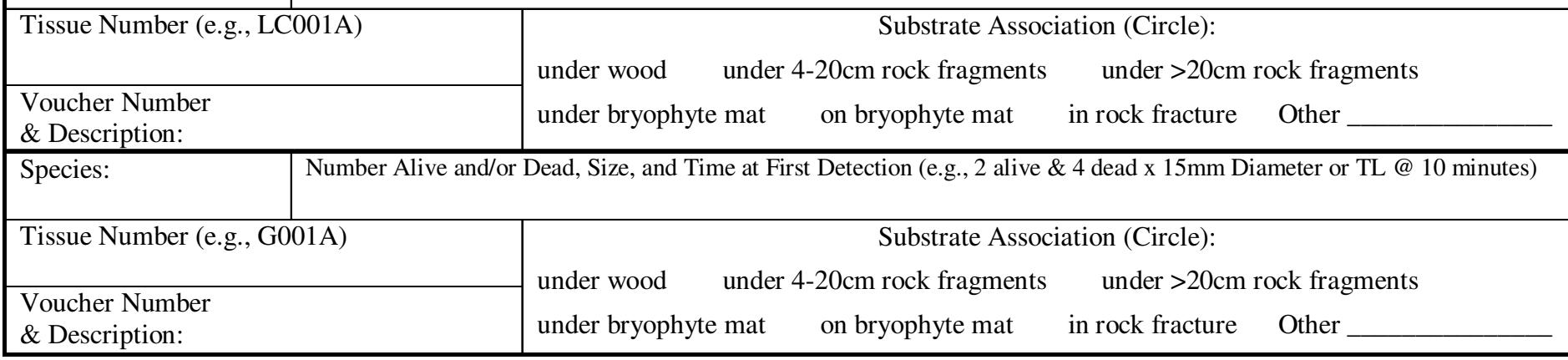


Grid Scale:

Site Map for Terrestrial Mollusk Site Surveys

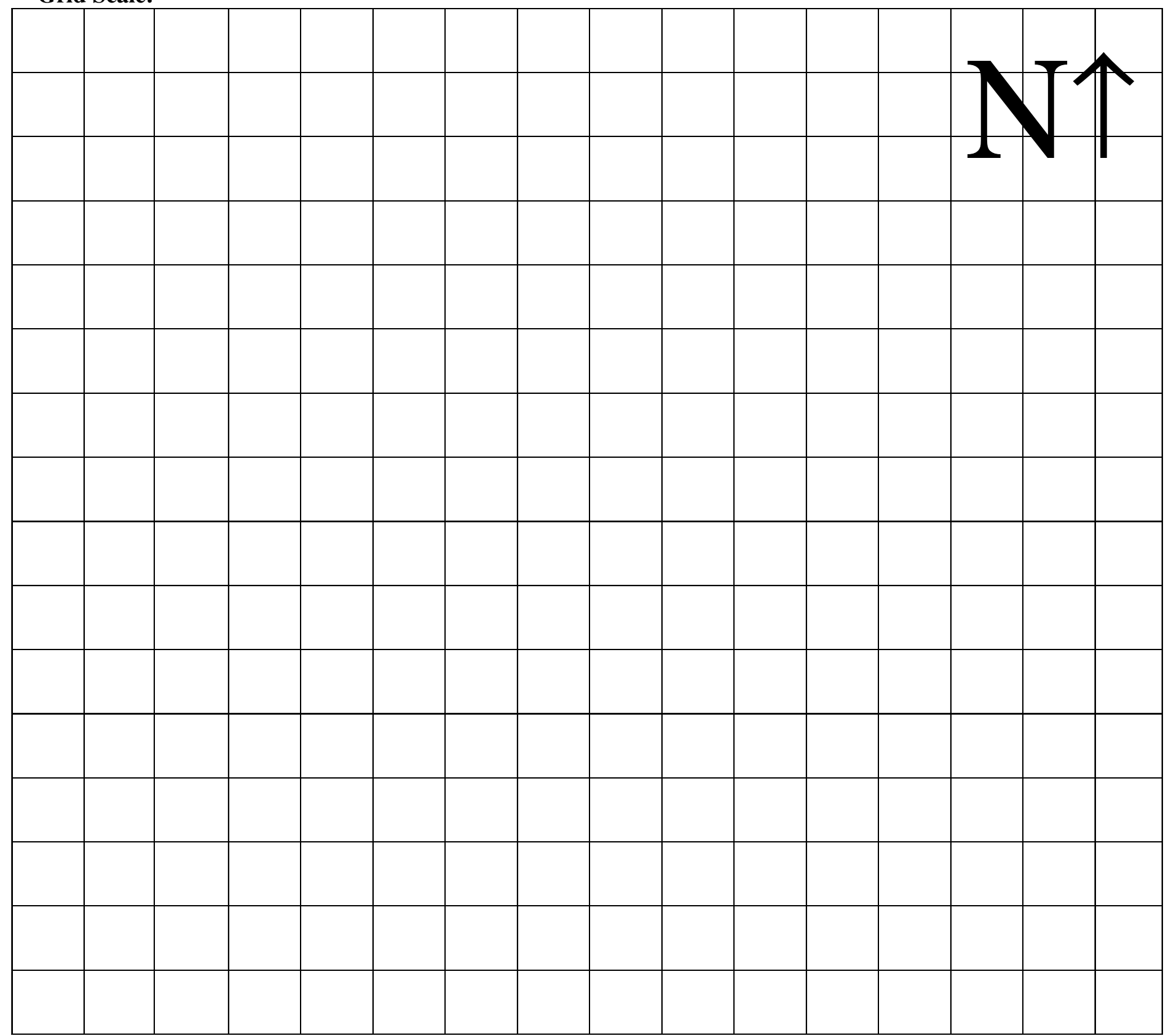

* Draw a rough sketch of the site labeling major features such as streams, talus slopes, habitat cover types, etc. Be sure to indicate where animals were detected and label the following locations on the map: $\mathbf{G}=$ GPS reading, and $\mathbf{P} \rightarrow=$ photo locations and directions of photos.

Other Notes: 
Date:

\section{Mollusk Species Information Continued}

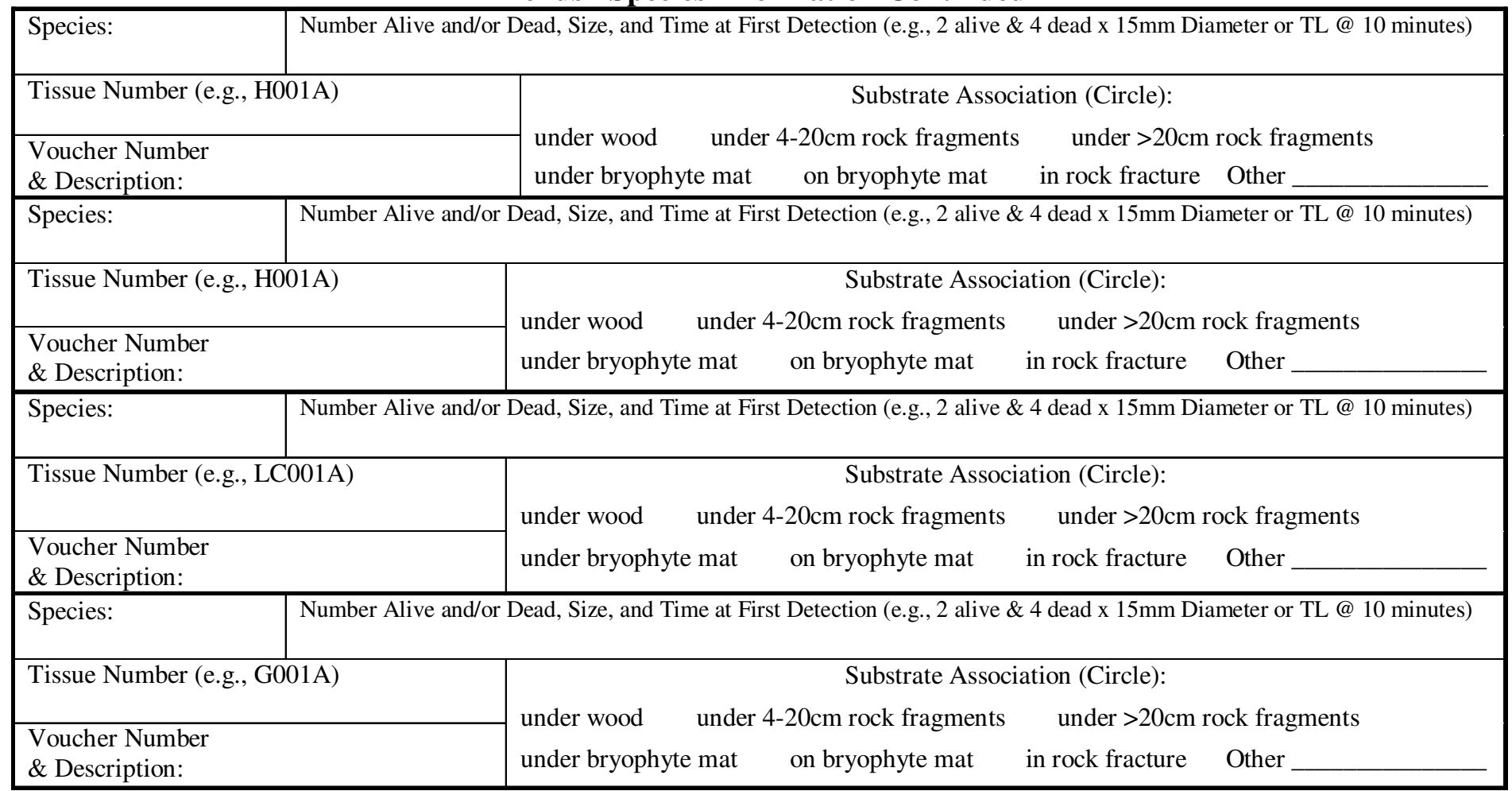

\section{Other Species Information}

\begin{tabular}{|l|l|l|l|}
\hline $\begin{array}{l}\text { Other Species: } \\
\text { (millipedes etc.) }\end{array}$ & $\begin{array}{l}\text { Time at First } \\
\text { Detection: }\end{array}$ & $\begin{array}{l}\text { Voucher } \\
\text { Number: }\end{array}$ & Voucher Description / Comments: \\
\hline $\begin{array}{l}\text { Other Species: } \\
\text { (millipedes etc.) }\end{array}$ & $\begin{array}{l}\text { Time at First } \\
\text { Detection: }\end{array}$ & $\begin{array}{l}\text { Voucher } \\
\text { Number: }\end{array}$ & Voucher Description / Comments: \\
\hline $\begin{array}{l}\text { Other Species: } \\
\text { (millipedes etc.) }\end{array}$ & $\begin{array}{l}\text { Time at First } \\
\text { Detection: }\end{array}$ & $\begin{array}{l}\text { Voucher } \\
\text { Number: }\end{array}$ & Voucher Description / Comments: \\
\hline $\begin{array}{l}\text { Other Species: } \\
\text { (millipedes etc.) }\end{array}$ & $\begin{array}{l}\text { Time at First } \\
\text { Detection: }\end{array}$ & $\begin{array}{l}\text { Voucher } \\
\text { Number: }\end{array}$ & Voucher Description / Comments: \\
\hline $\begin{array}{l}\text { Other Species: } \\
\text { (millipedes etc.) }\end{array}$ & $\begin{array}{l}\text { Time at First } \\
\text { Detection: }\end{array}$ & $\begin{array}{l}\text { Voucher } \\
\text { Number: }\end{array}$ & Voucher Description / Comments: \\
\hline $\begin{array}{l}\text { Other Species: } \\
\text { (millipedes etc.) }\end{array}$ & $\begin{array}{l}\text { Time at First } \\
\text { Detection: }\end{array}$ & $\begin{array}{l}\text { Voucher } \\
\text { Number: }\end{array}$ & Voucher Description / Comments: \\
\hline
\end{tabular}

\section{Other Notes:}


Ecoregion: One of the 14 ecoregion sections in Montana or 6 in the Idaho Panhandle.

Sample Block: Identify three digit number of the sampling block (range 001-999).

Site No: Identify three digit number of the site being surveyed within each sampling block (range 001-999).

Locality: Describe the specific geographic location of the site so that the type of site is described and the straight-line air distance from one or more permanent features on a 7.5-minute (1:24,000 scale) topographic map records the position of the site (e.g., Large talus slope 1.5 miles north of Engle Peak, N side of FS Road 225).

State: Use the two-letter abbreviation.

County: Use the full county name.

Map Name: List the name of the USGS 7.5-minute (1:24,000 scale) topographic quadrangle map.

T: Record the Township number and whether it is north or south.

R: Record the Range number and whether it is east or west.

S: Record the Section number

Section Description: Describe location of the site at the 1/4 of $1 / 4$ section level (e.g., SENE indicates SE corner of NE corner). Owner: Use abbreviation of the government agency responsible for managing the land you surveyed. (e.g. USFS, BLM). If private land was surveyed list the owner's full name to indicate that you did not trespass.

Map Elevation: The elevation of the site as indicated by the topographic map in feet (avoid using elevations from a GPS)

Datum: The map datum used (typically NAD 27 if off topographic map or WGS84 if off GPS unit on standard setting).

UTM Zone: Universal Transverse Mercator zone recorded on the topographic map.

UTM East: Universal Transverse Mercator easting coordinate in meters as recorded on the topographic map or GPS receiver. Be sure to note any major differences between UTM coordinates on the map and those on the GPS receiver.

UTM North: Universal Transverse Mercator northing coordinate in meters as recorded on the topographic map or GPS receiver. Be sure to note any major differences between UTM coordinates on the map and those on the GPS receiver.

\section{Survey Information}

Date: Use MM-DD-YY format (e.g. 05/12/00 for May 12 of 2000).

Observers: List names or initials of individuals involved with survey of this site and circle the name of the recorder.

Begin Time: List the time the survey began in 24-hour format.

End Time: List the time the survey ended in 24-hour format.

Total Person Minutes of Search: Record the total person minutes the site was searched (e.g. if one person surveys for 15 minutes and another surveys for 30 minutes, but takes 5 minutes to measure a specimen the total person minutes is 40 minutes). Area $\left(\mathbf{M}^{2}\right)$ Searched: Area in square meters that was surveyed.

Percent of Site Searched: Circle the appropriate category.

Percent Slope: Percent slope of site. Enter range if variable.

Aspect: Circle primary aspect of the site.

Habitat Type: Circle the appropriate habitat type.

Primary Canopy Species: List the major plant species in the canopy (e.g., red cedar, western hemlock, grand fir, ninebark)

Overall Percent Canopy Cover: Circle the appropriate category for total canopy cover.

Canopy Species Average DBH: Circle the appropriate category.

Photo Frame Number(s) / Descriptions: The number of the photo as viewed on the camera's view screen and a description of the contents of the photograph (e.g., \#13 = 1 x Oreohelix strigosa and \#14-18 = $5 \mathrm{x}$ habitat). Take photos of all portions of the site and anything else that may be of interest (e.g., millipedes, potential site threats).

Weather: Circle weather condition during survey.

Air Temp: Record air temperature in ${ }^{\circ} \mathrm{C}$ at chest height in the shade. ${ }^{\circ} \mathrm{C}=\left({ }^{\circ} \mathrm{F}-32\right) / 1.8$

Soil Temp: Record soil temperature in ${ }^{\circ} \mathrm{C}$ at $10 \mathrm{~cm}$ depth. ${ }^{\circ} \mathrm{C}=\left({ }^{\circ} \mathrm{F}-32\right) / 1.8$

Soil Moisture: Circle the appropriate category.

Rock Type: Circle the appropriate category; note specific type if known.

Habitat Threats: Note impacts from grazing, logging, mining, flooding, road building, weeds, fire, etc.

Species Information

For each species, record the genus name and species, if known. If species cannot be identified in the field, place a brief description of their morphology here. Record the number alive and dead, and size range for individuals encountered, and time at first detection for the first individual encountered (e.g., 2 × $15 \mathrm{~mm}$ diameter (shells) or TL = 80-90mm (slugs): @ 10 minutes). Record the tissue number or range of tissue numbers for tissue samples collected (see tissue collection protocols). Record the preliminary museum voucher specimen number and description for voucher specimens collected (see voucher specimen collection protocols). Circle the substrate the animal was associated with at time of detection. Record the presence of other species detected at the site (e.g., millipedes), the time at first detection, and the voucher number and description of animals collected (see voucher and tissue collection protocols). 


\section{Appendix D. Example Species Photographs}





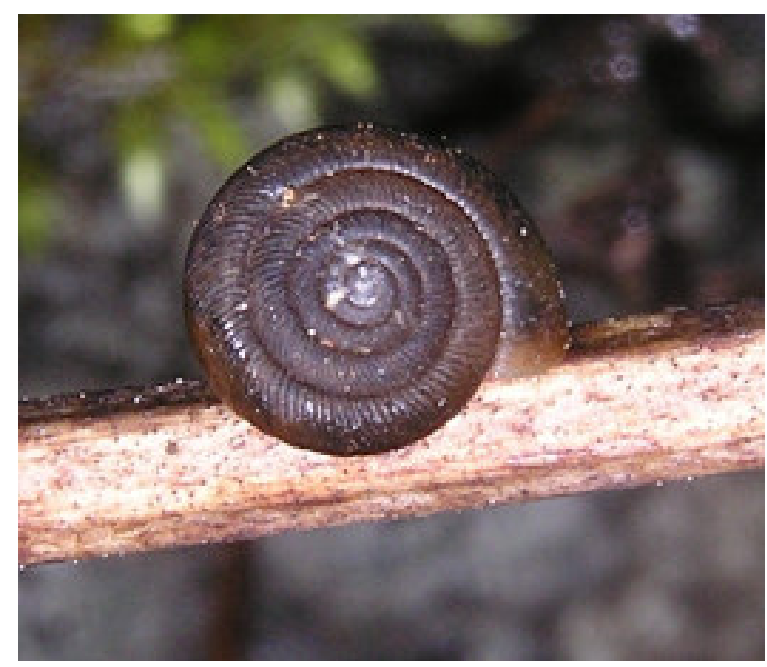

Radiodiscus abietum (Fir Pinwheel)

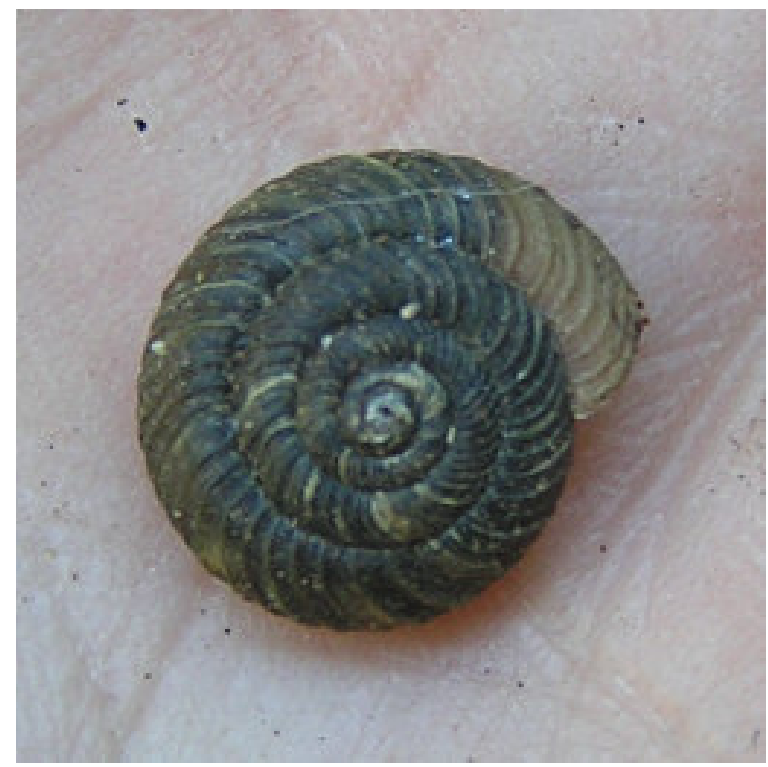

Anguispira nimapuna (Nimapuna Tigersnail)

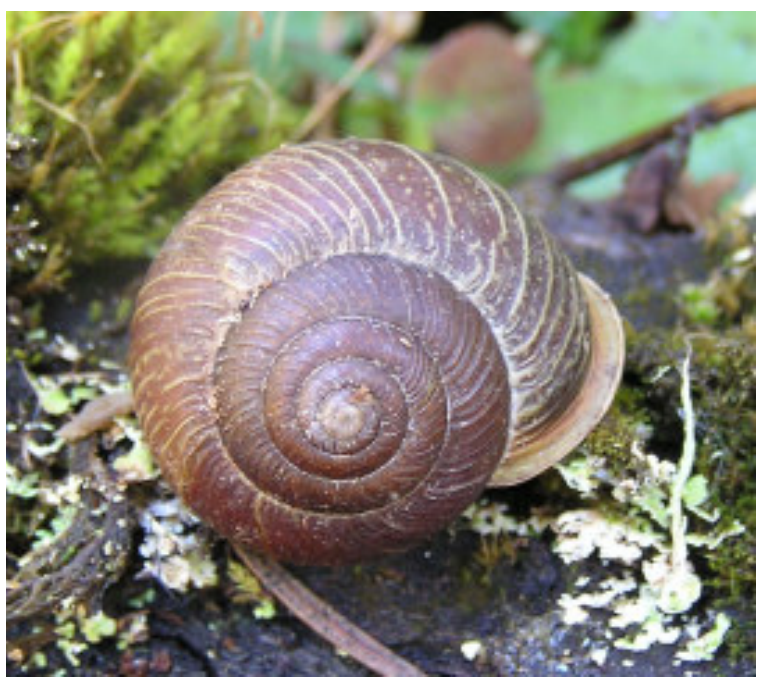

Allogona lombardii (Selway Forestsnail)

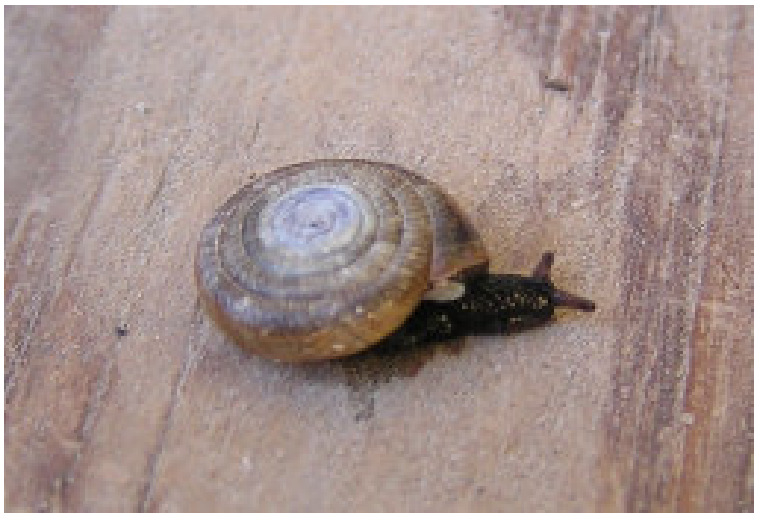

Polygyrella polygyrella (Humped Coin) 


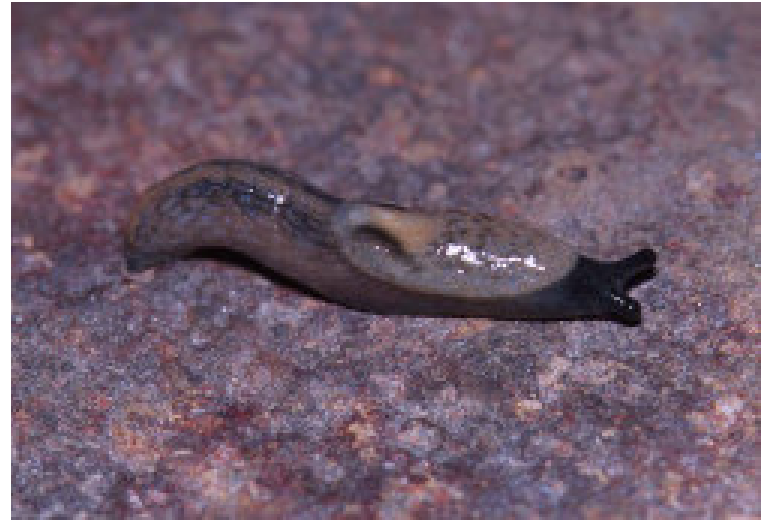

Udosarx lyrata (Lyre Mantleslug)

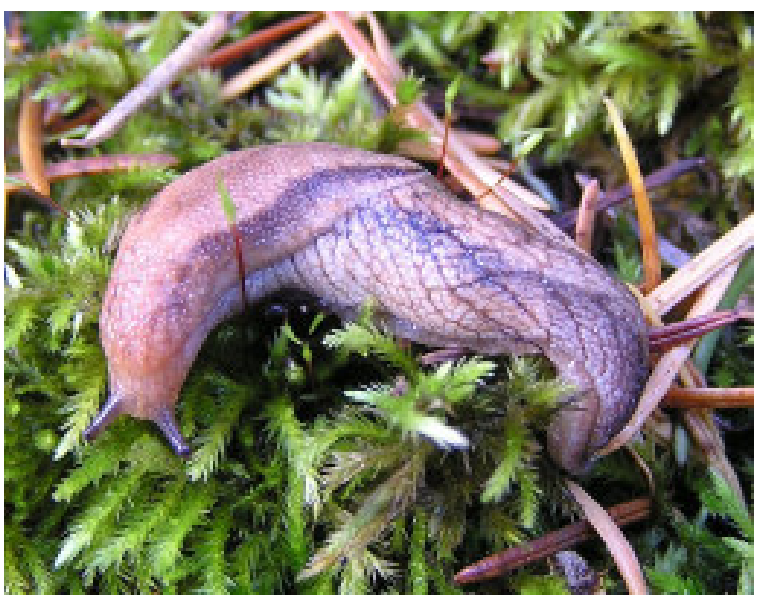

Prophysaon humile (Smoky Taildropper)

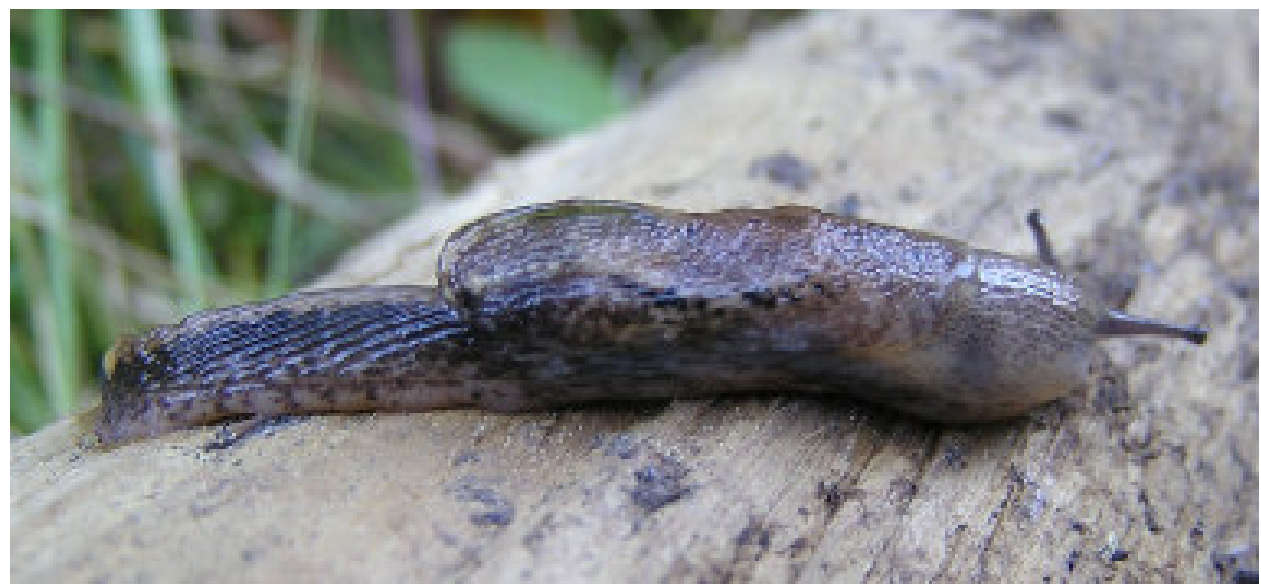

Hemphillia camelus (Pale Jumping-slug)

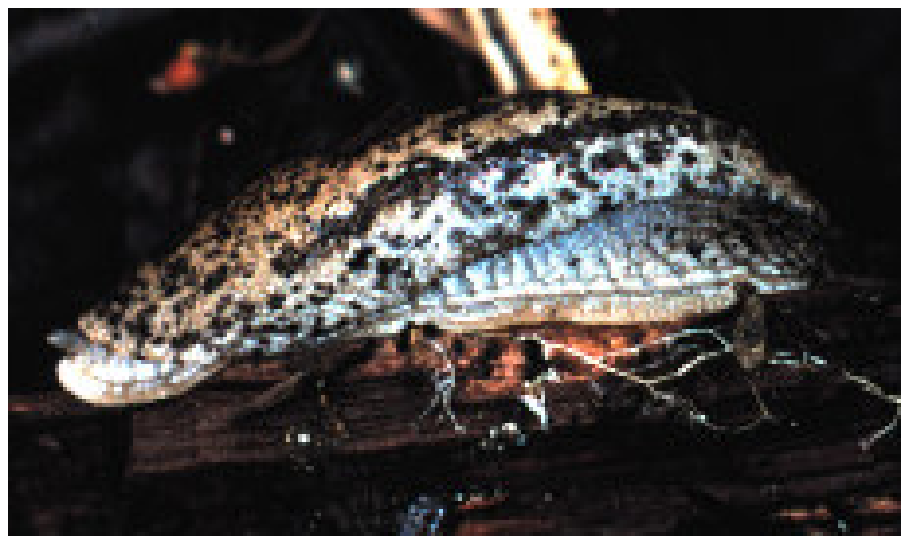

Magnipelta mycophaga (Magnum Mantleslug)

Appendix D - 2 


\section{Appendix E. Distribution Maps for SOC/SOI Land Mollusks on USFS Region 1 LANDS}





\section{Terrestrial Mollusk Data Overview for Montana and Northern Idaho}

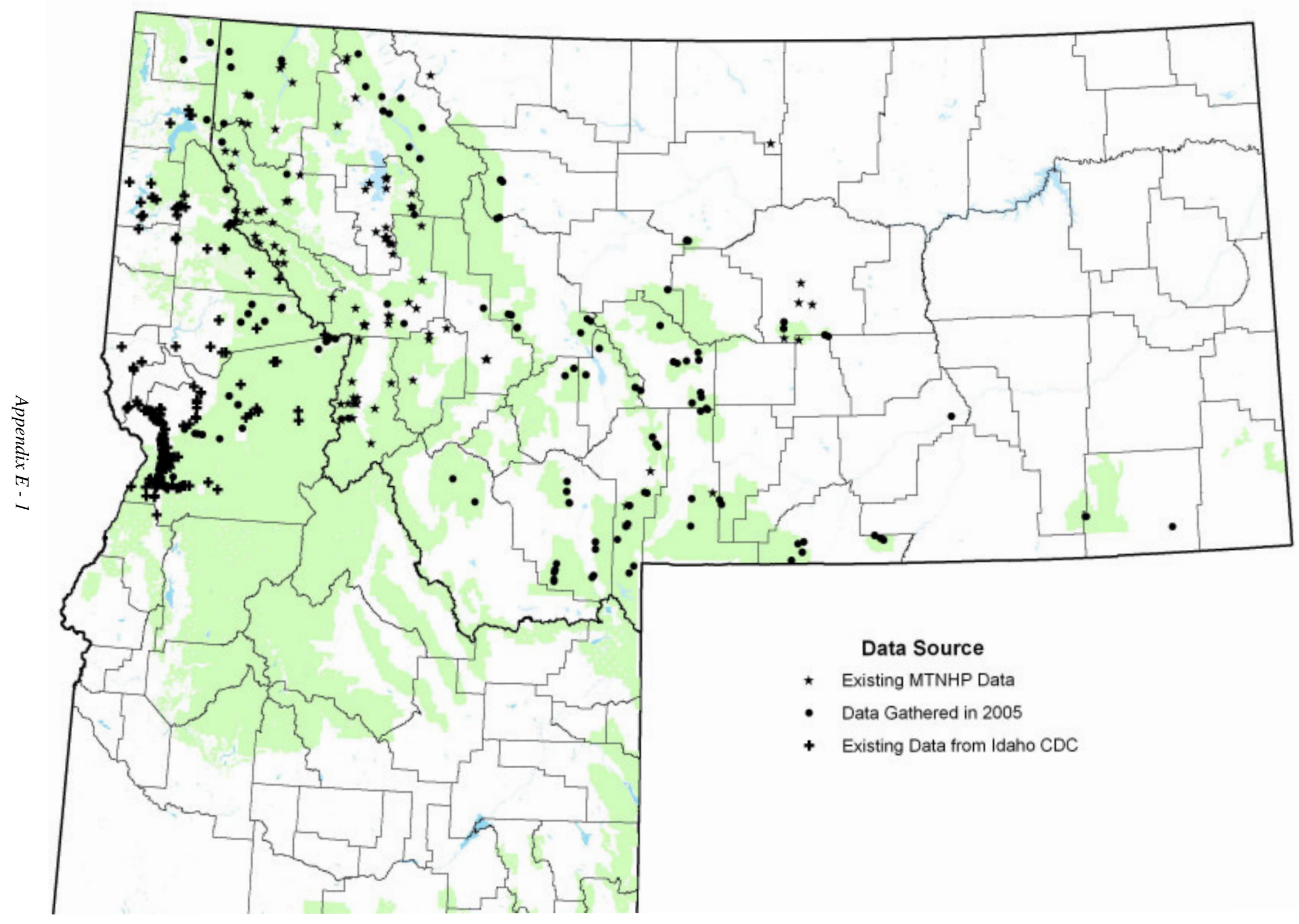




\section{Selway Forestsnail (Allogona lombardii)}

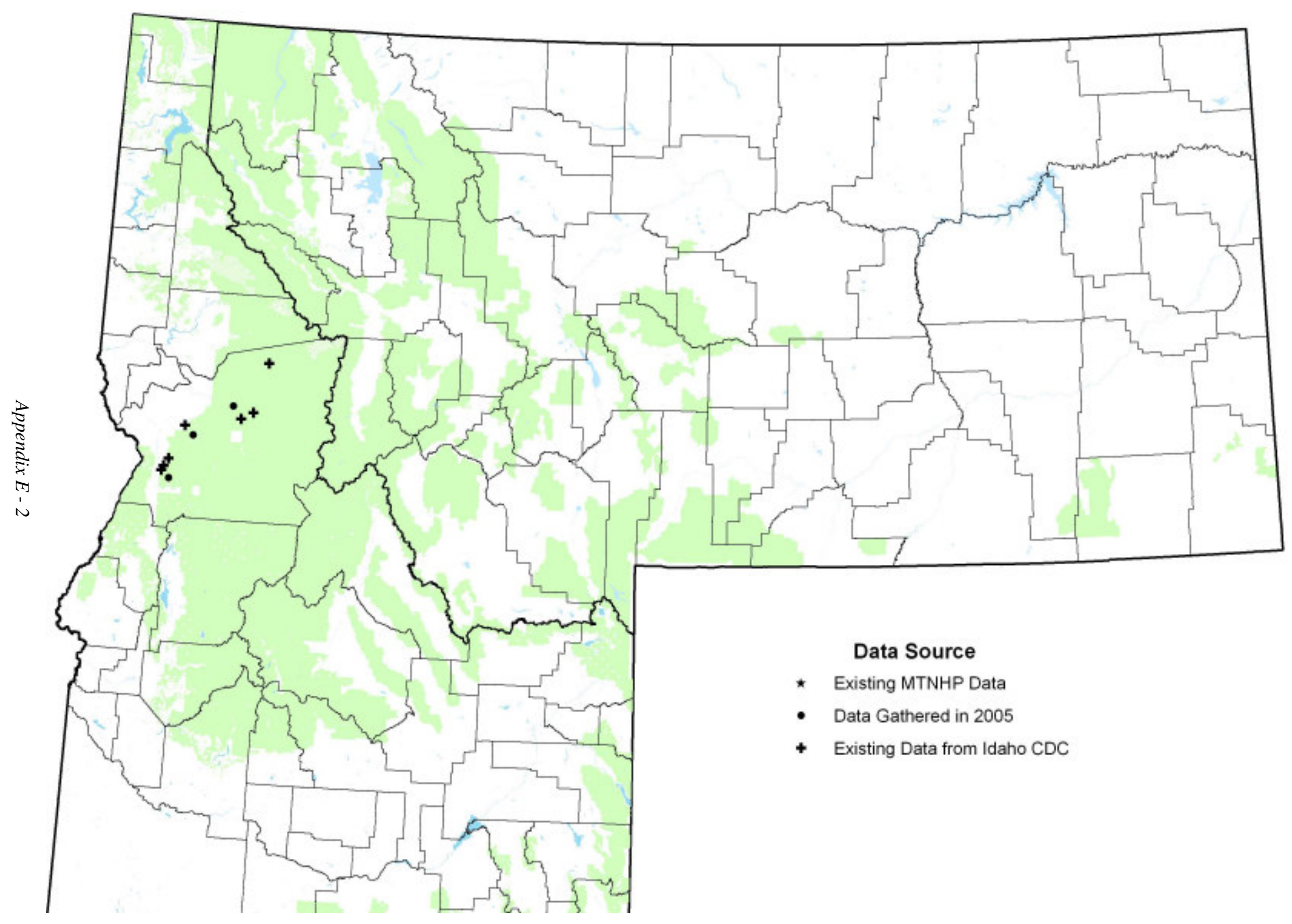




\section{Dry Land Forestsnail (Allogona ptycophora solida)}

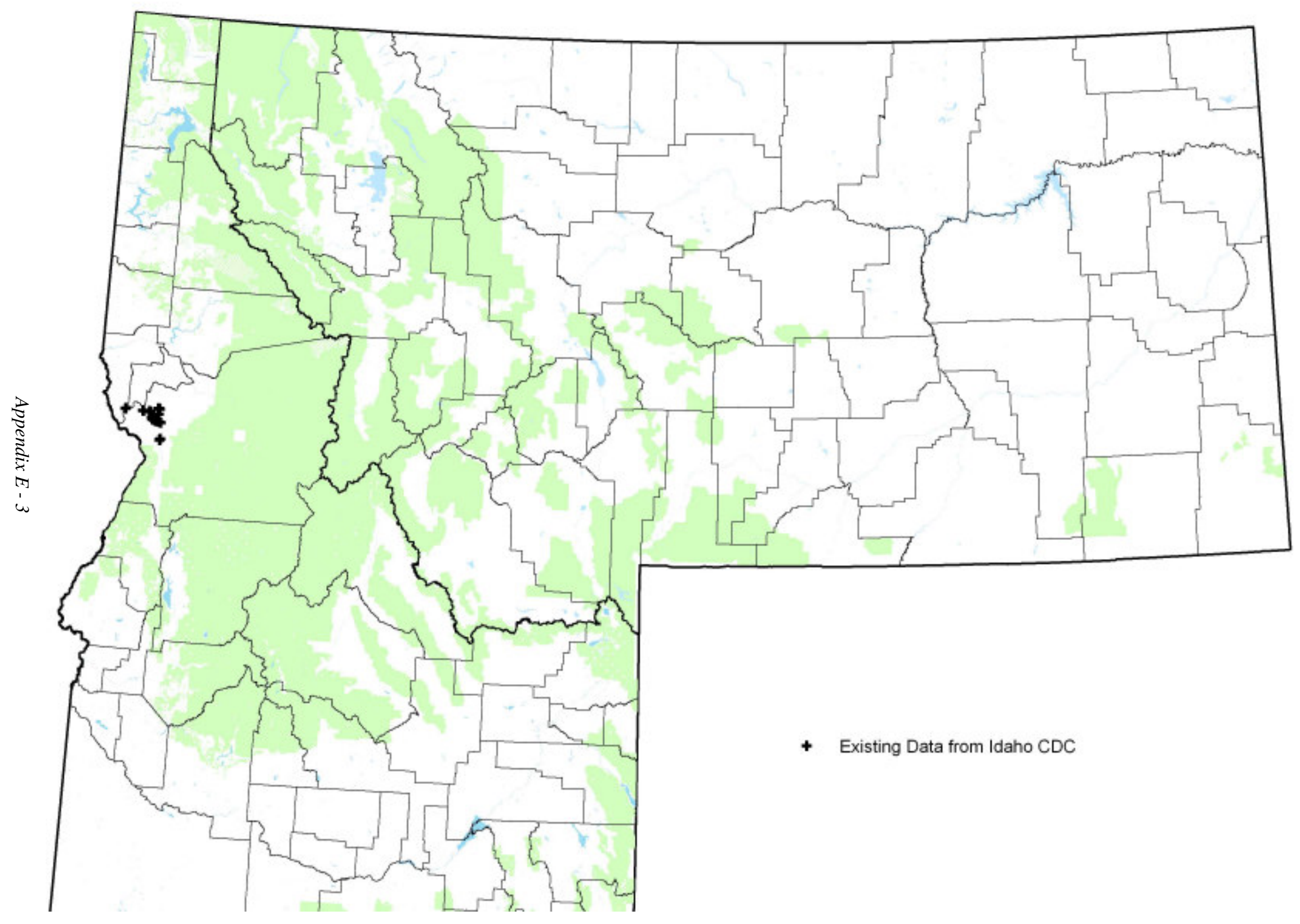




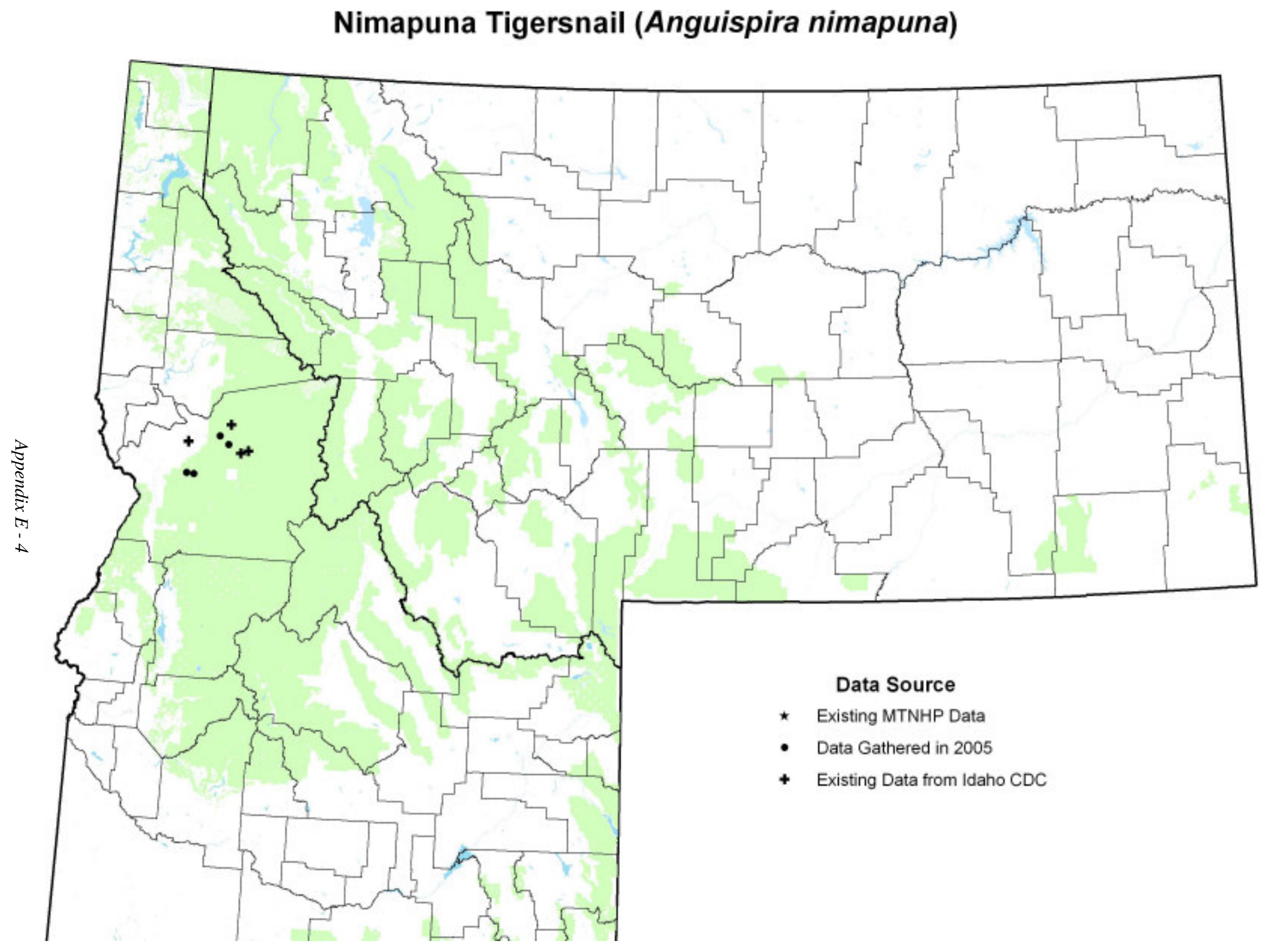




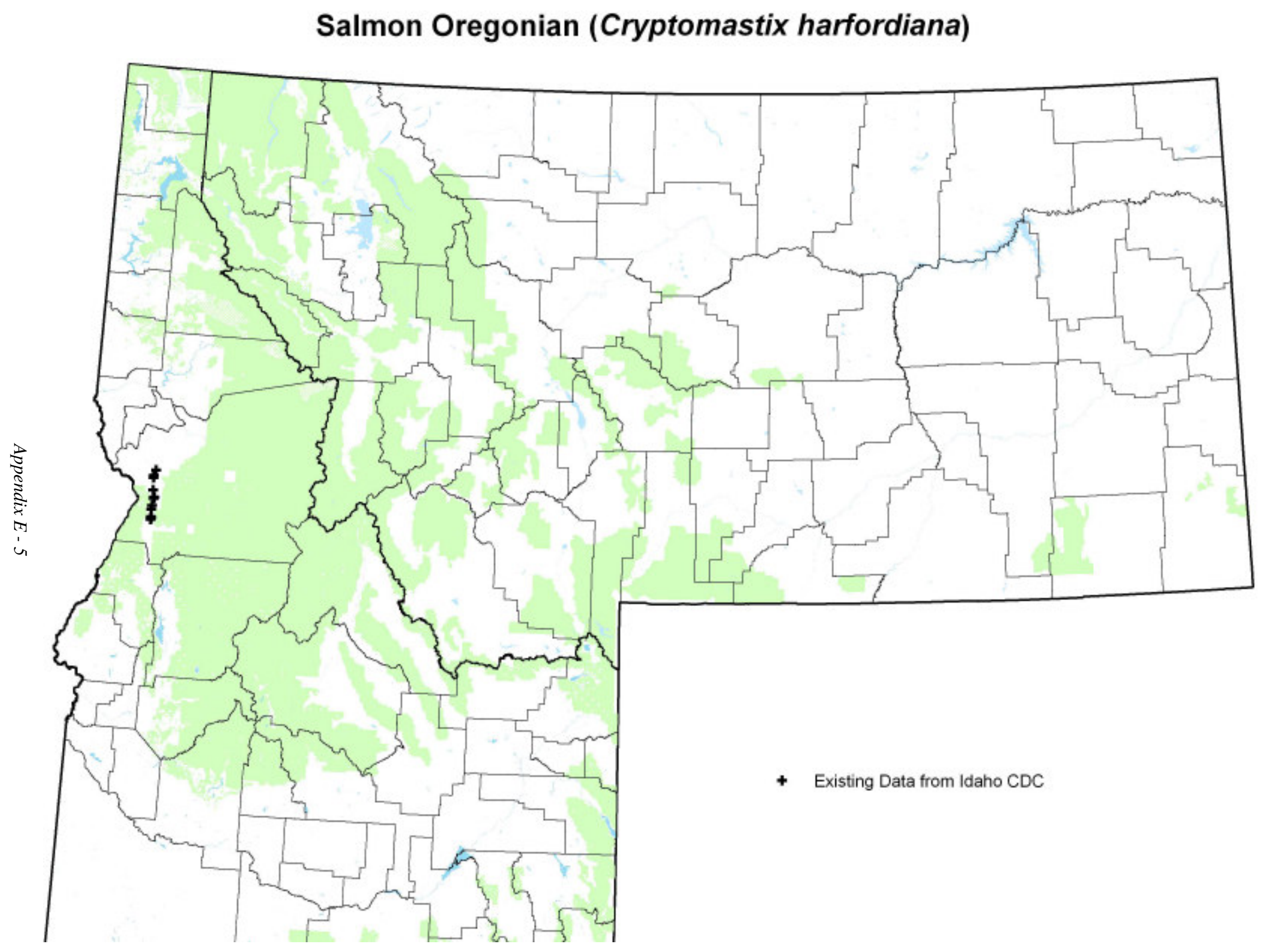


Mission Creek Oregonian (Cryptomastix magnidentata)

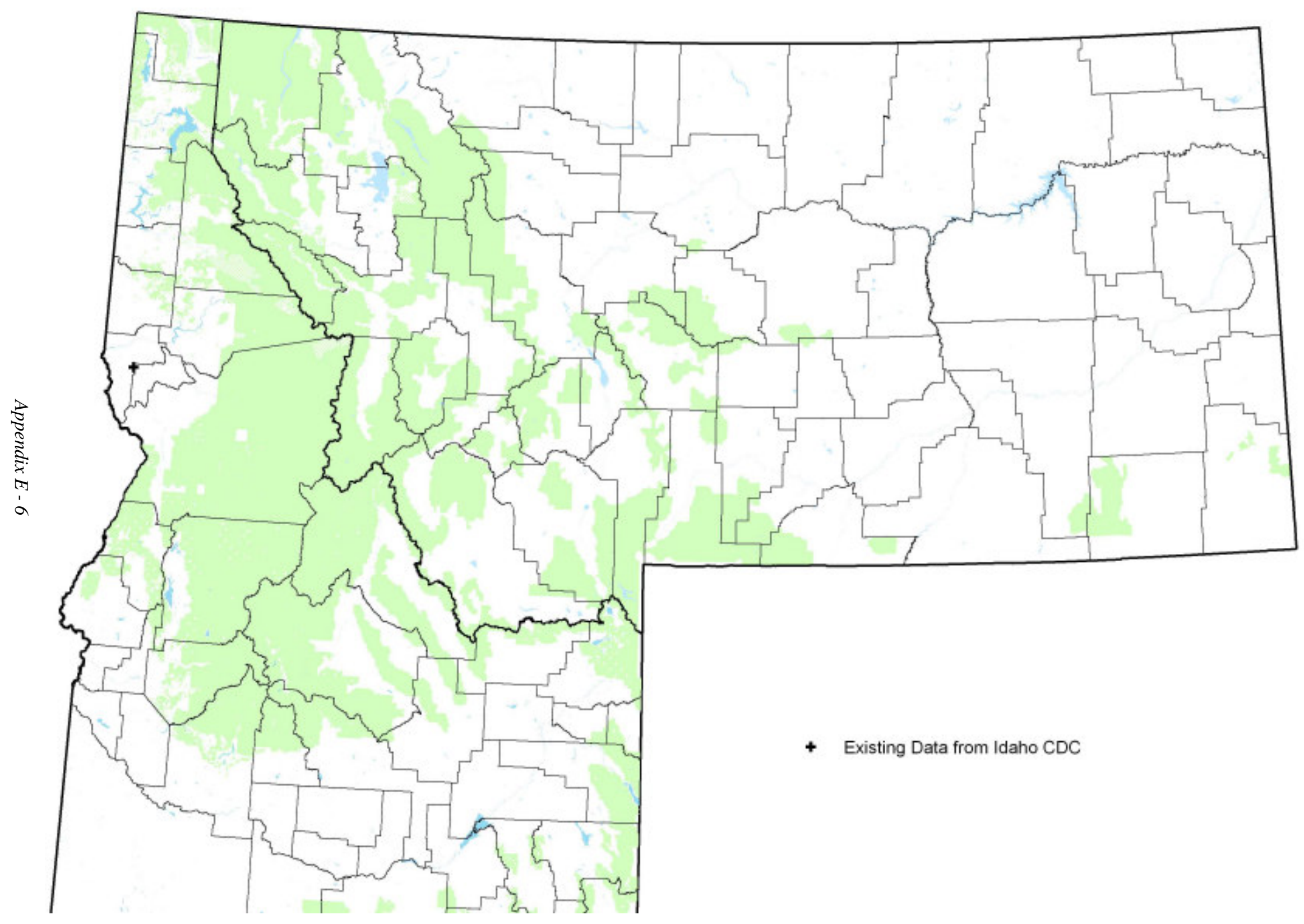




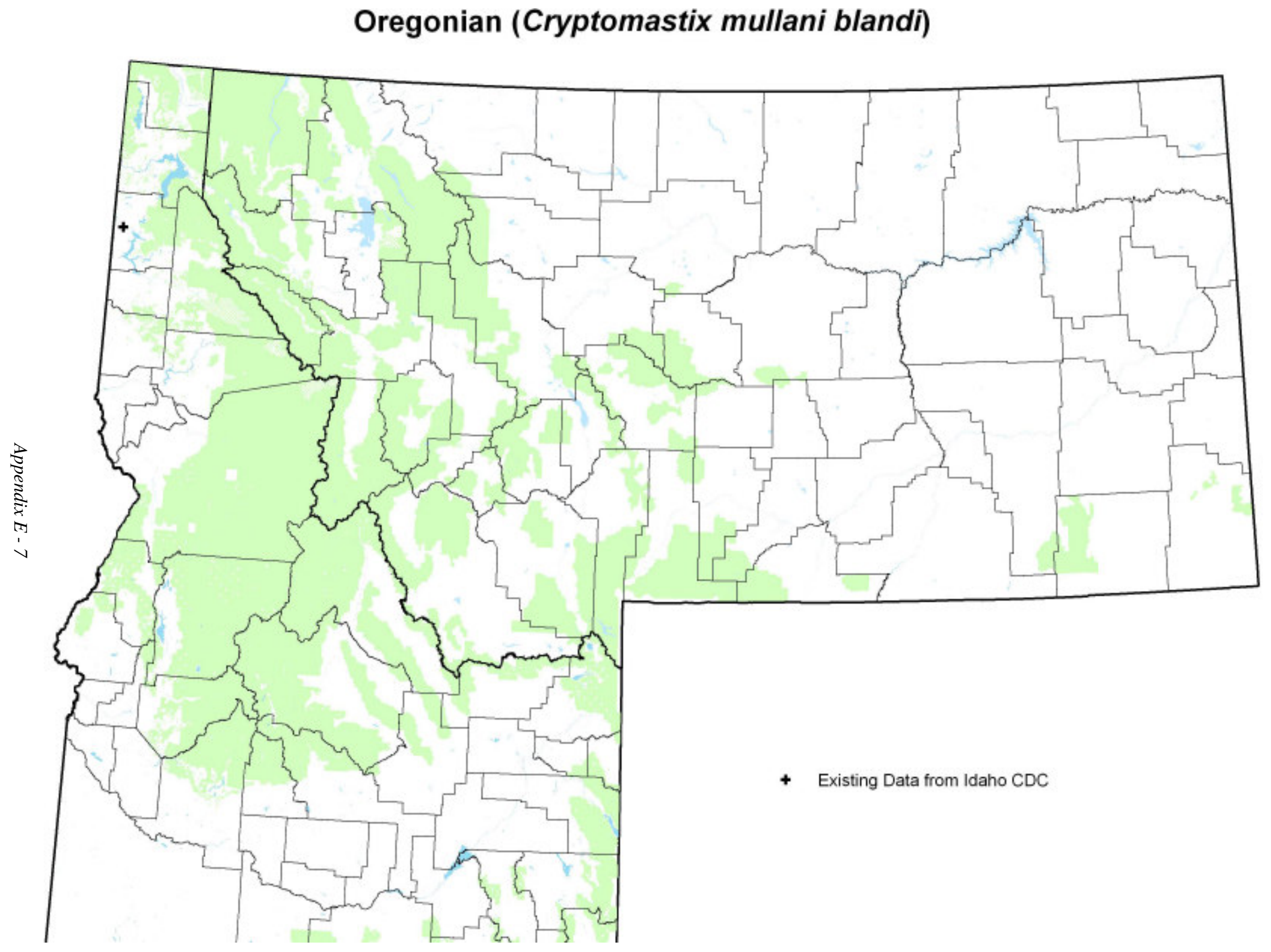


River of No Return Oregonian (Cryptomastix mullani clappi)

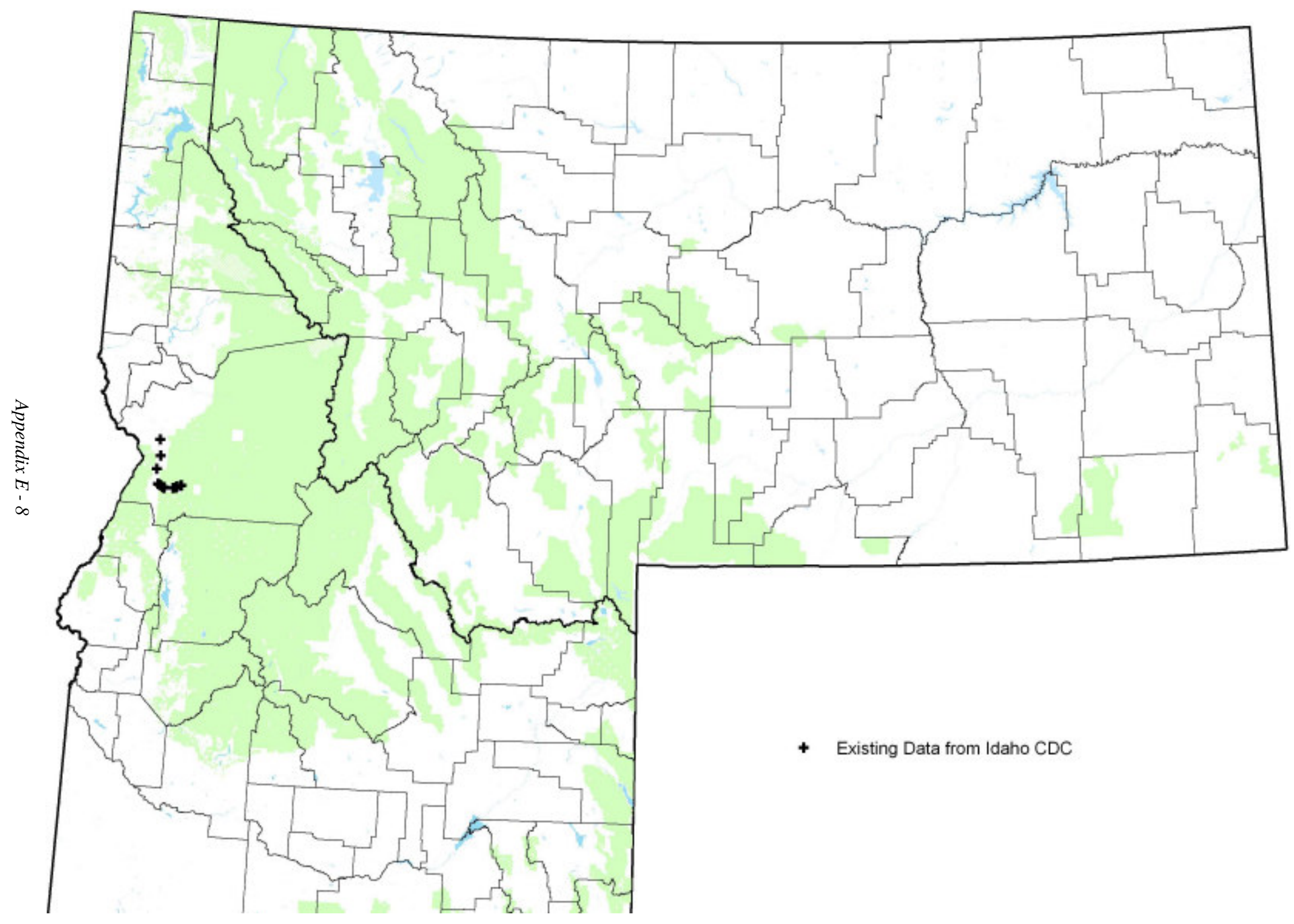




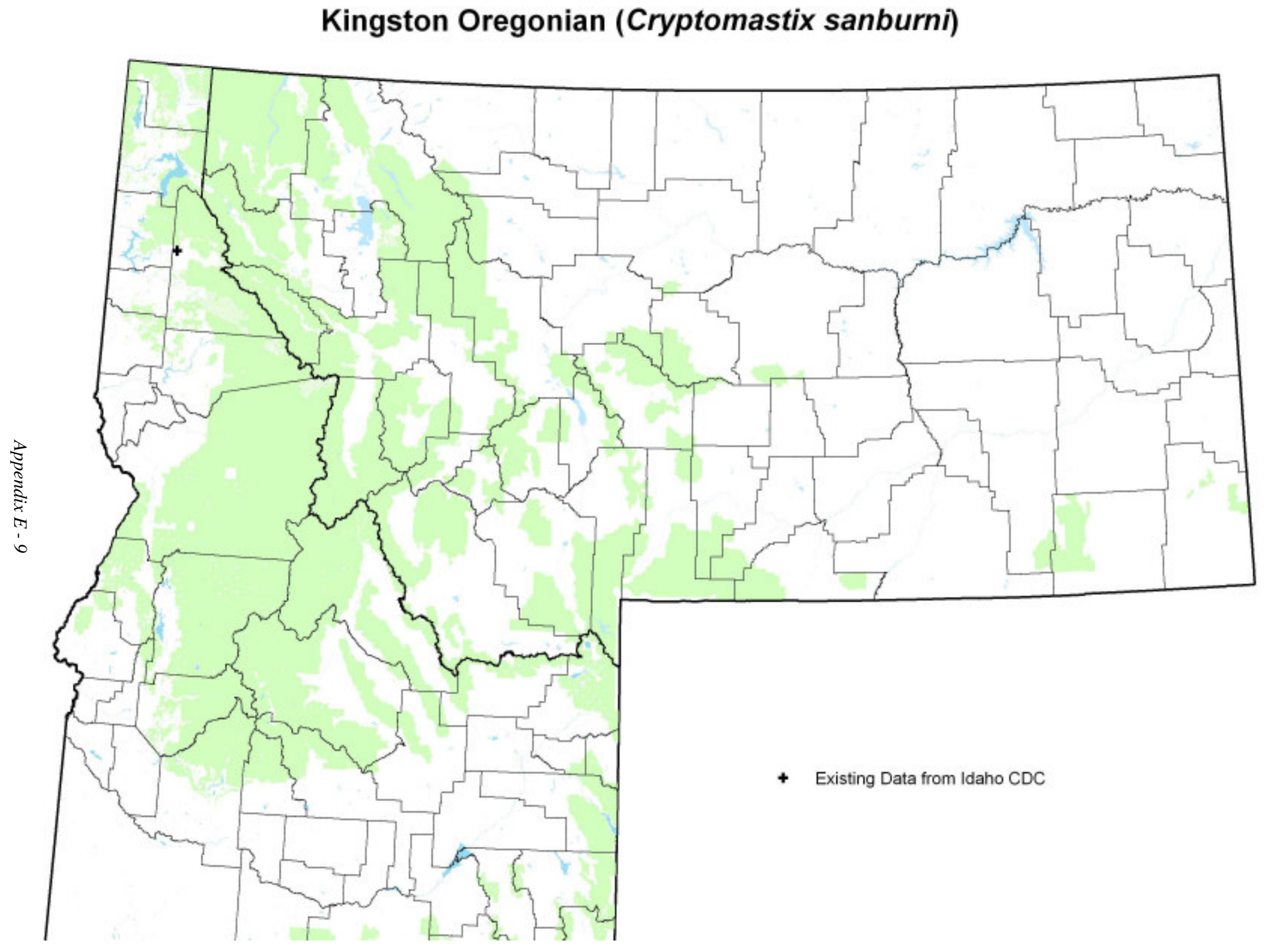




\section{Lake Disc (Discus brunsoni)}

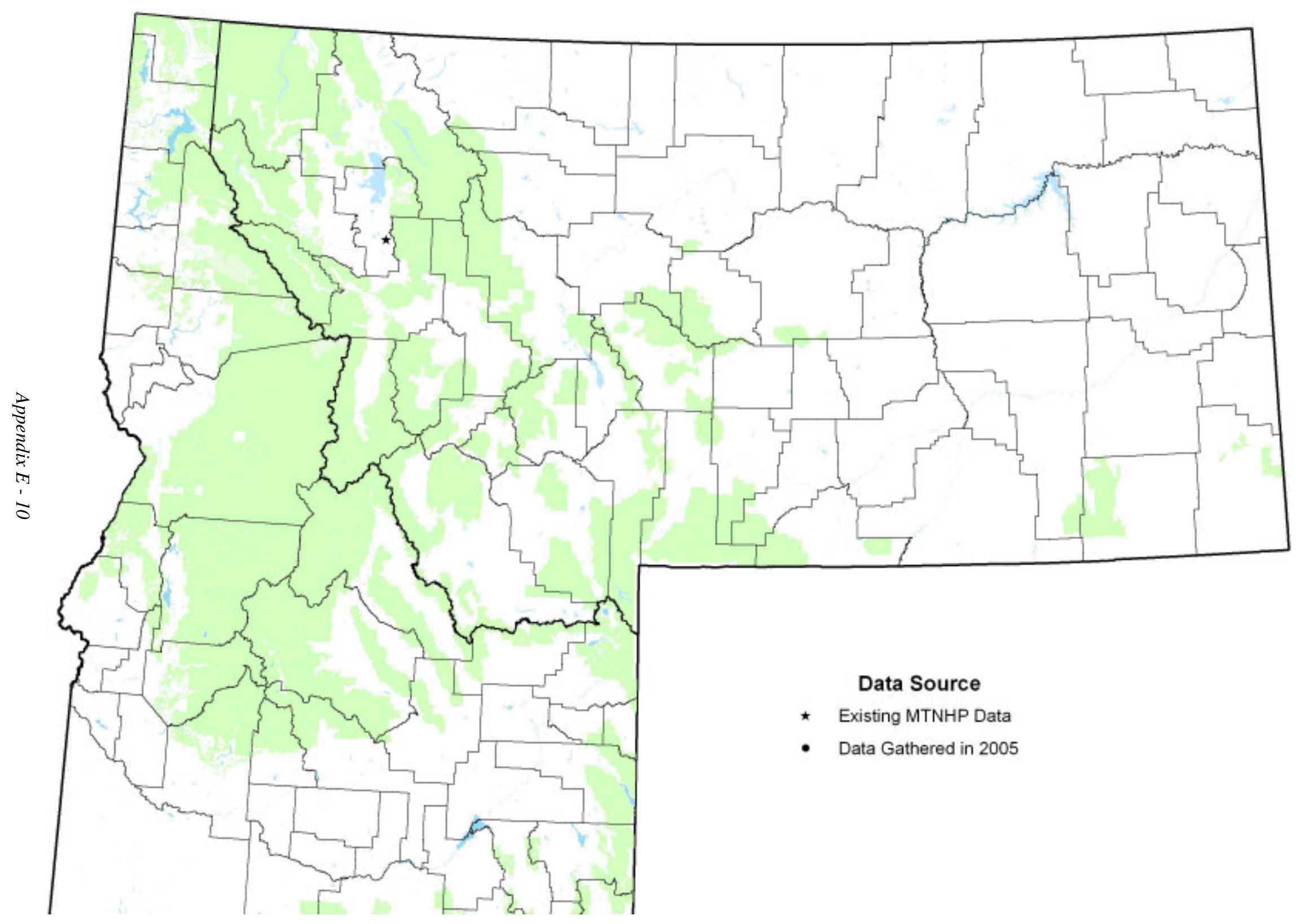




\section{Marbled Disc (Discus marmorensis)}

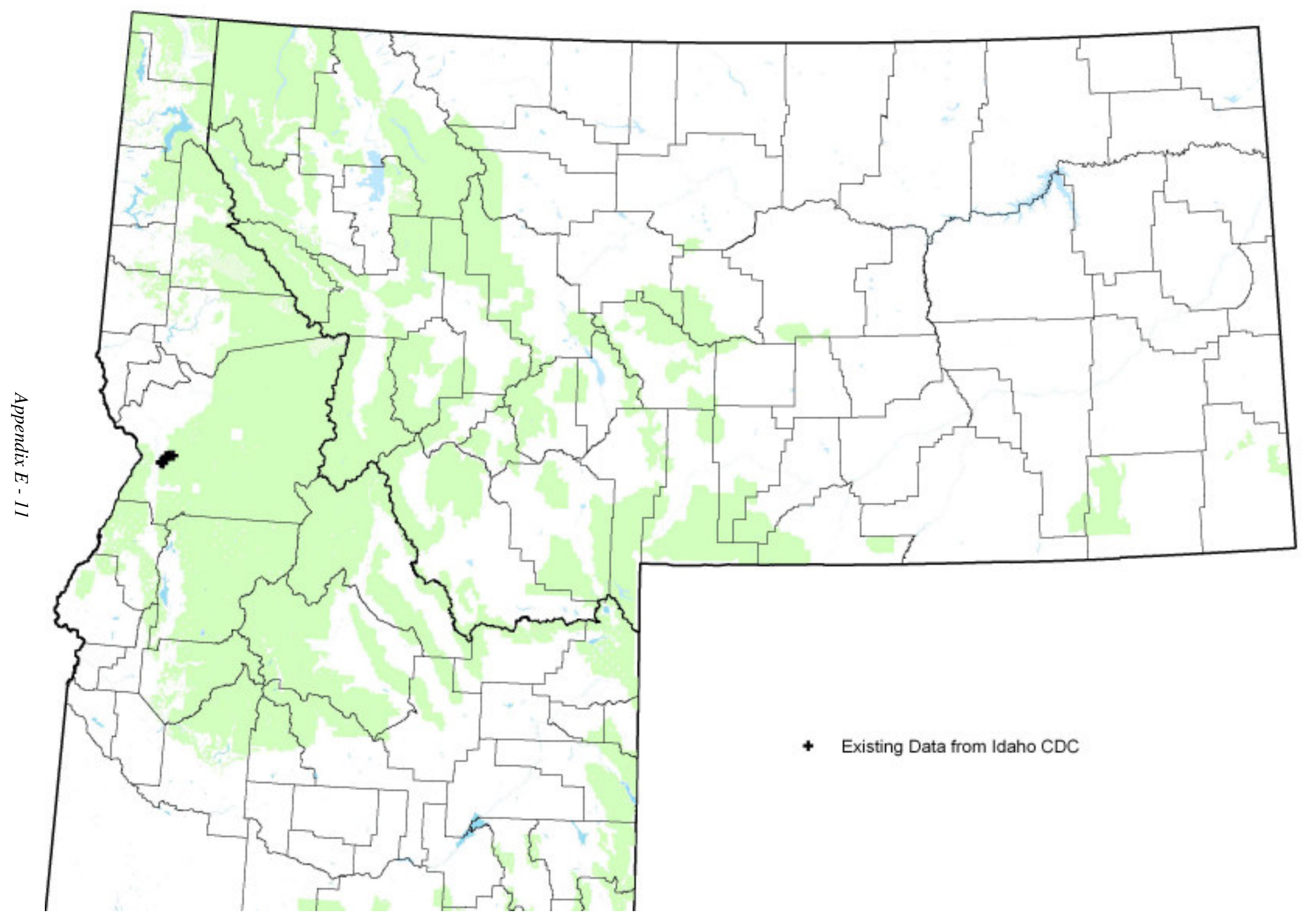




\section{Striate Disc (Discus shimekii)}

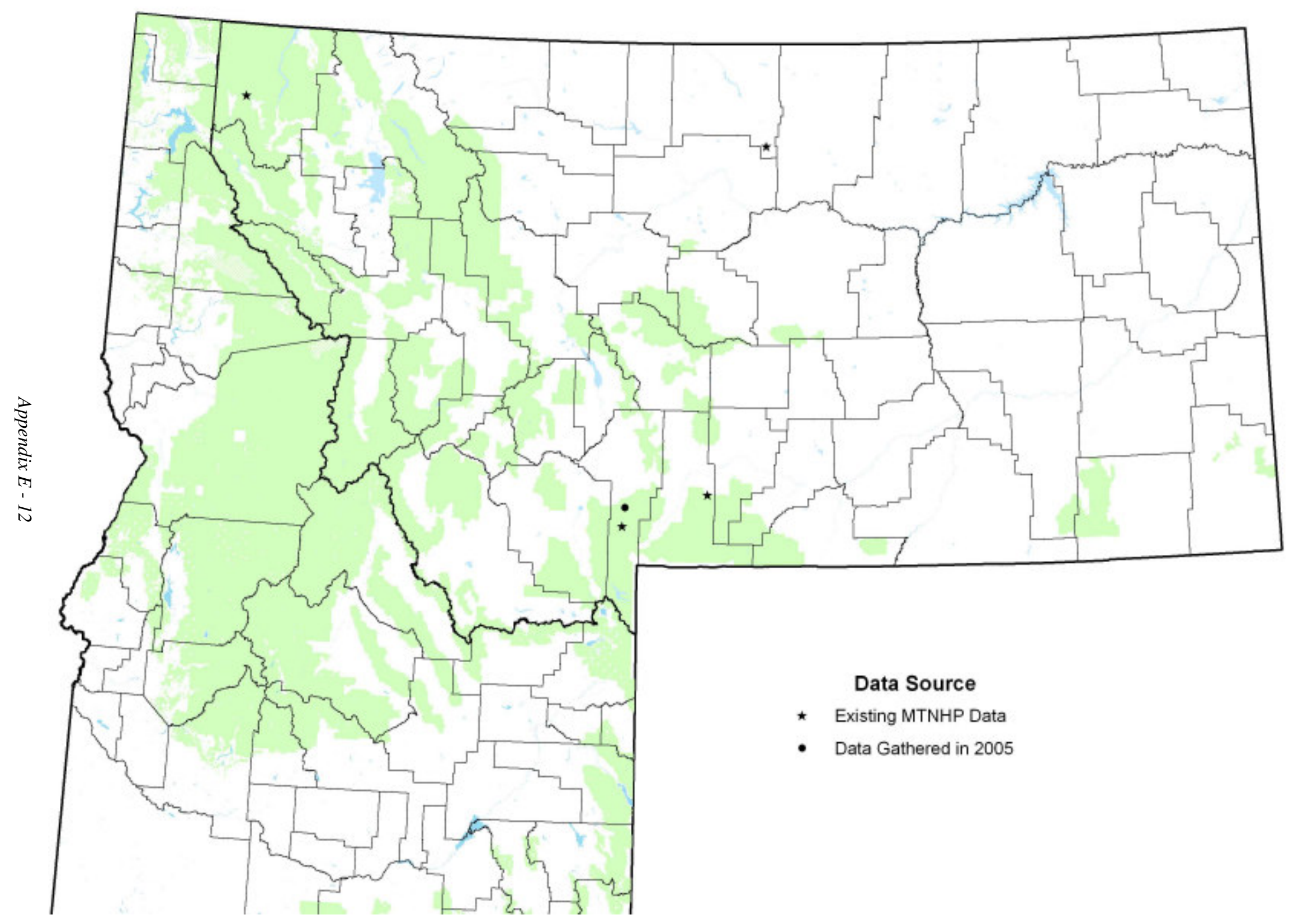


Robust Lancetooth (Haplotrema vancouverense)

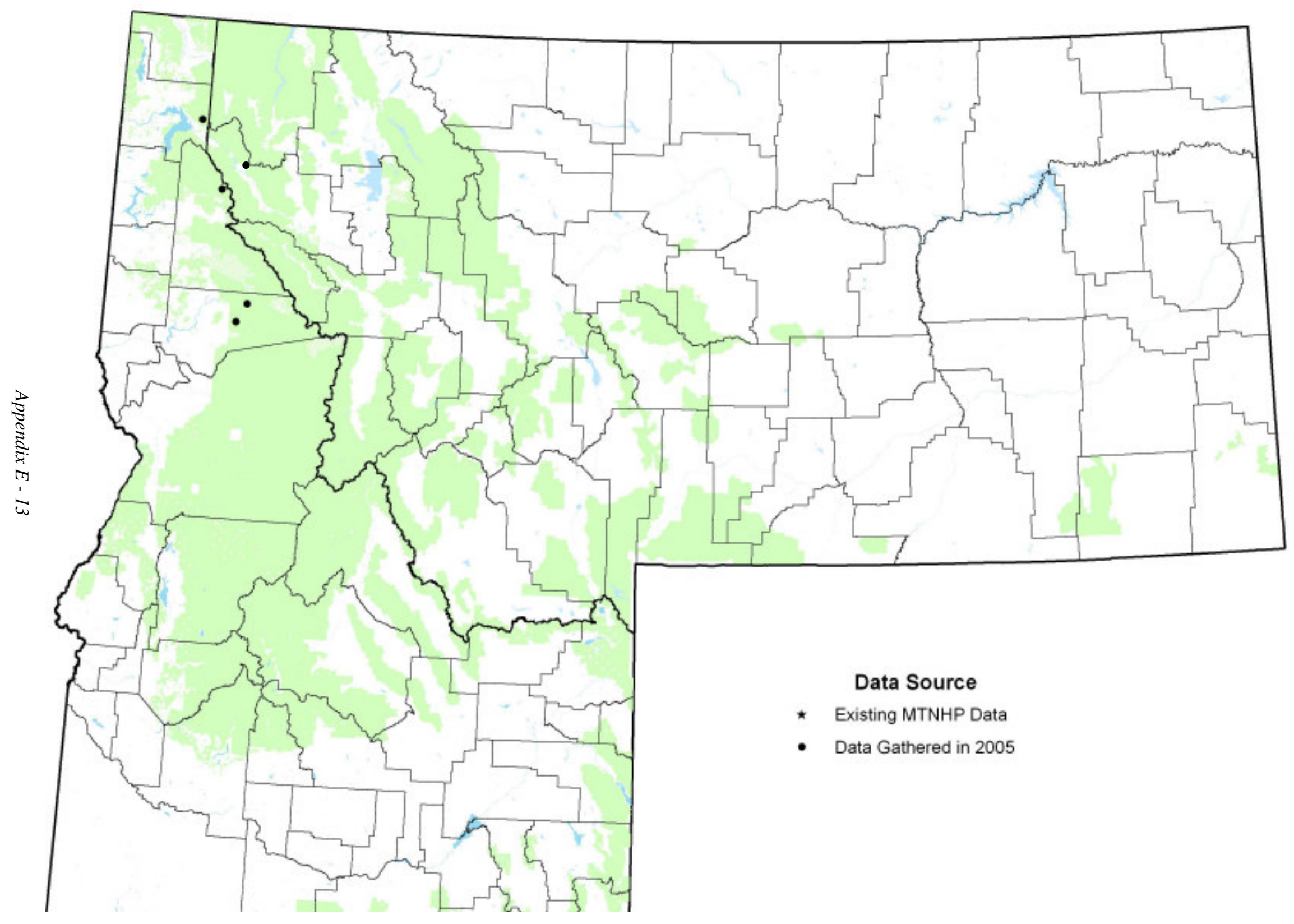


Salmon Coil (Helicodiscus salmonaceus)

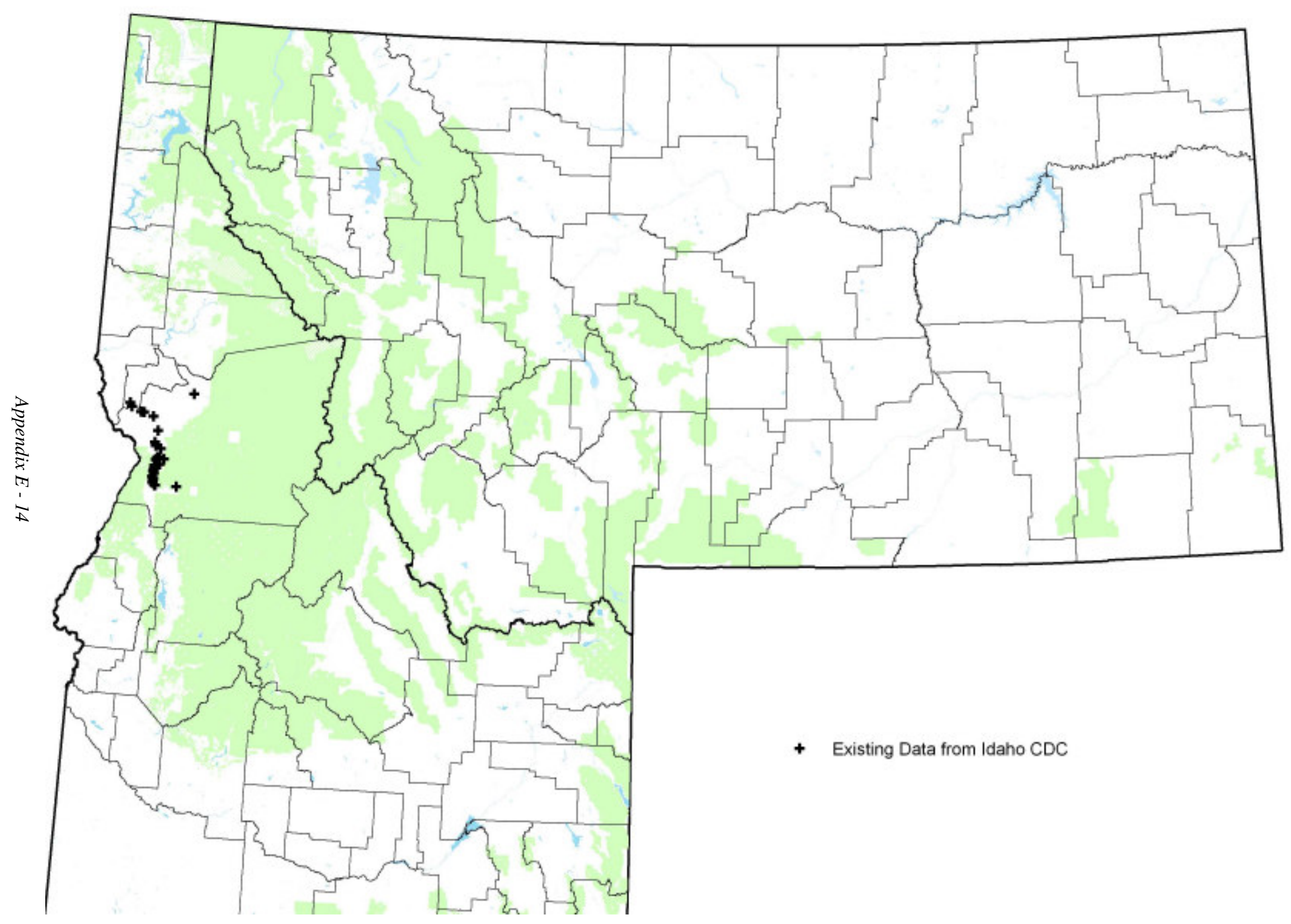




\section{Pale Jumping-slug (Hemphillia camelus)}

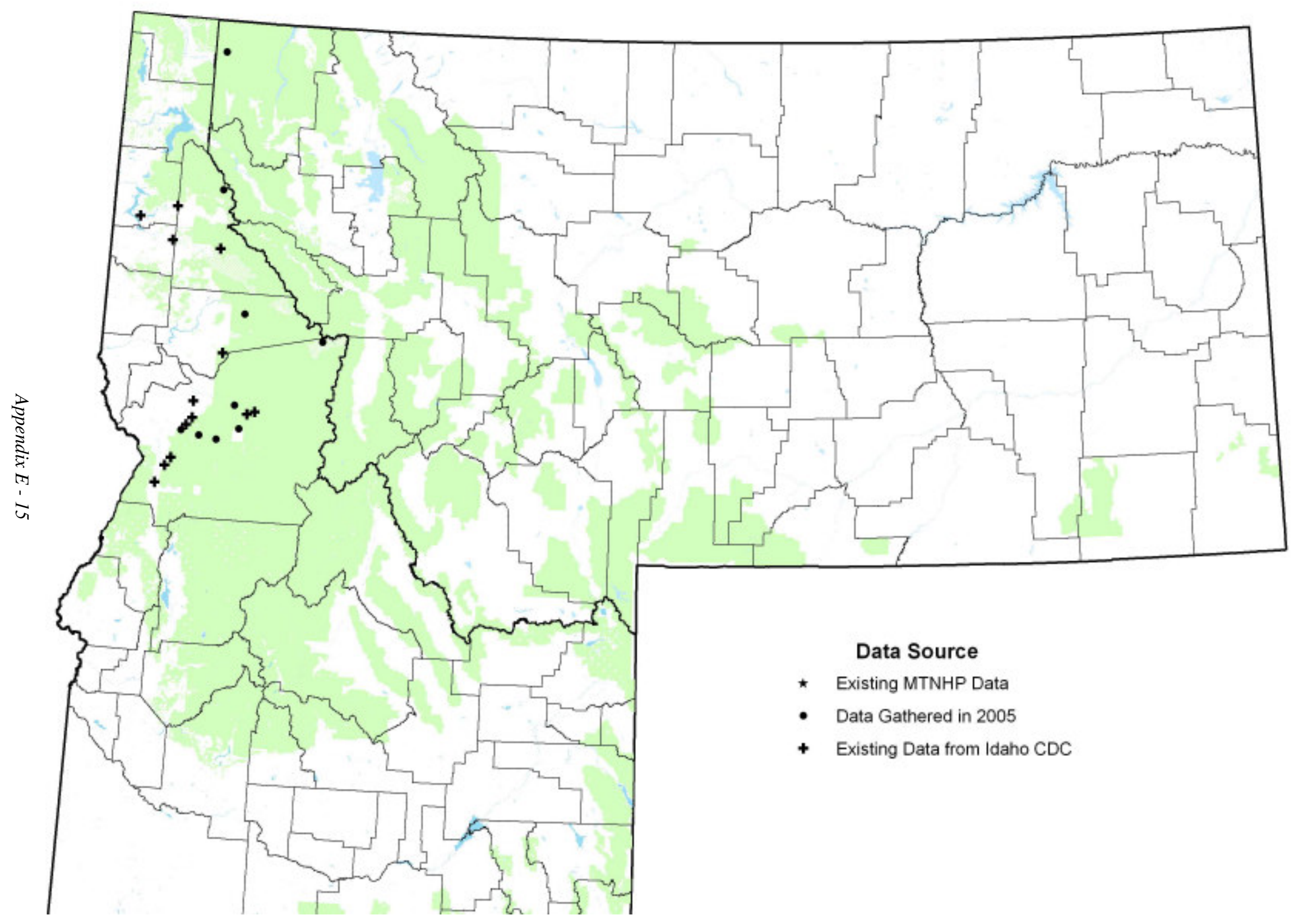




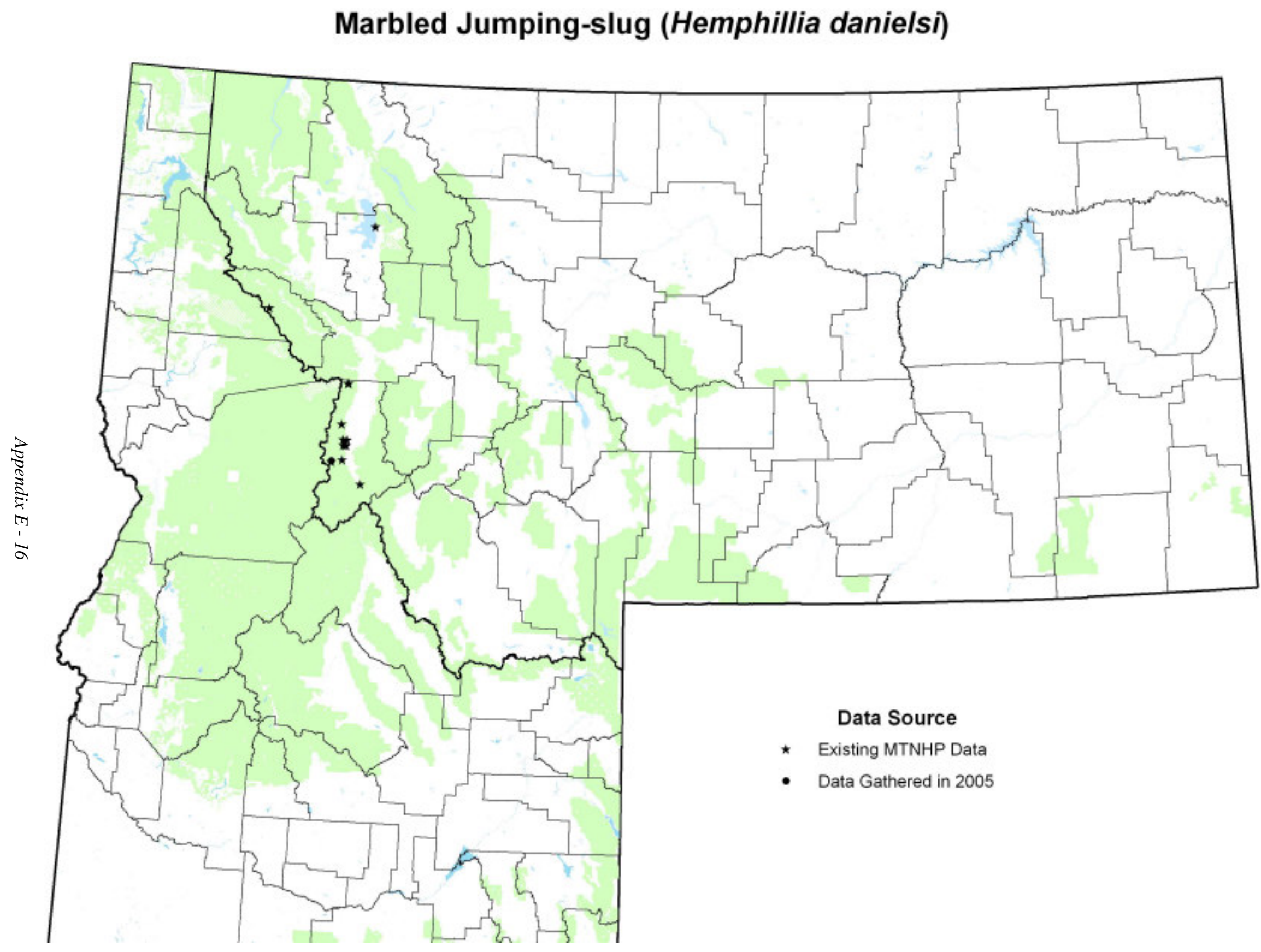




\section{Pygmy Slug (Kootenaia burkei)}

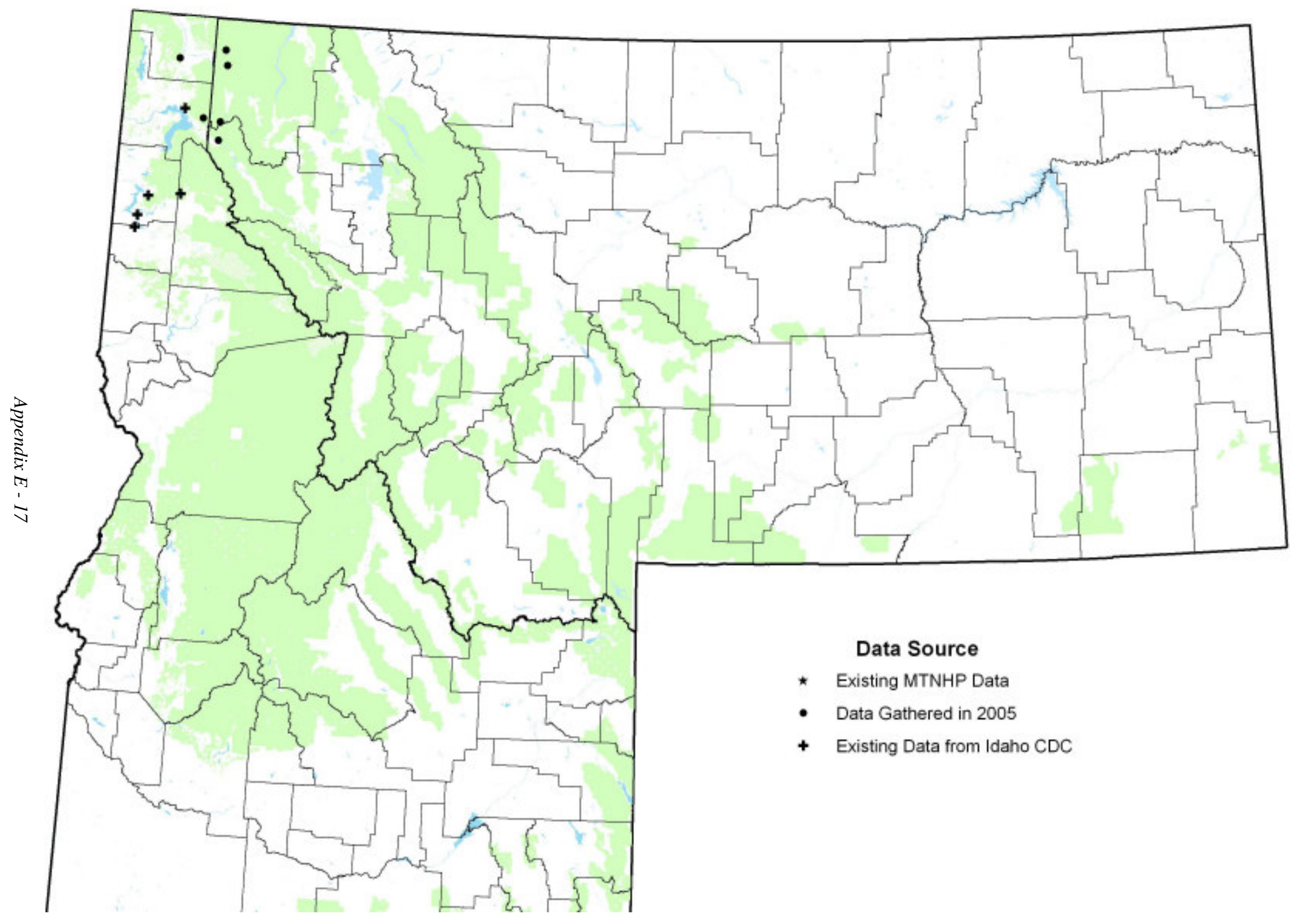




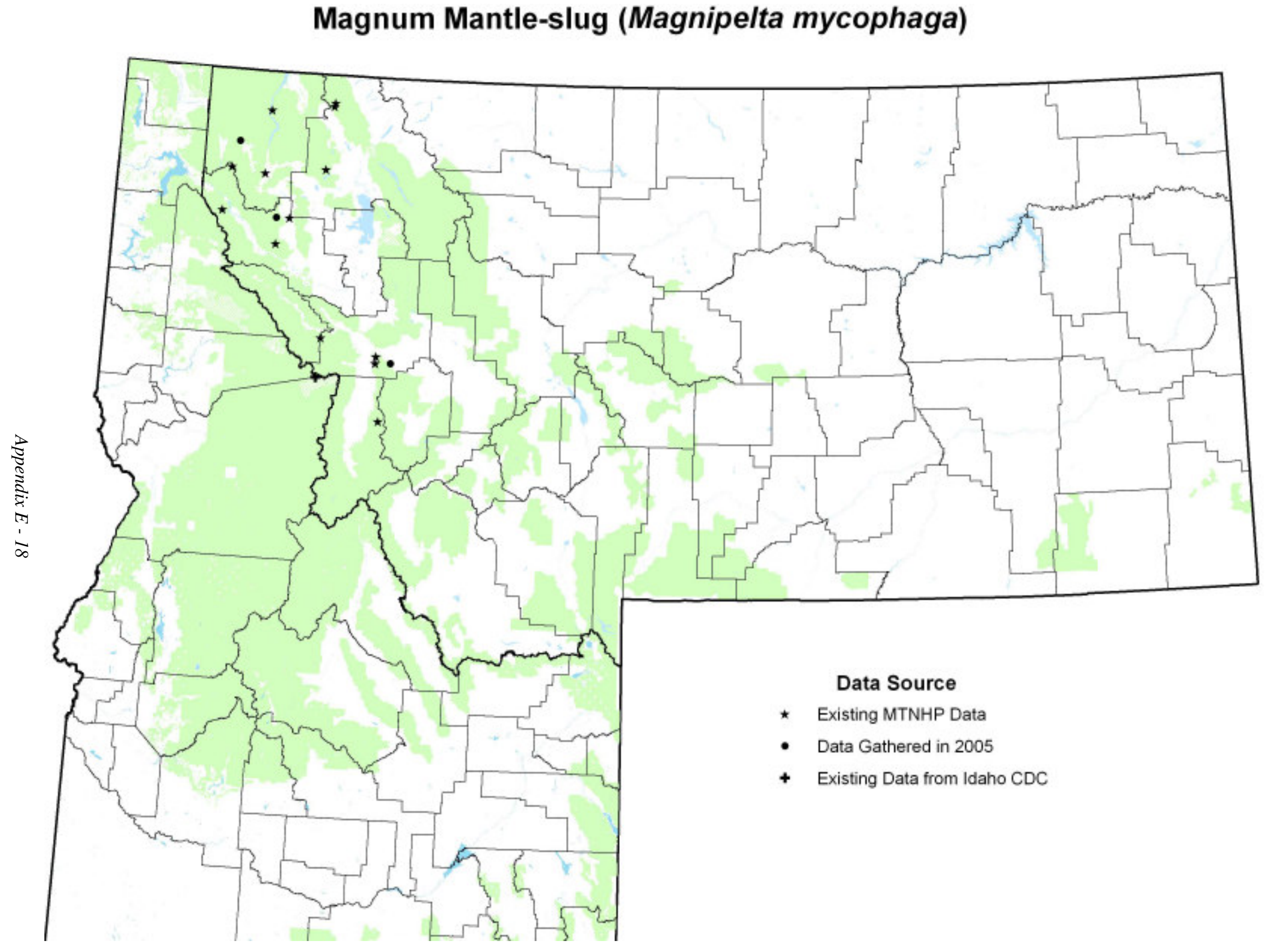


Alpine Mountainsnail (Oreohelix alpina)

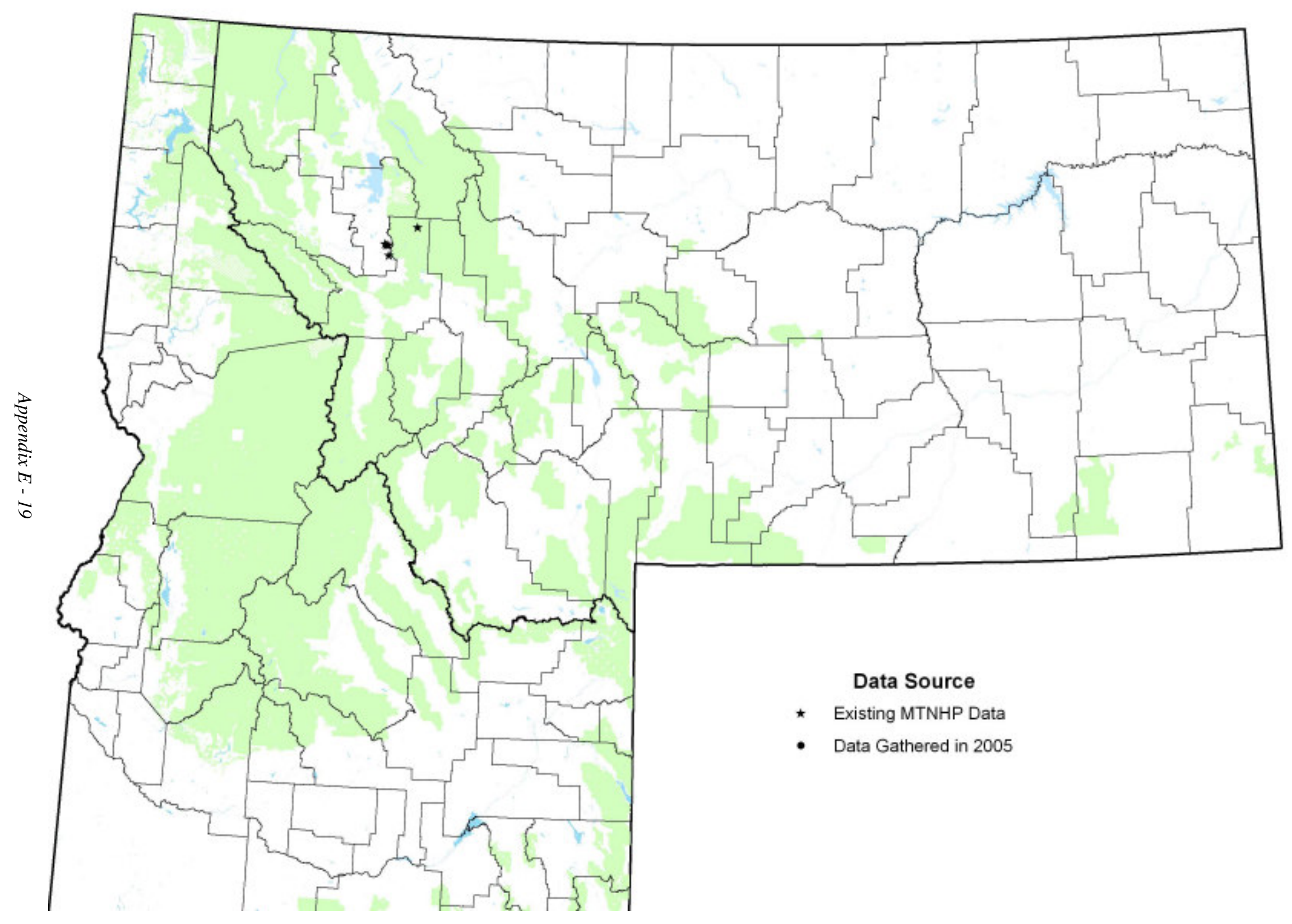




\section{Bitterroot Mountainsnail (Oreohelix amariradix)}

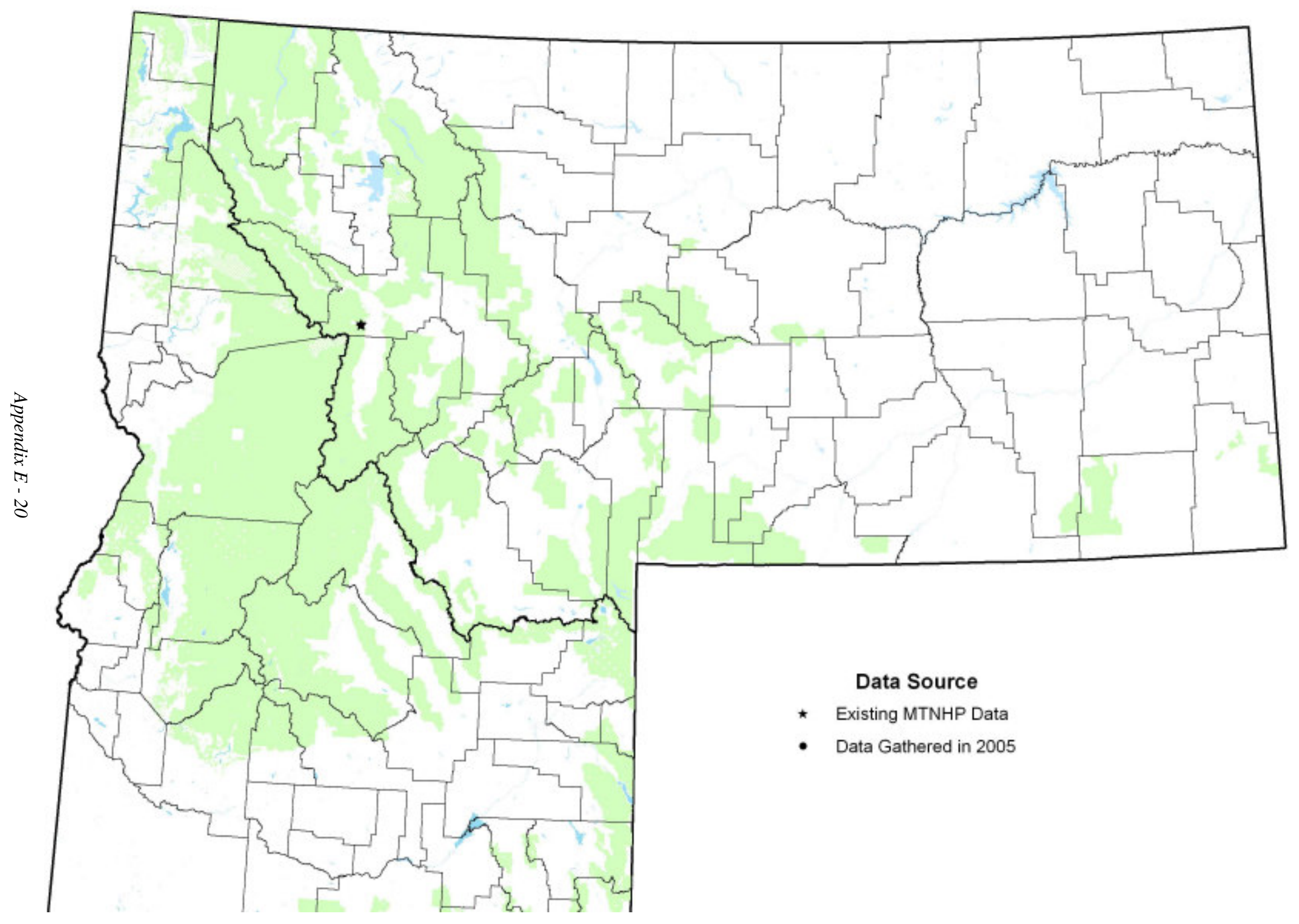




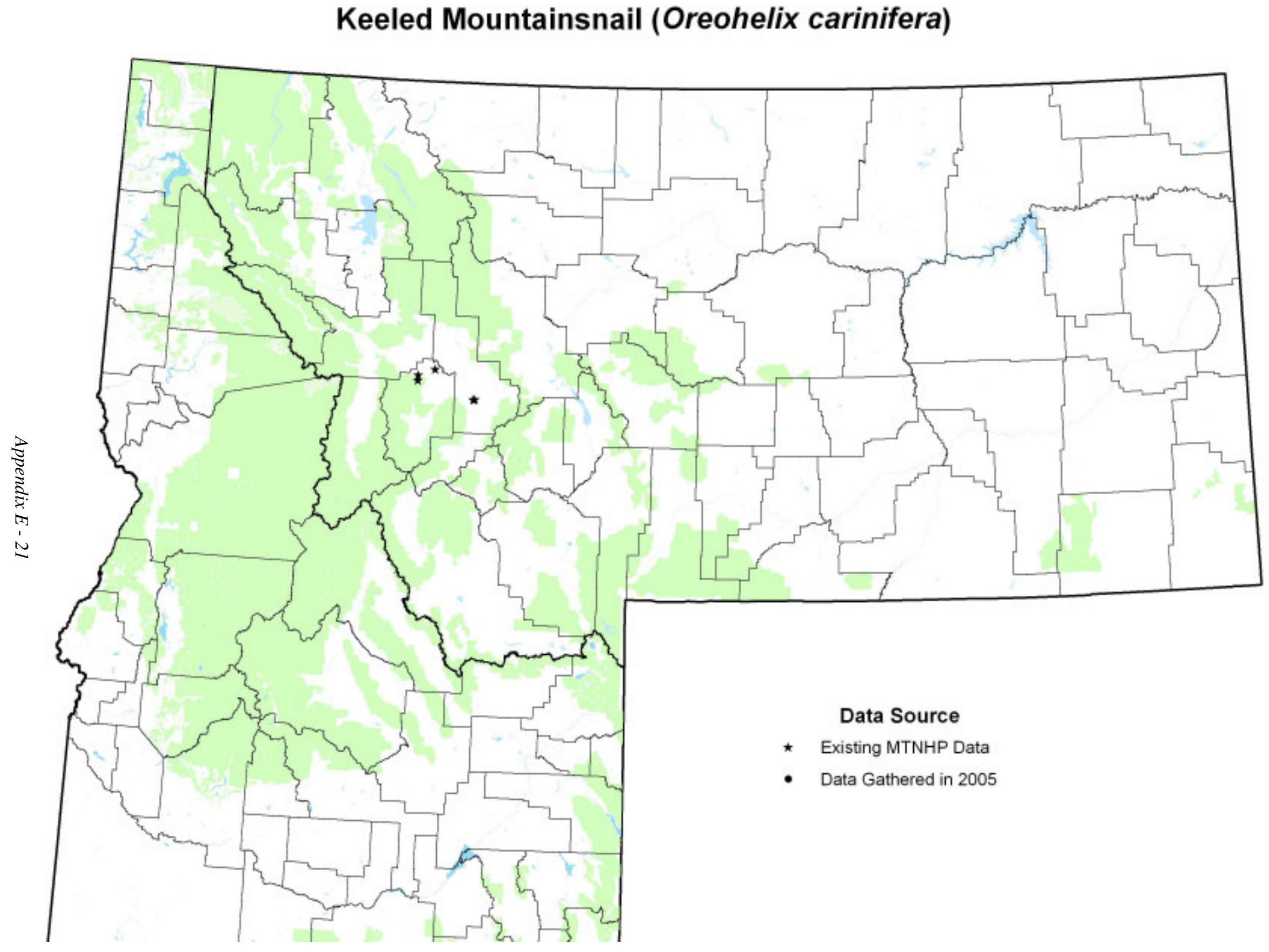




\section{Carinate Mountainsnail (Oreohelix elrodi)}

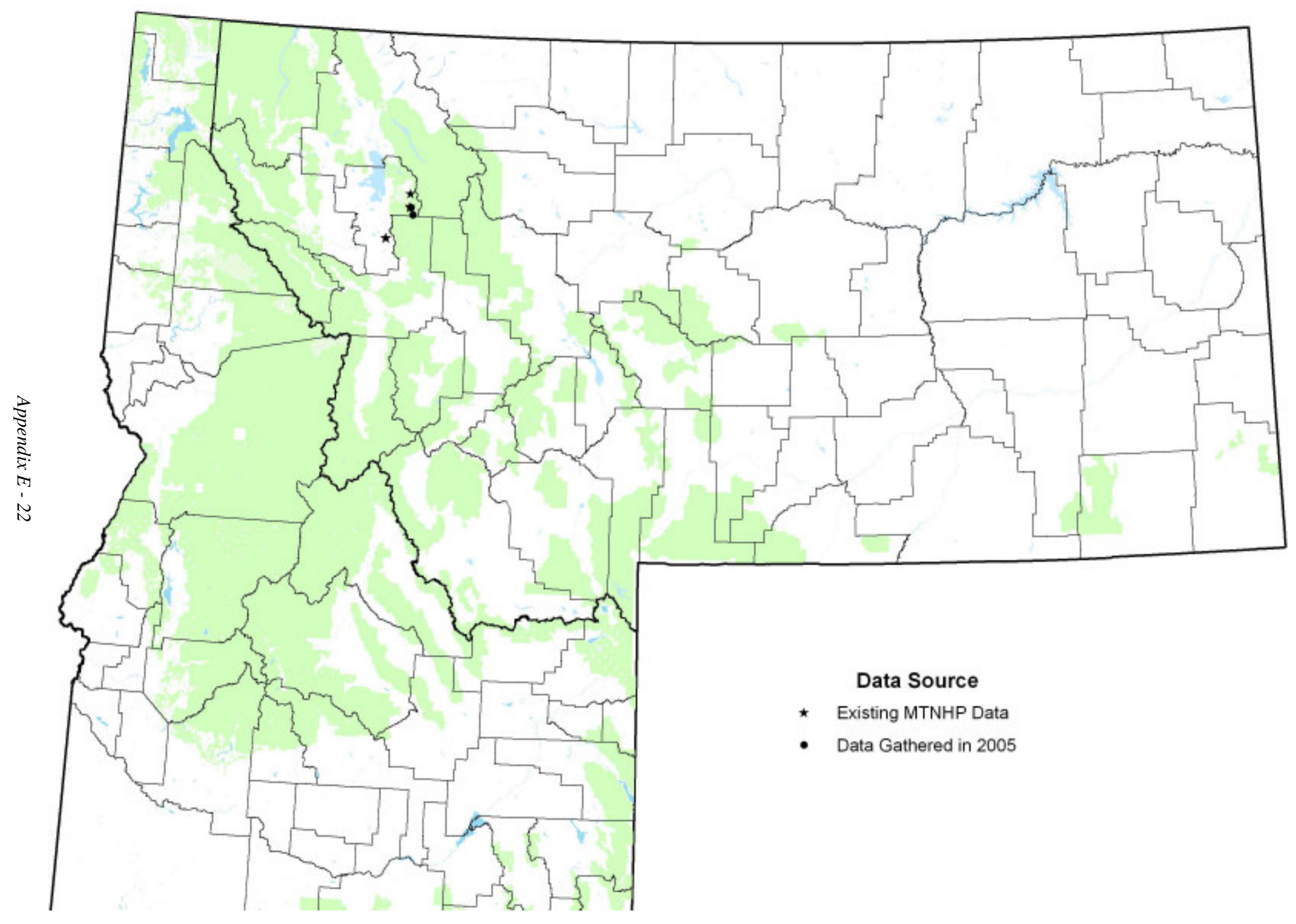




\section{Seven Devils Mountainsnail (Oreohelix hammeri)}

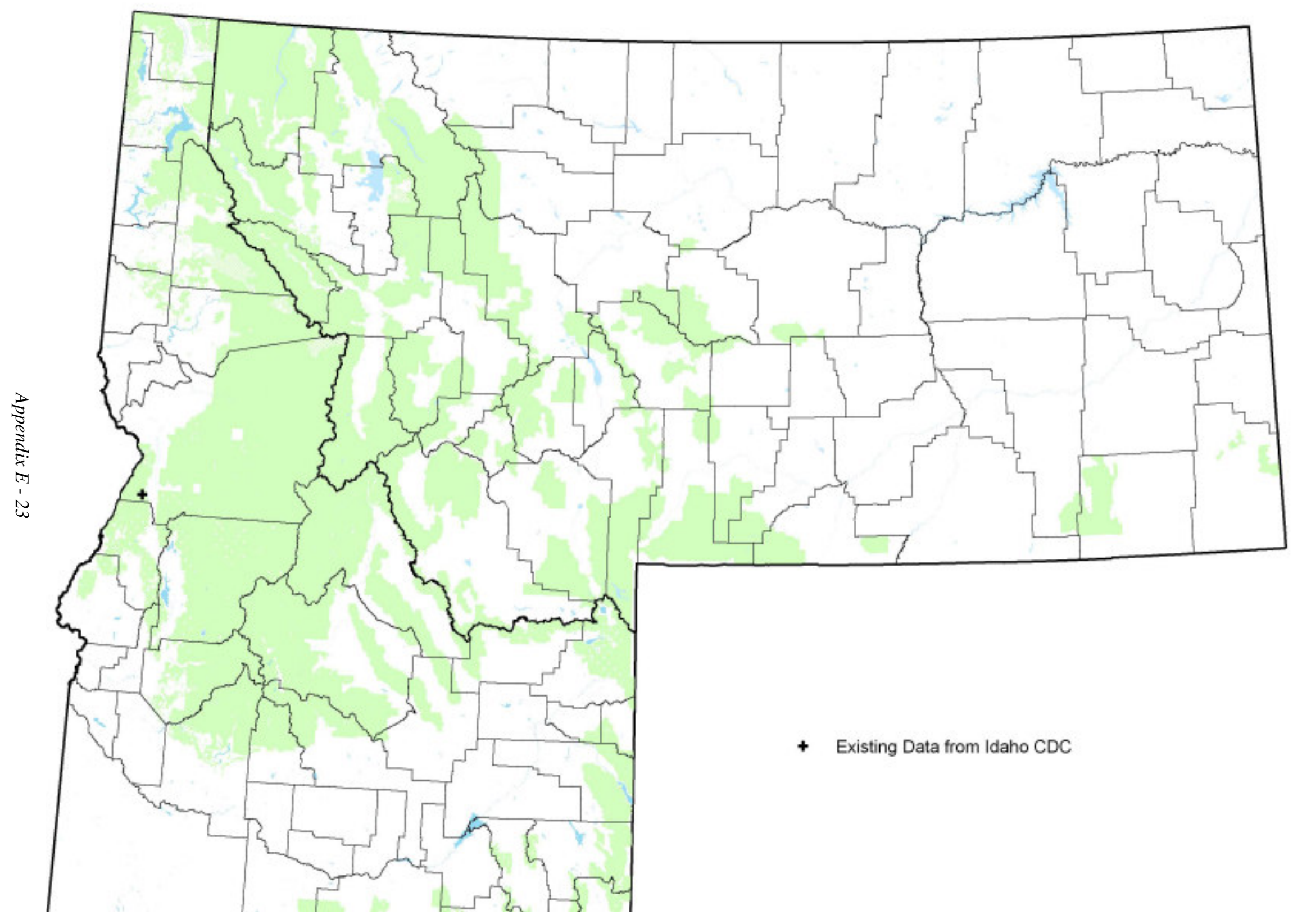


Costate Mountainsnail (Oreohelix idahoensis)

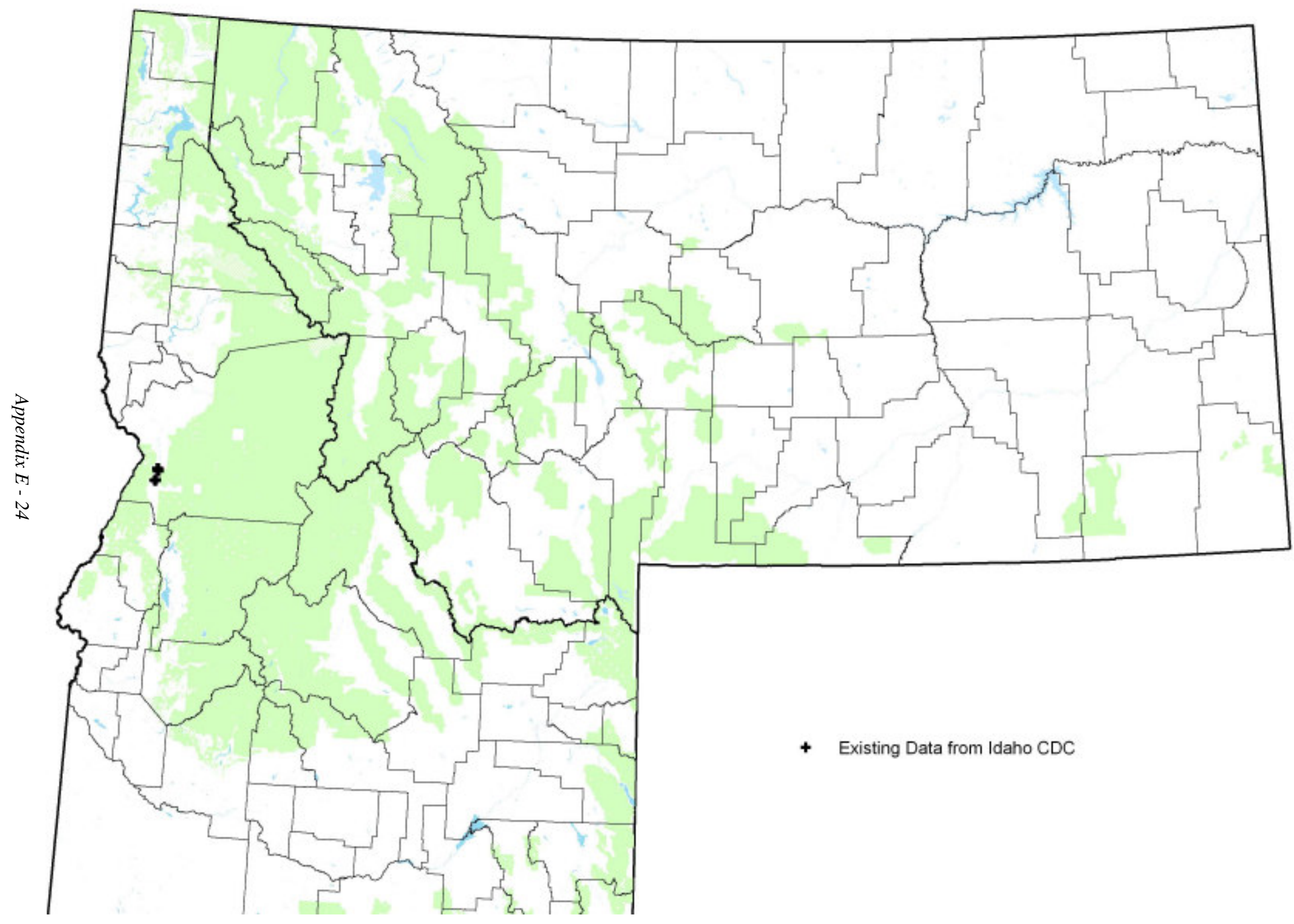




\section{Deep Slide Mountainsnail (Oreohelix intersum)}

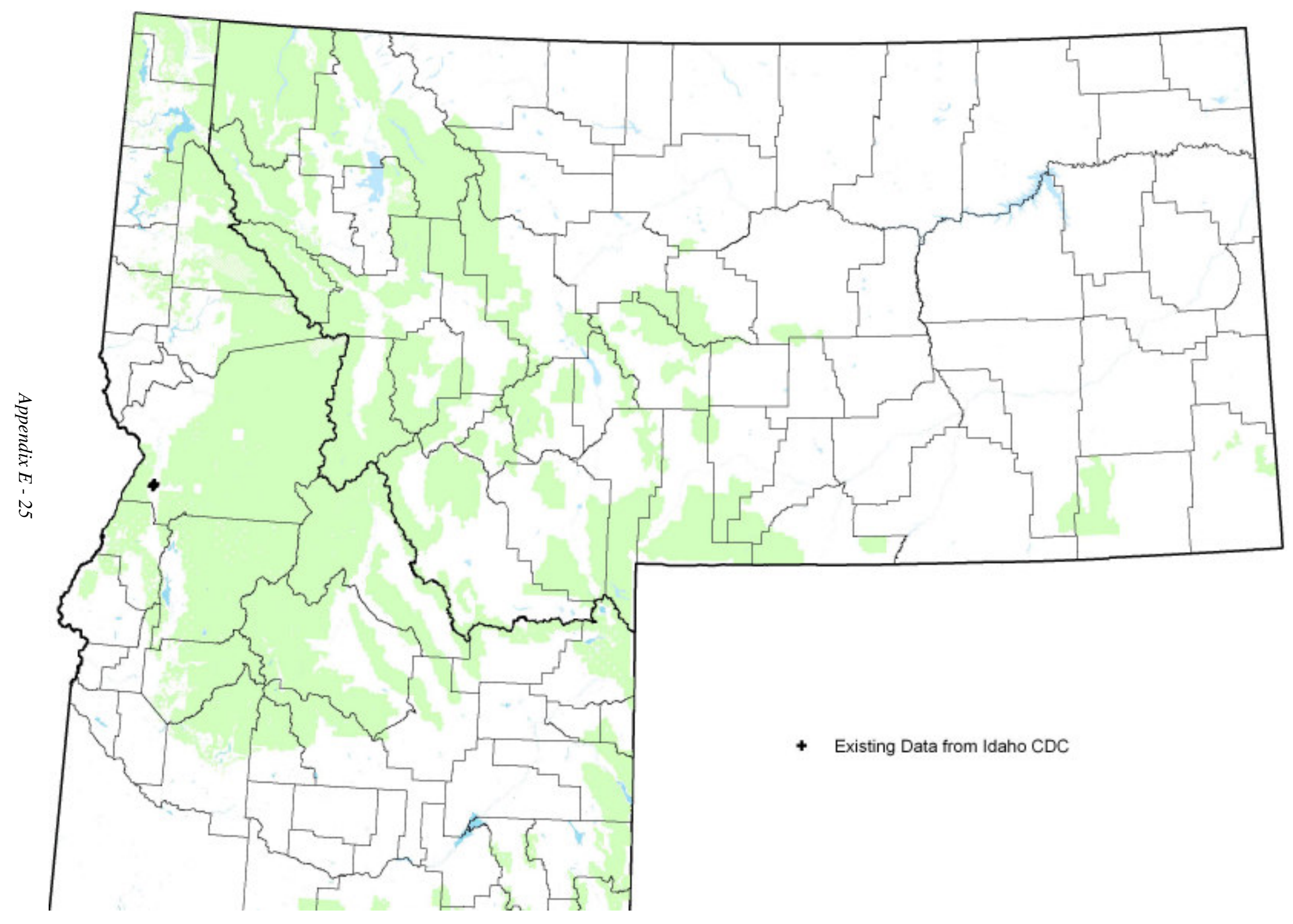


Boulder Pile Mountainsnail (Oreohelix jugalis)

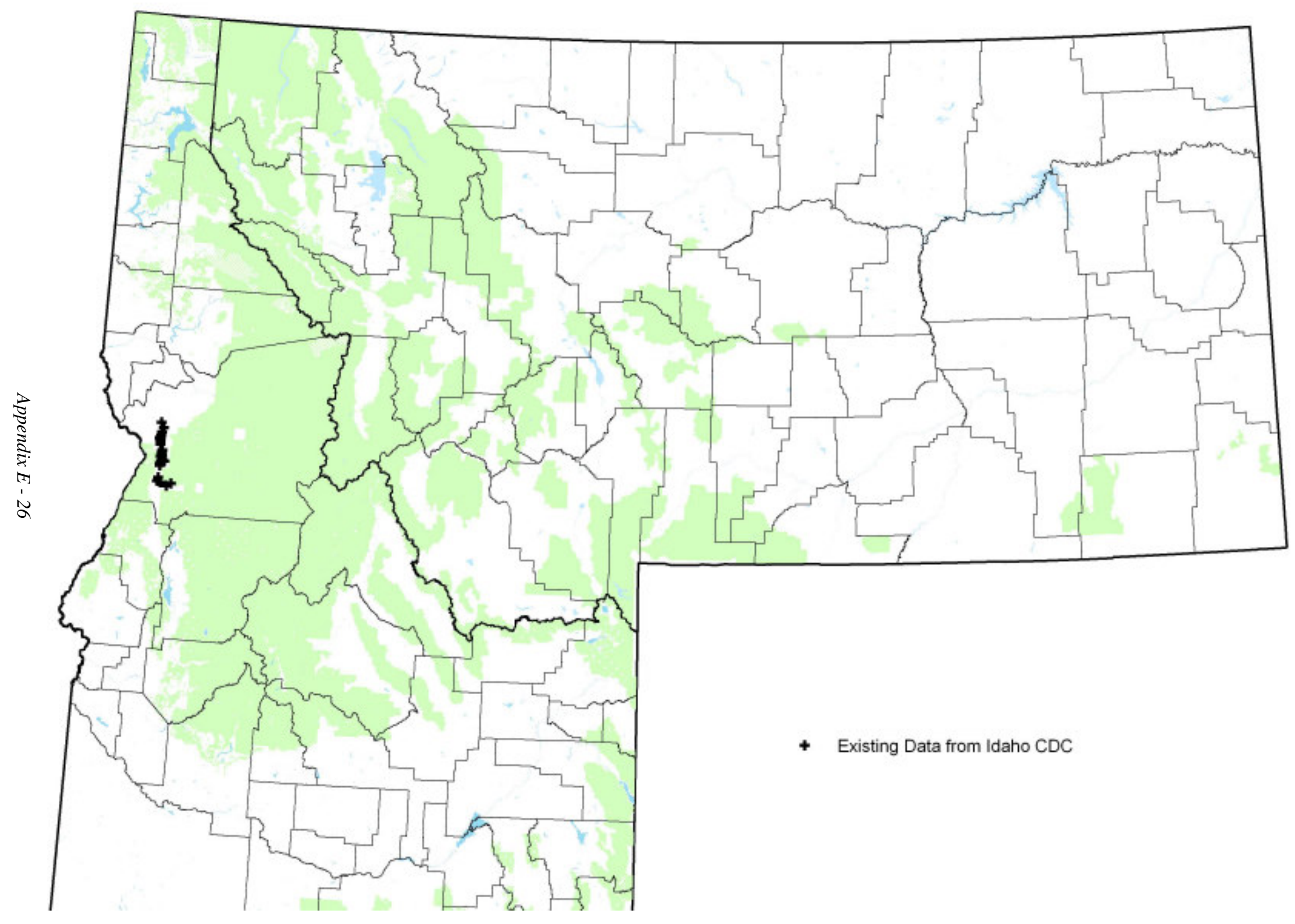




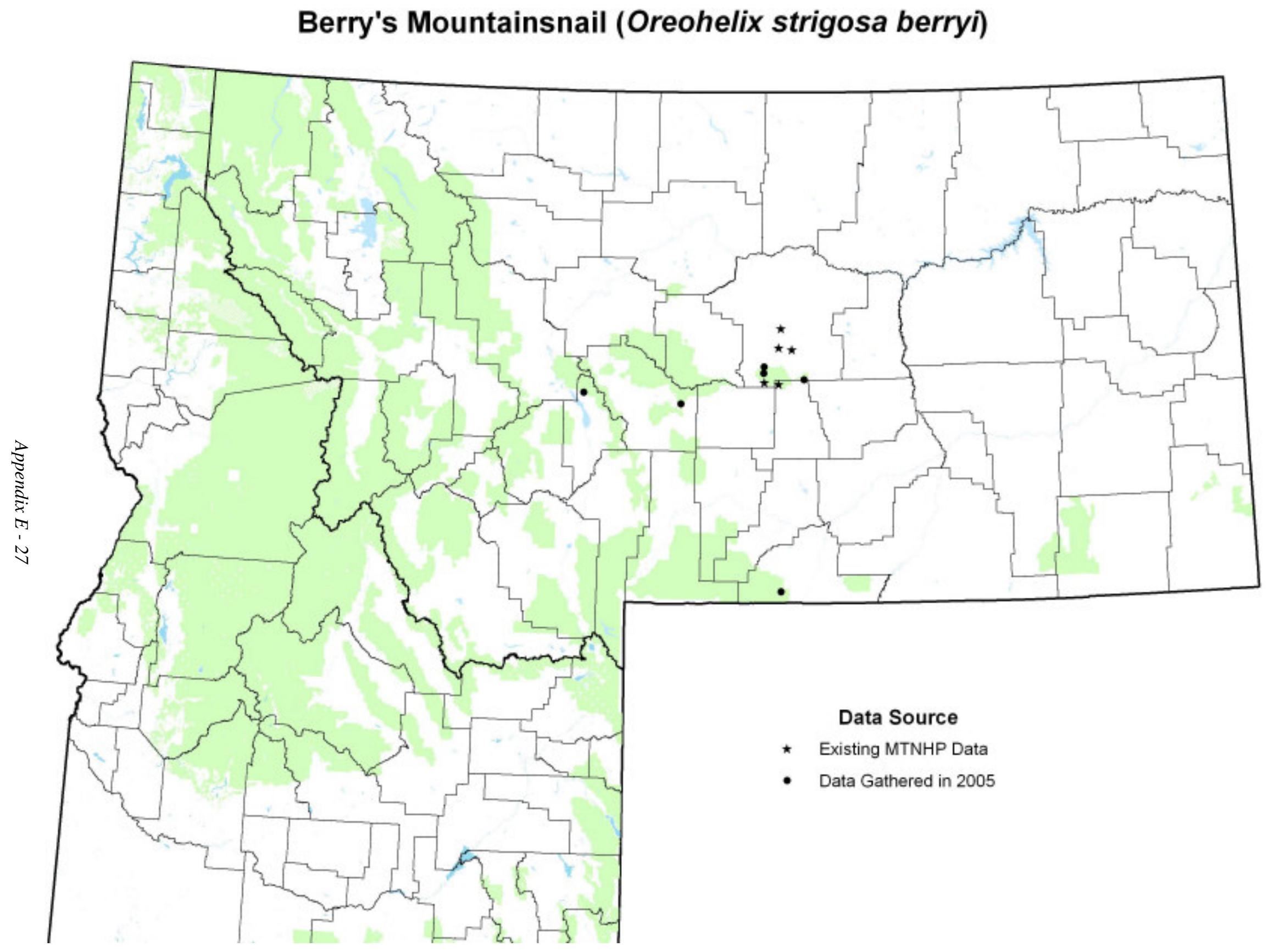




\section{Striate Mountainsnail (Oreohelix strigosa goniogyra)}

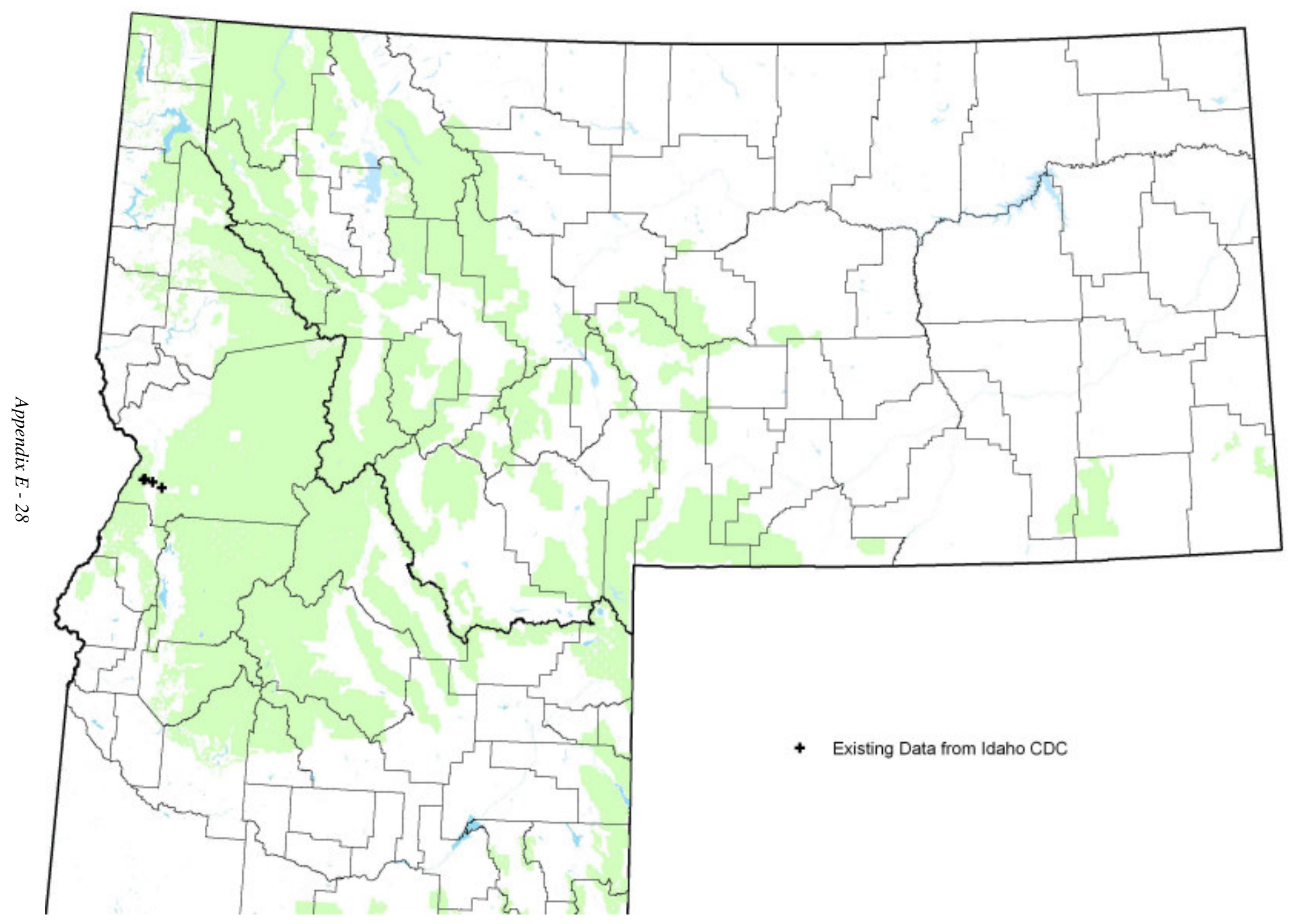




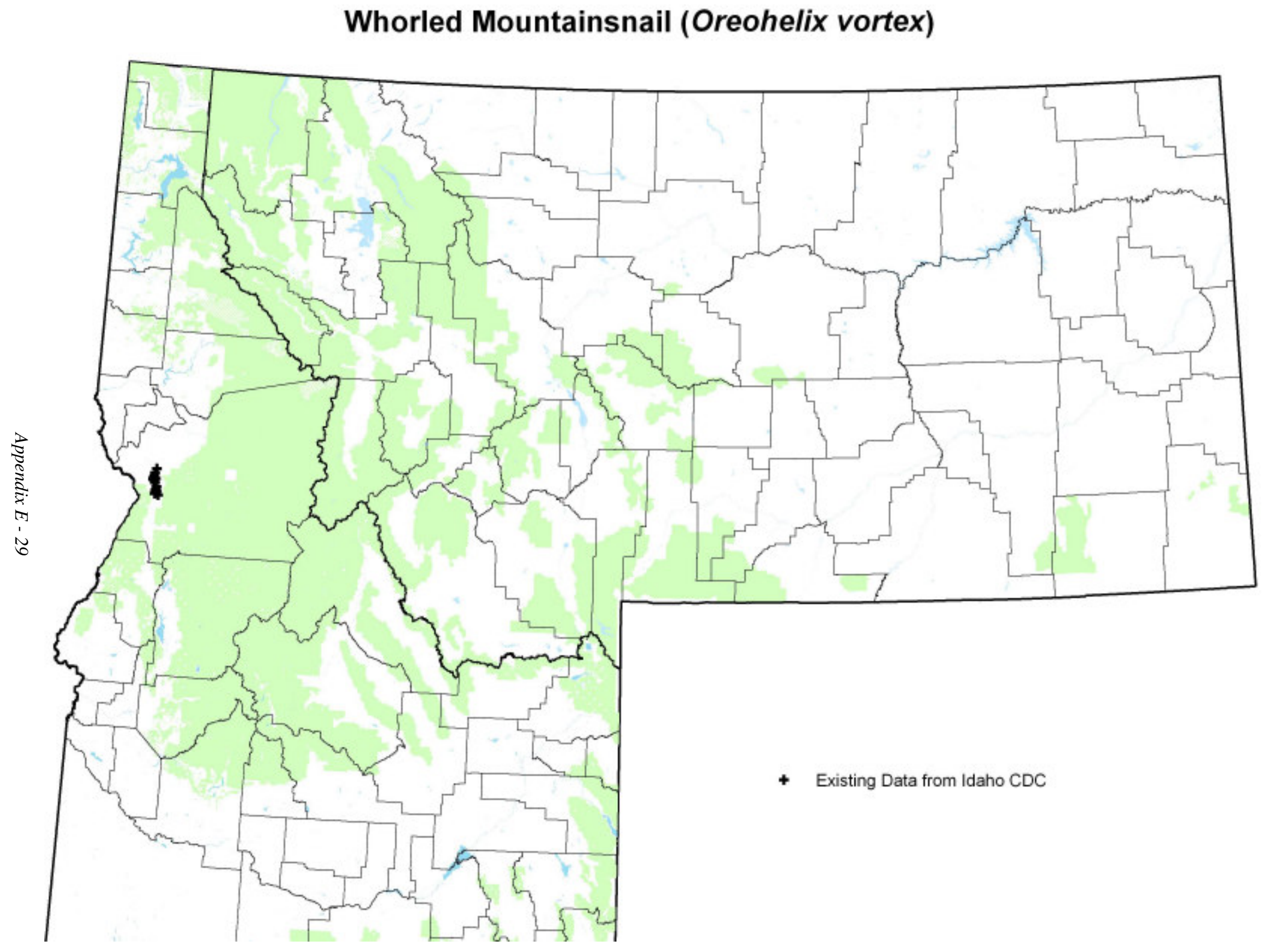




\section{Lava Rock Mountainsnail (Oreohelix waltoni)}

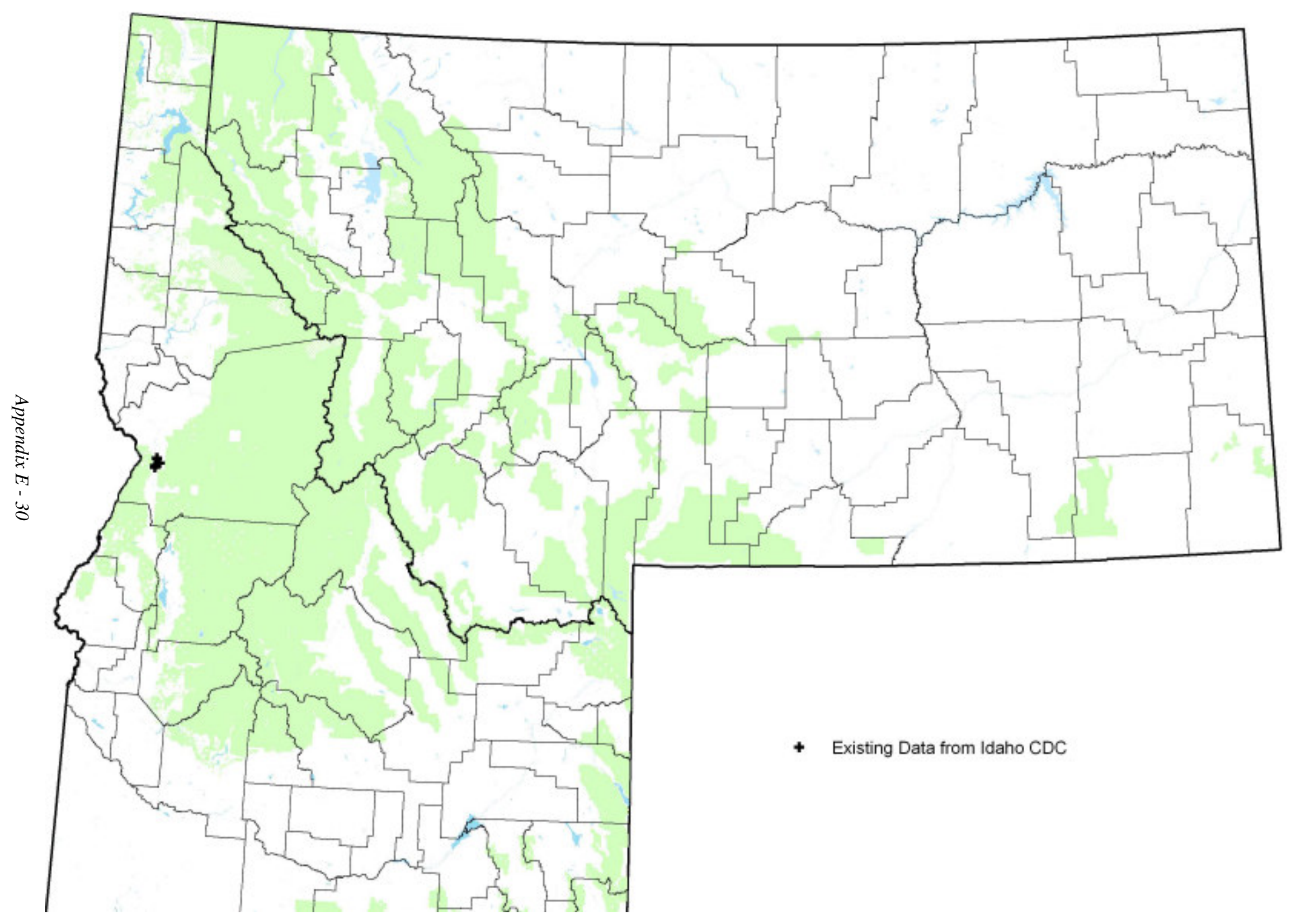




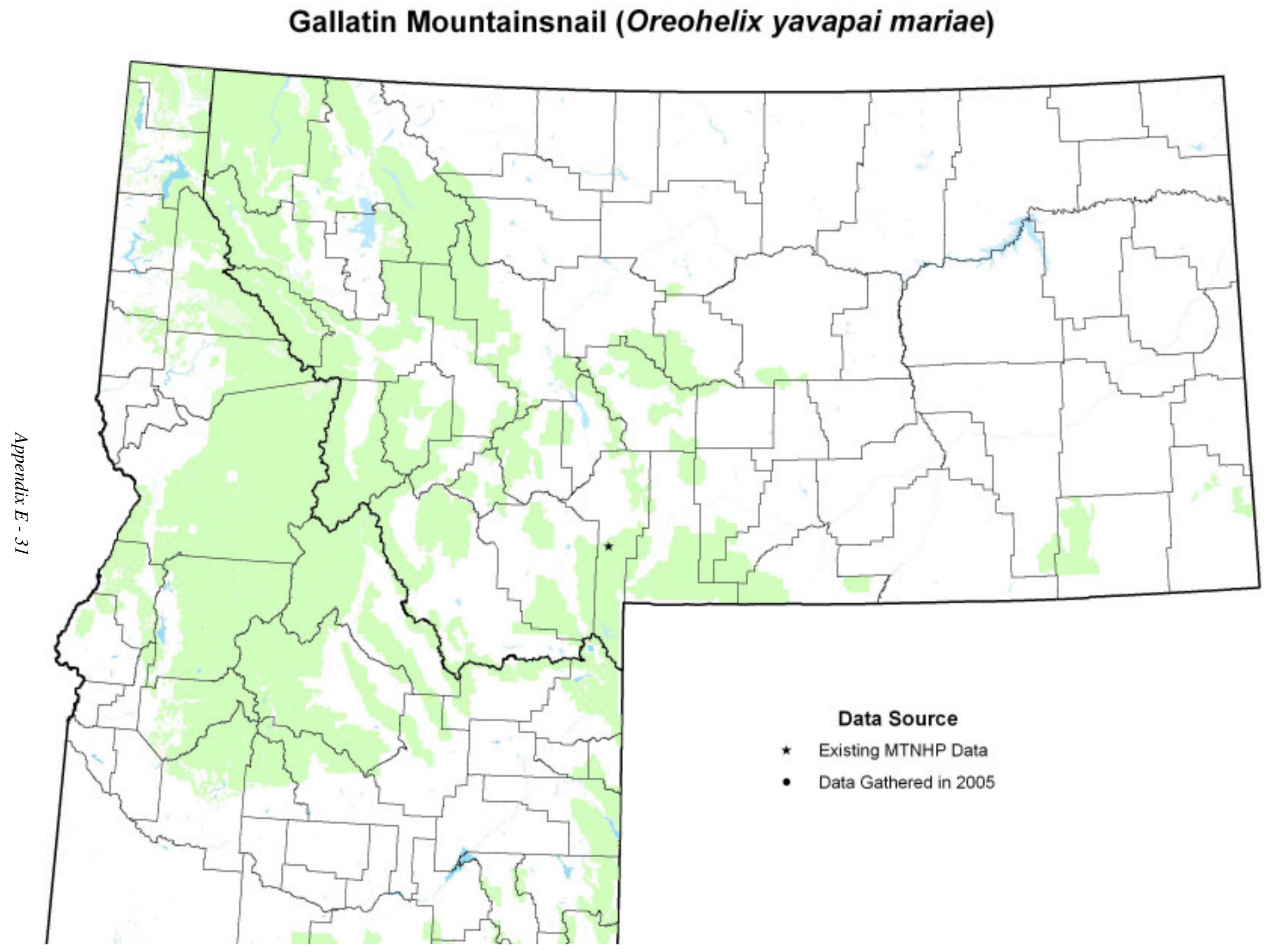




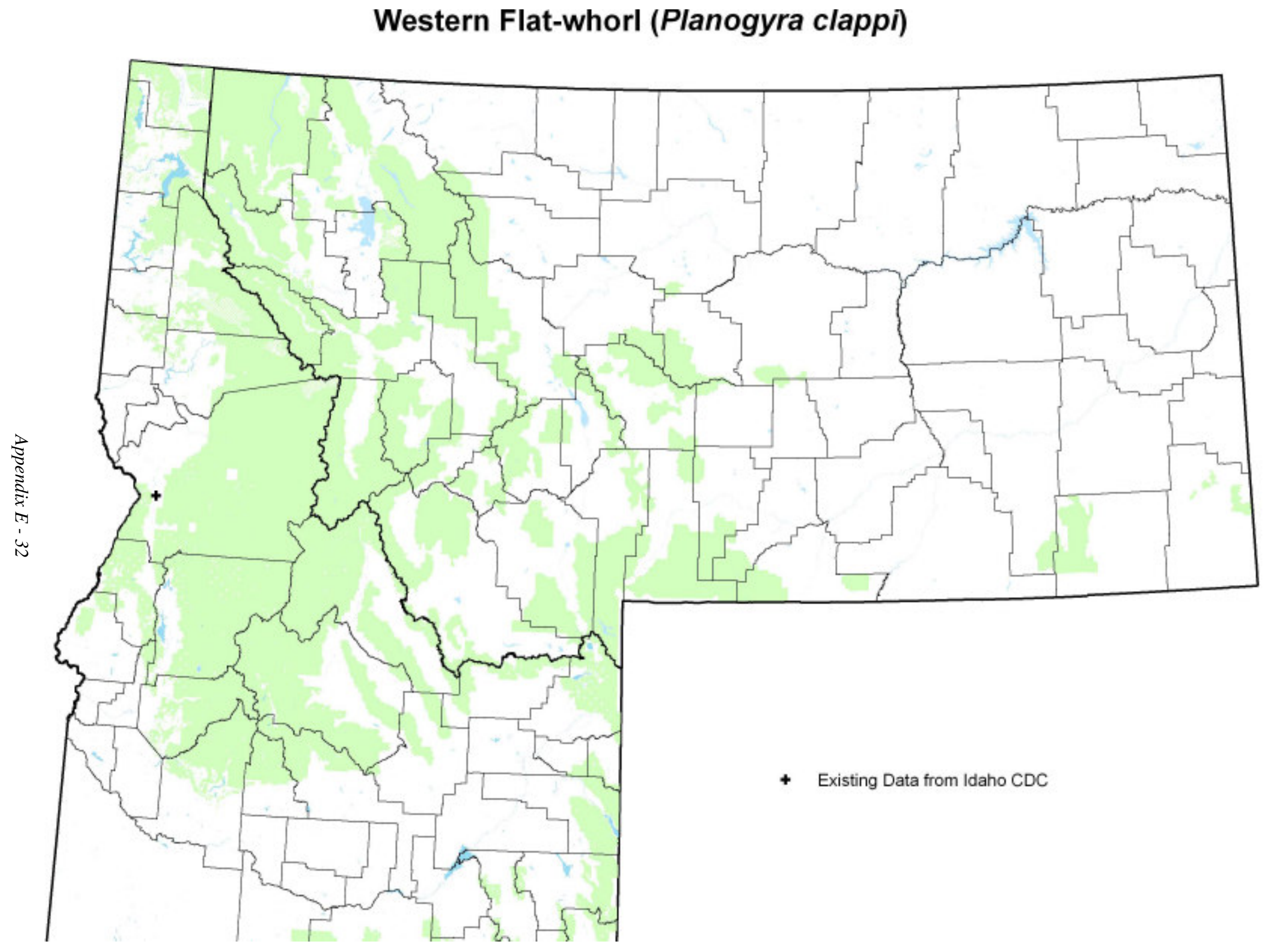


Humped Coin (Polygyrella polygyrella)

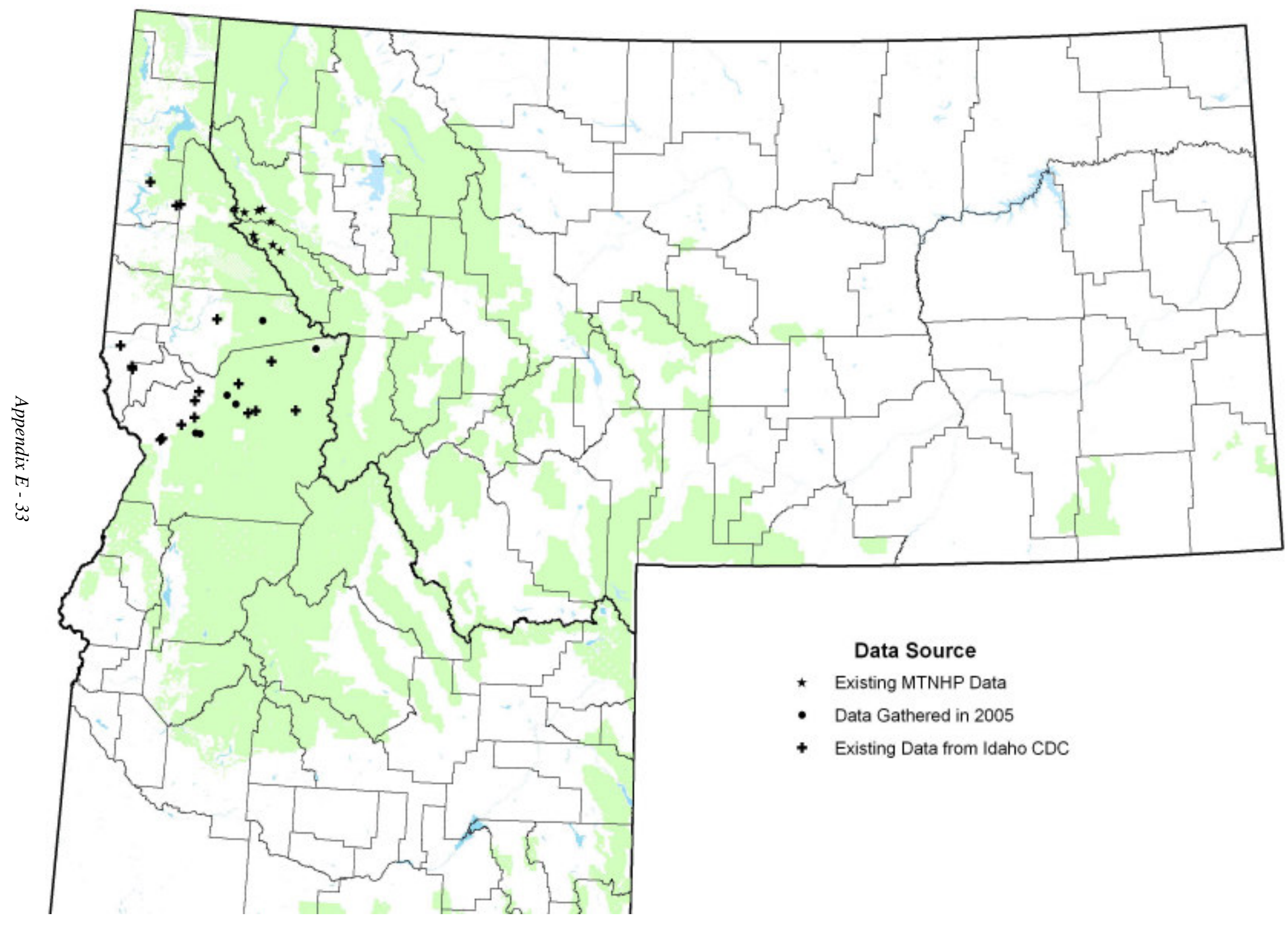


Thinlip Tightcoil (Pristiloma idahoense)

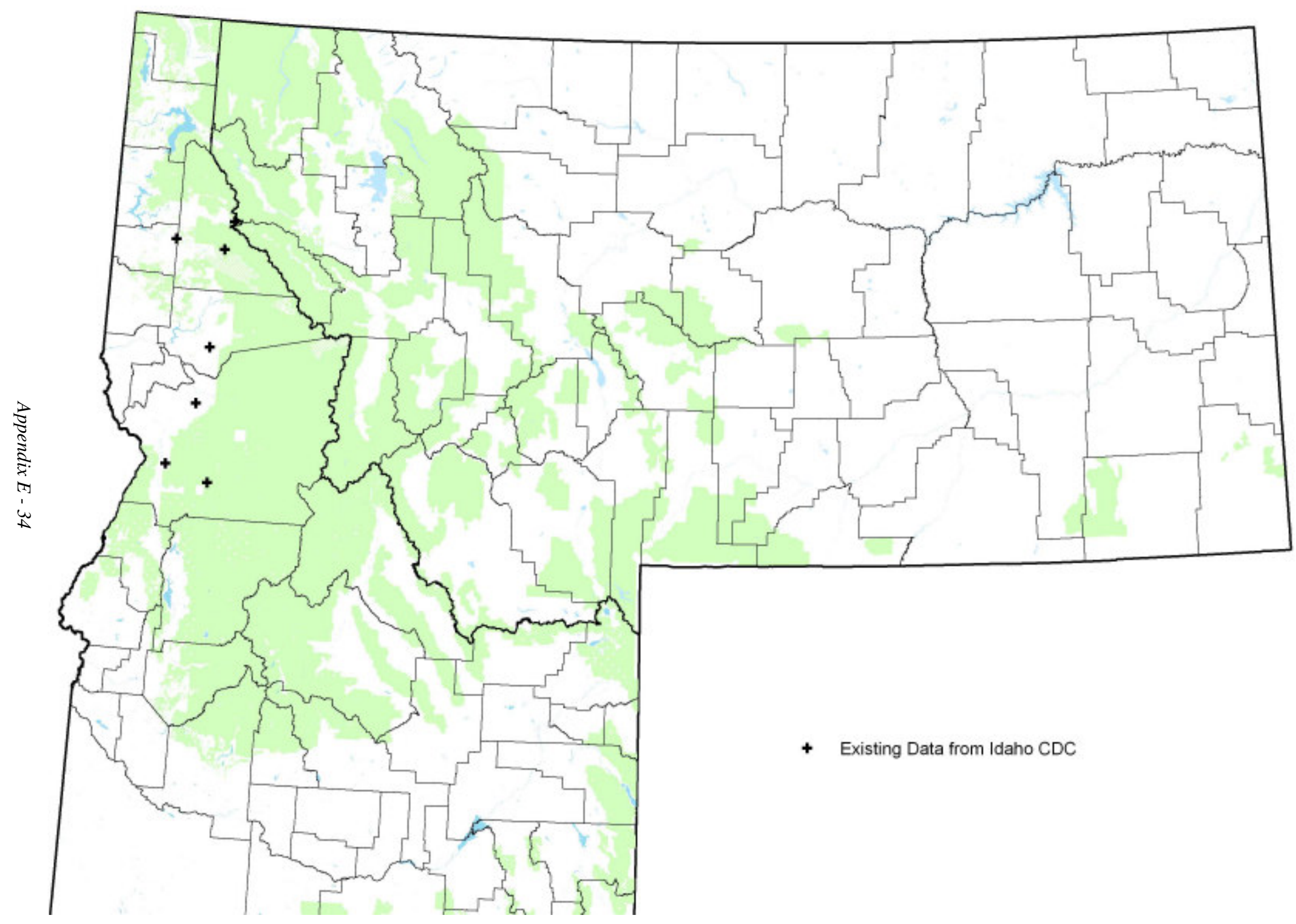




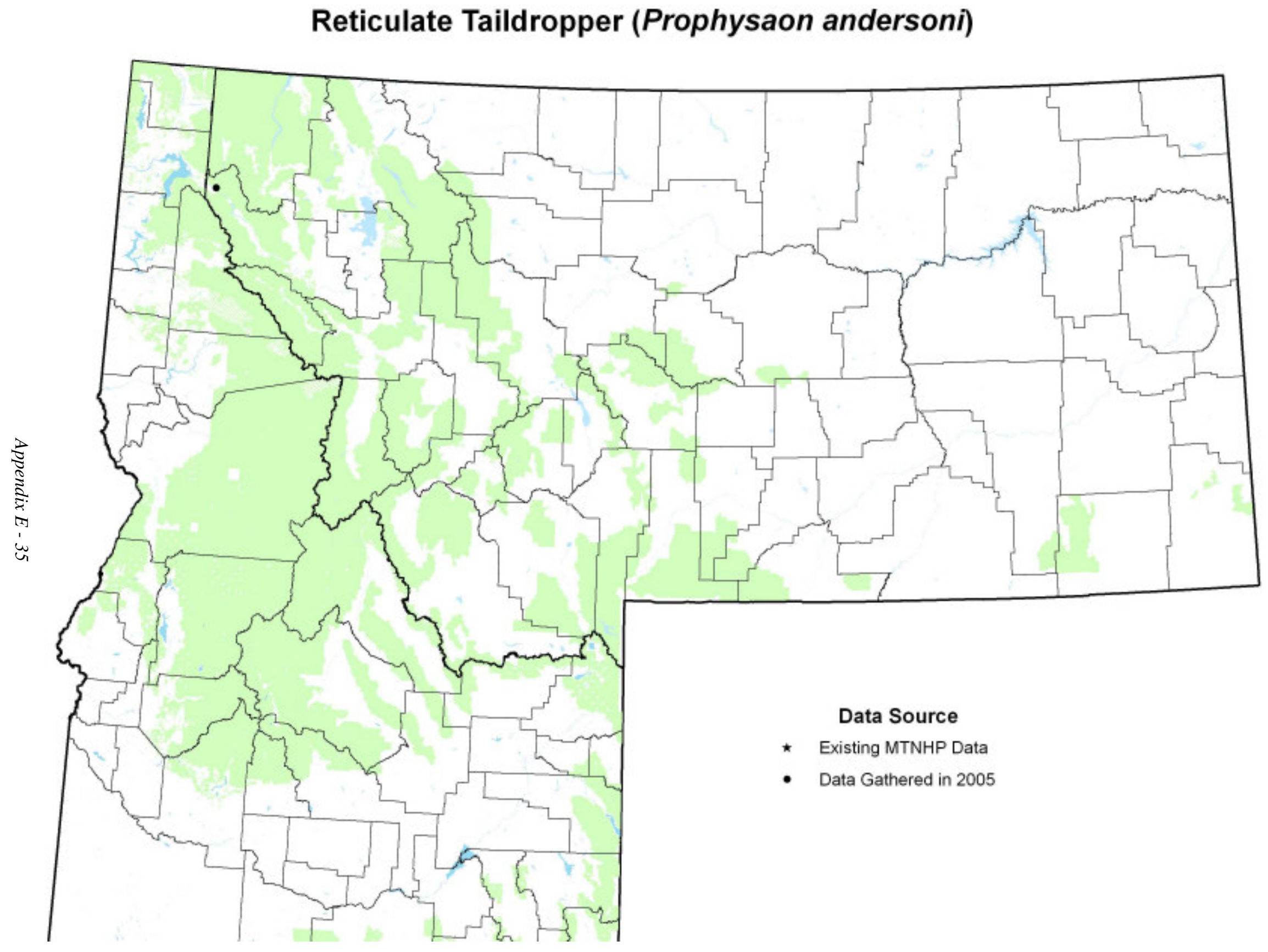




\section{Smoky Taildropper (Prophysaon humile)}

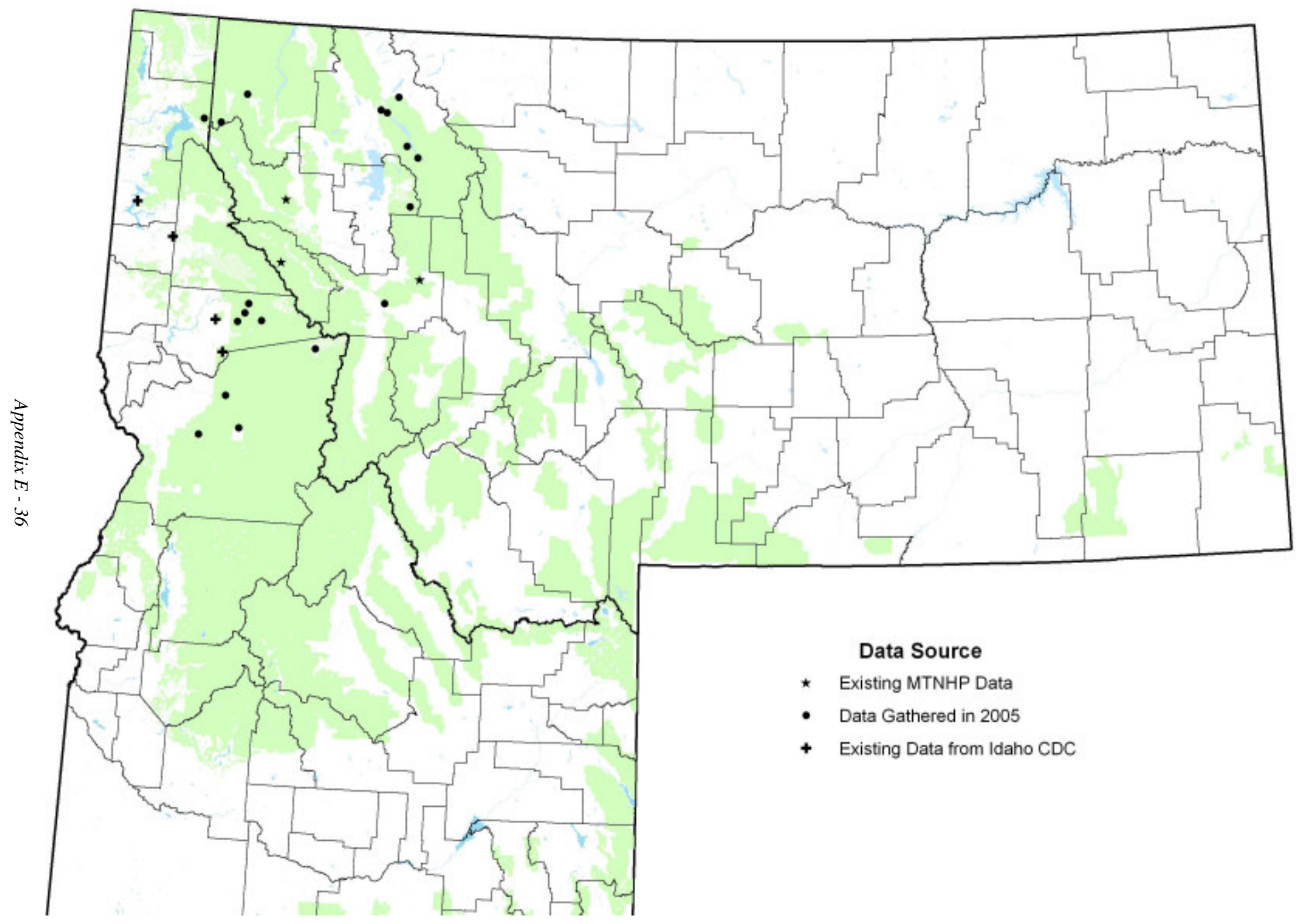




\section{Fir Pinwheel (Radiodiscus abietum)}

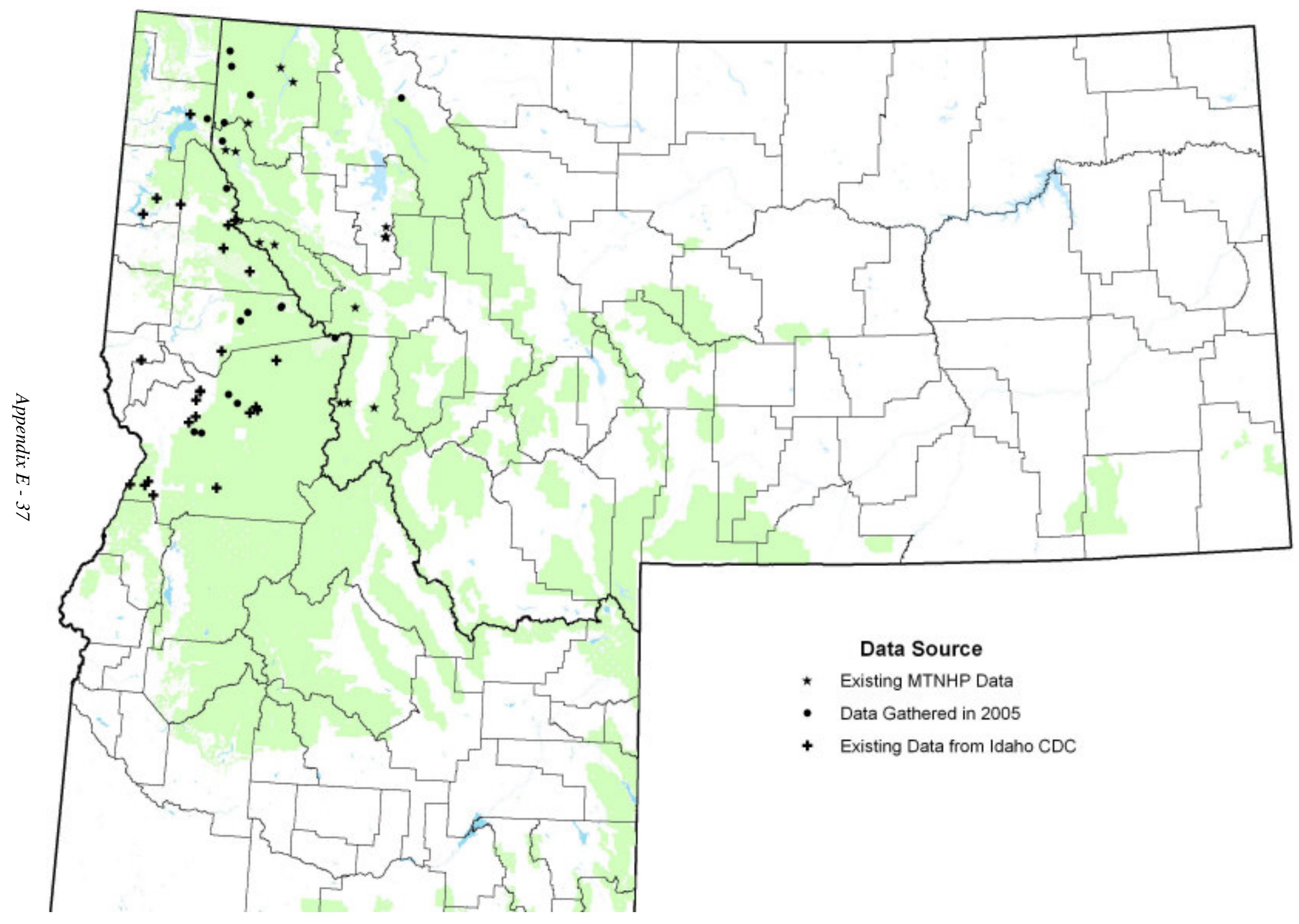




\section{Lyre Mantleslug (Udosarx lyrata)}

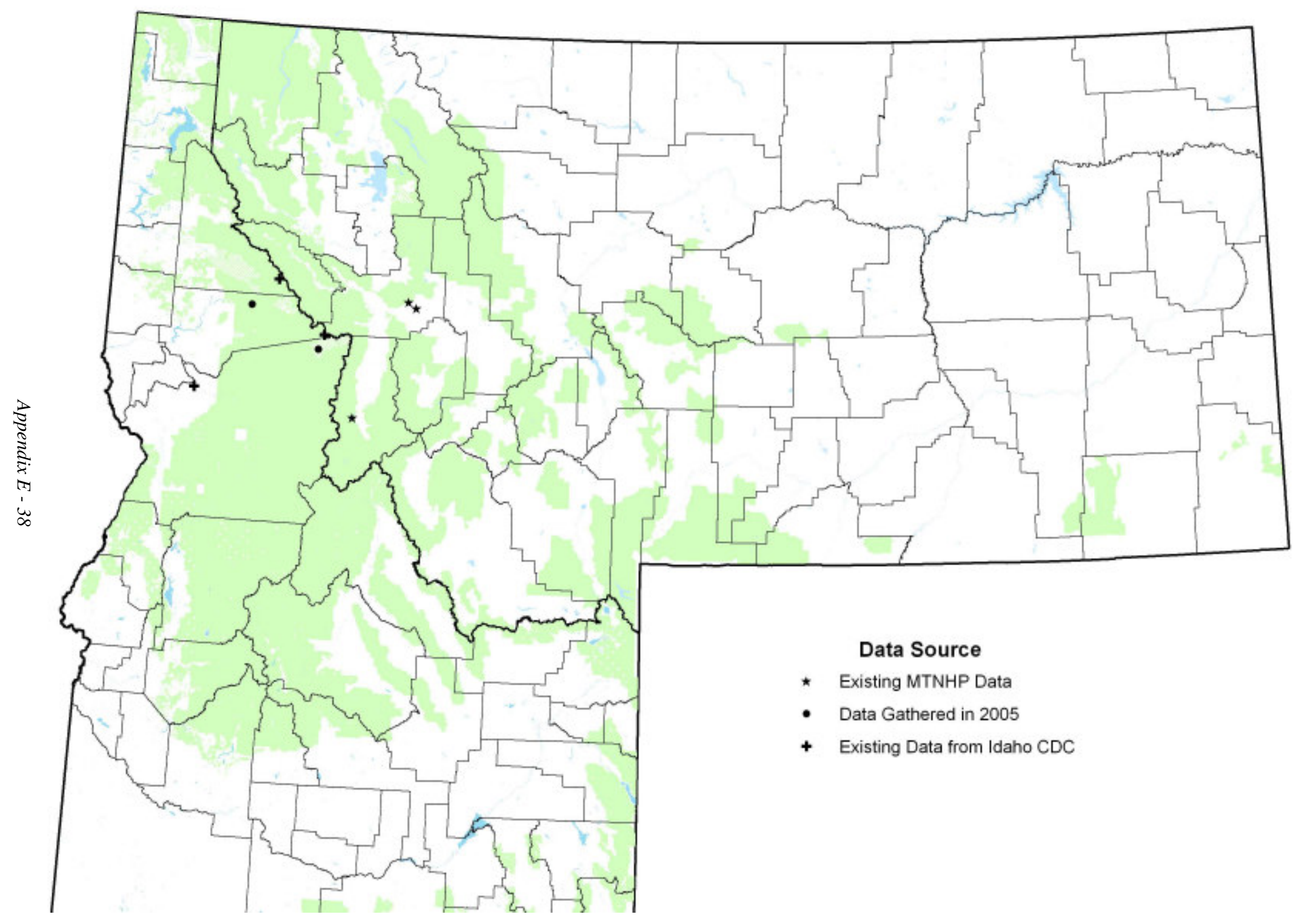




\section{Sheathed Slug (Zacoleus idahoensis)}

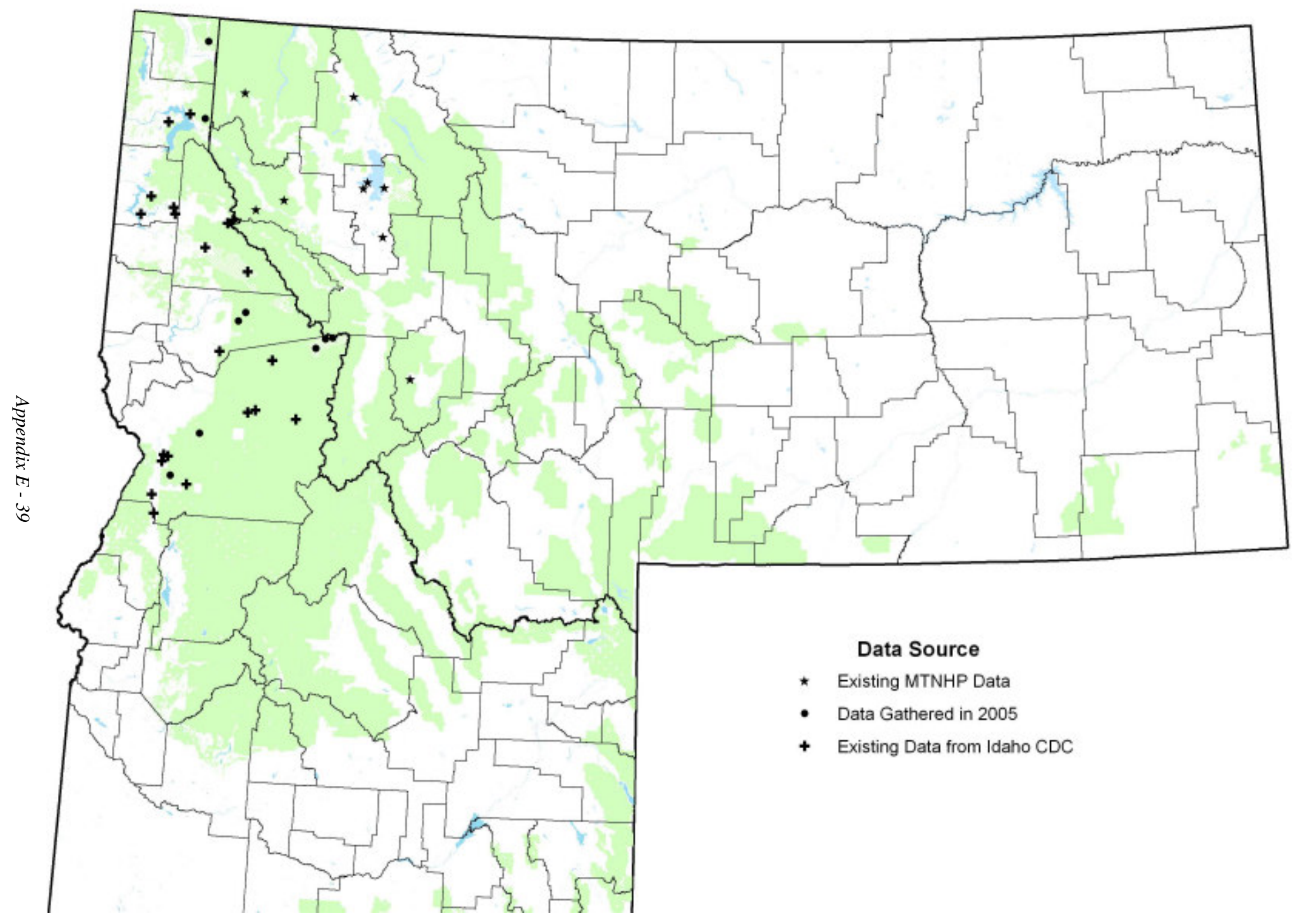





\section{Appendix F. Distribution Maps for Non-SOC Land Mollusks ON USFS REgION 1 LANDS}





\section{Idaho Forestsnail (Allogona ptycophora)}

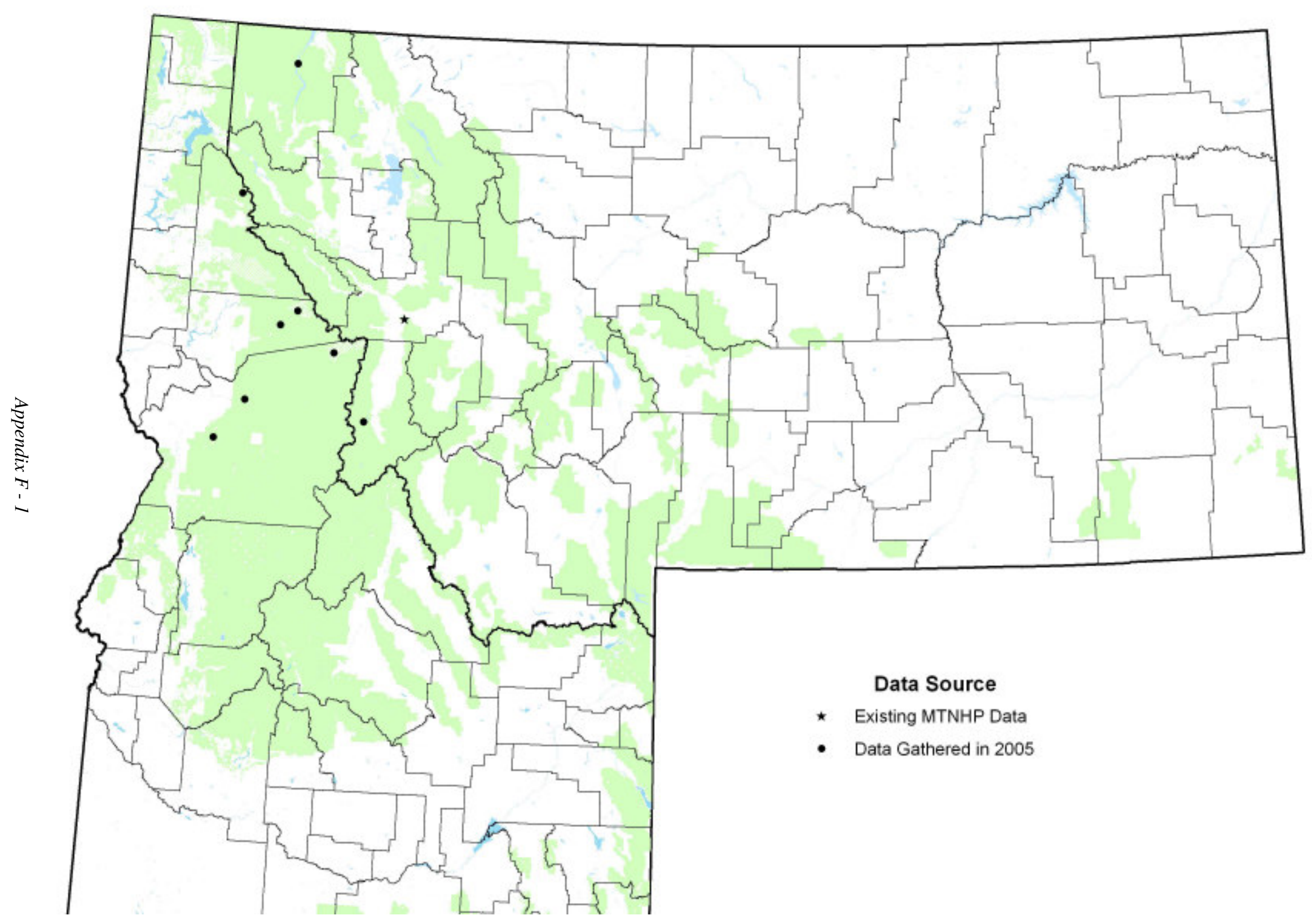




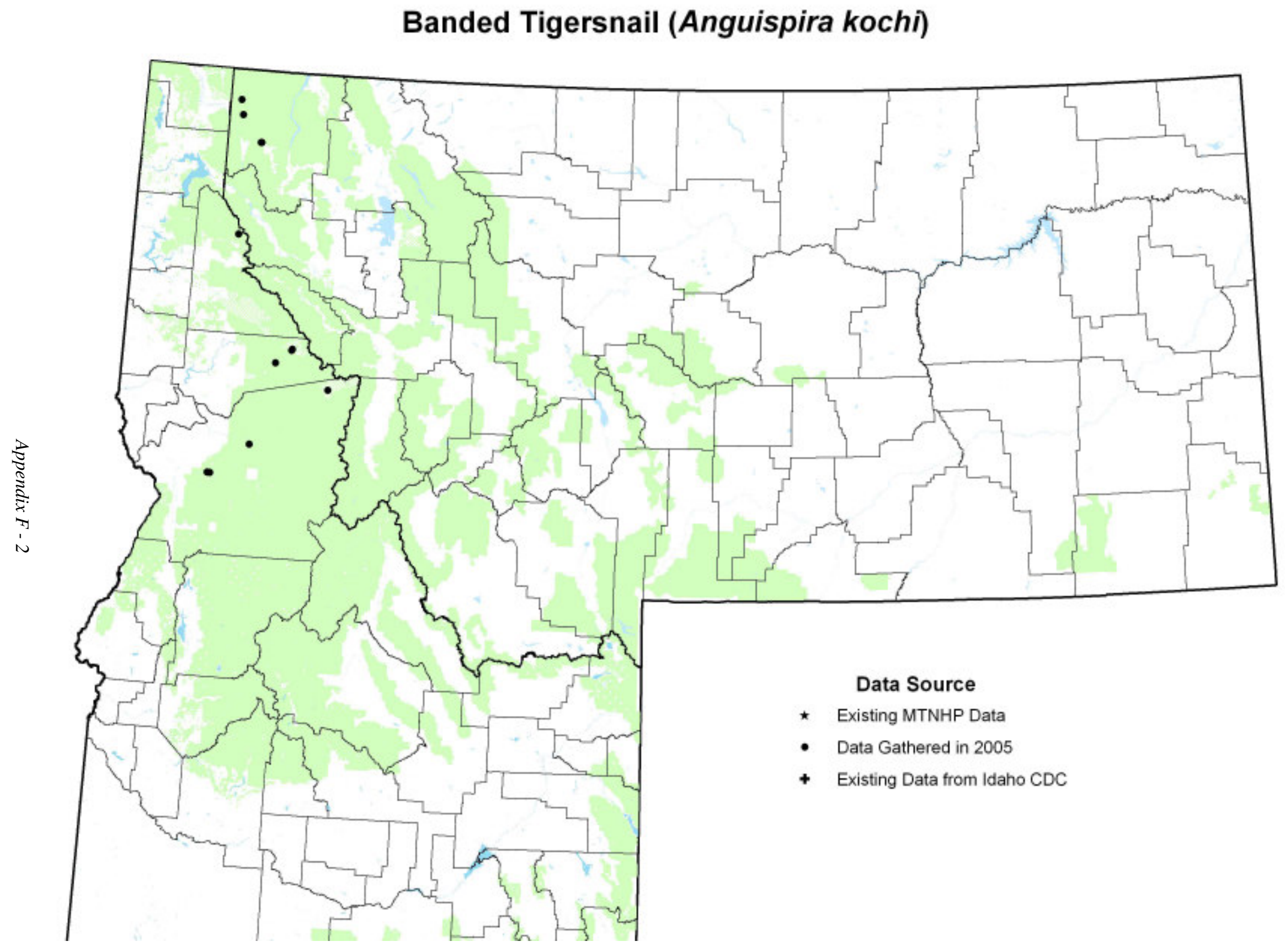


Mellow Column (Columella columella)

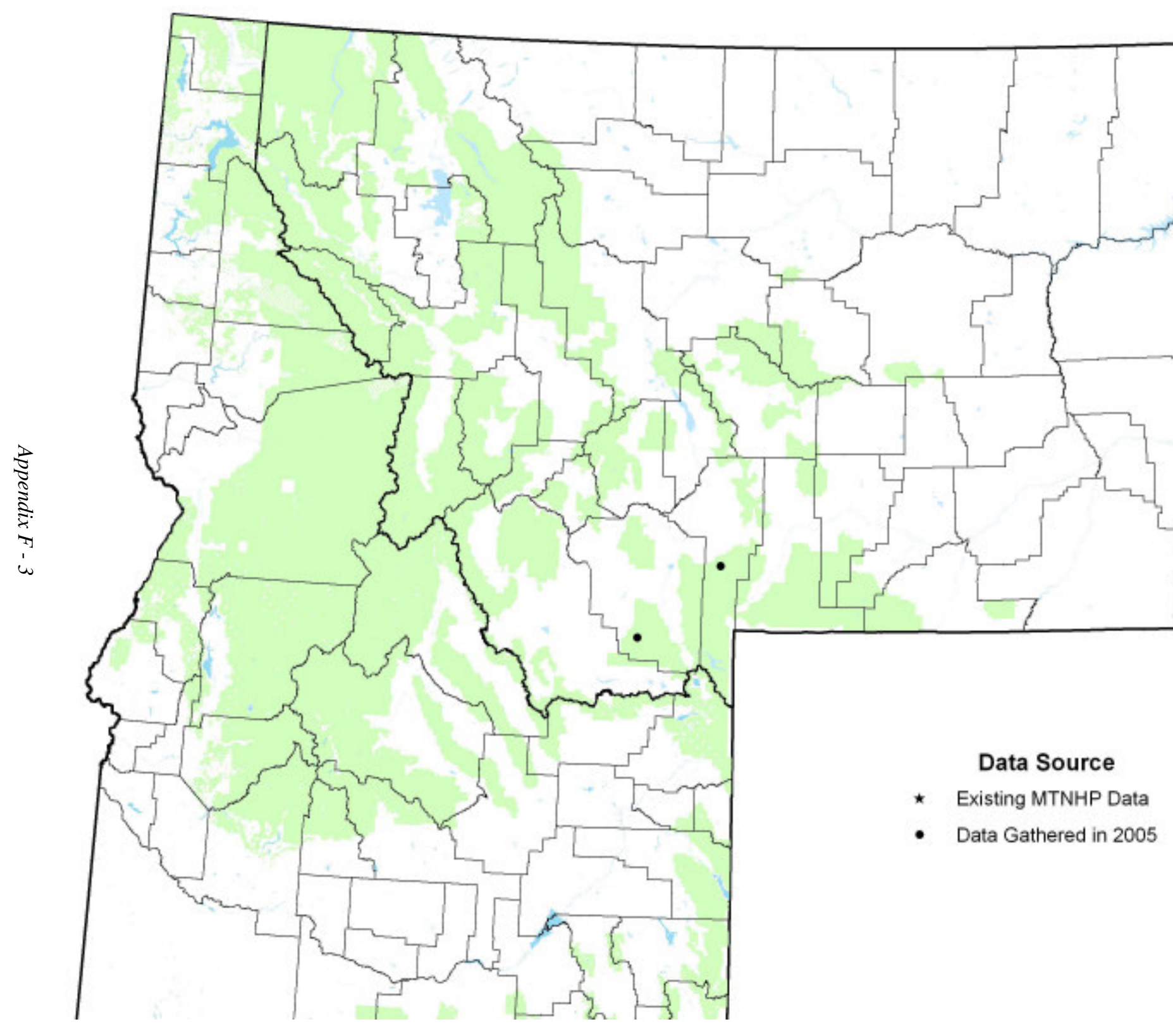


Toothless Column (Columella edentula)

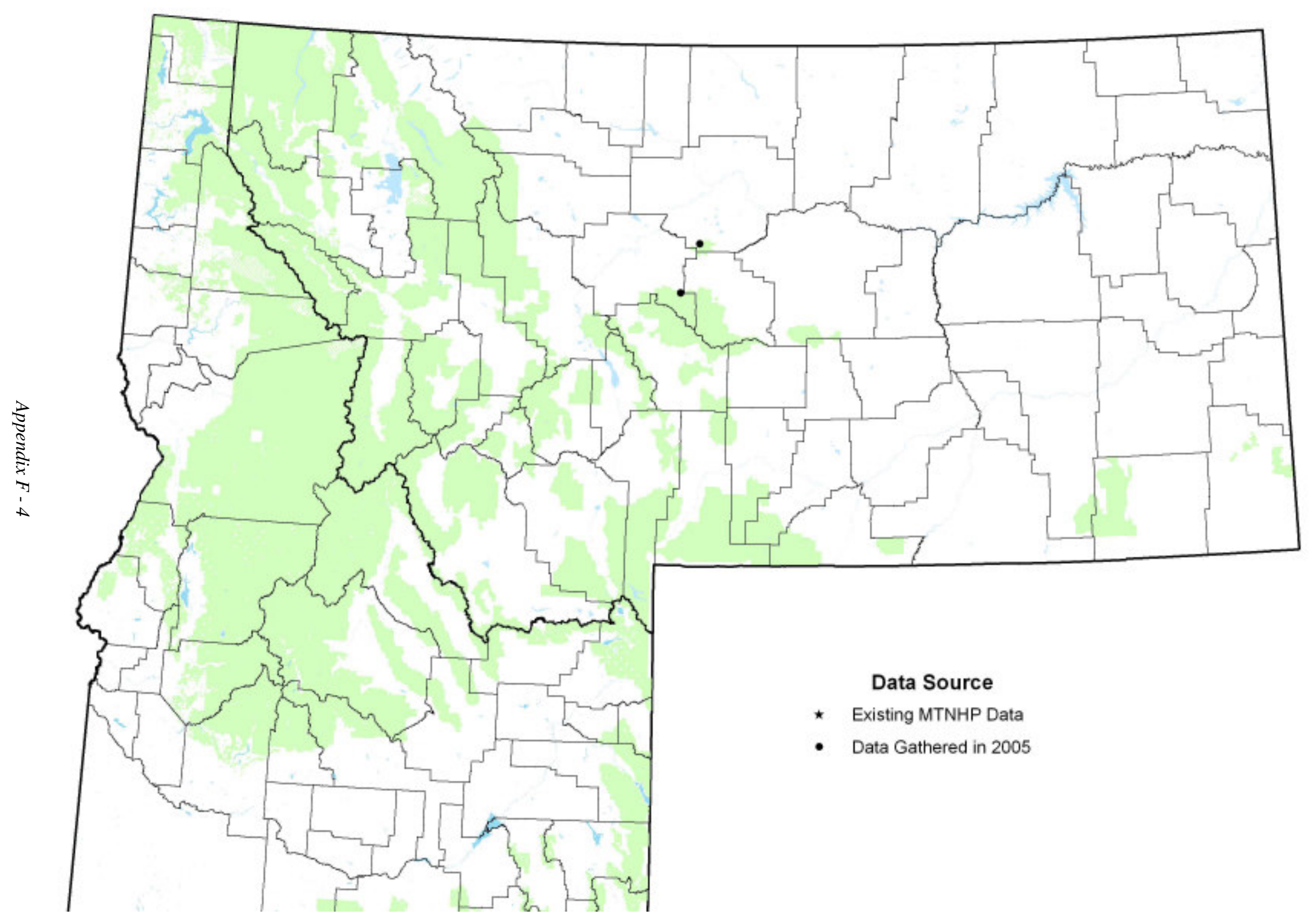




\section{Coeur d'Alene Oregonian (Cryptomastix mullani)}

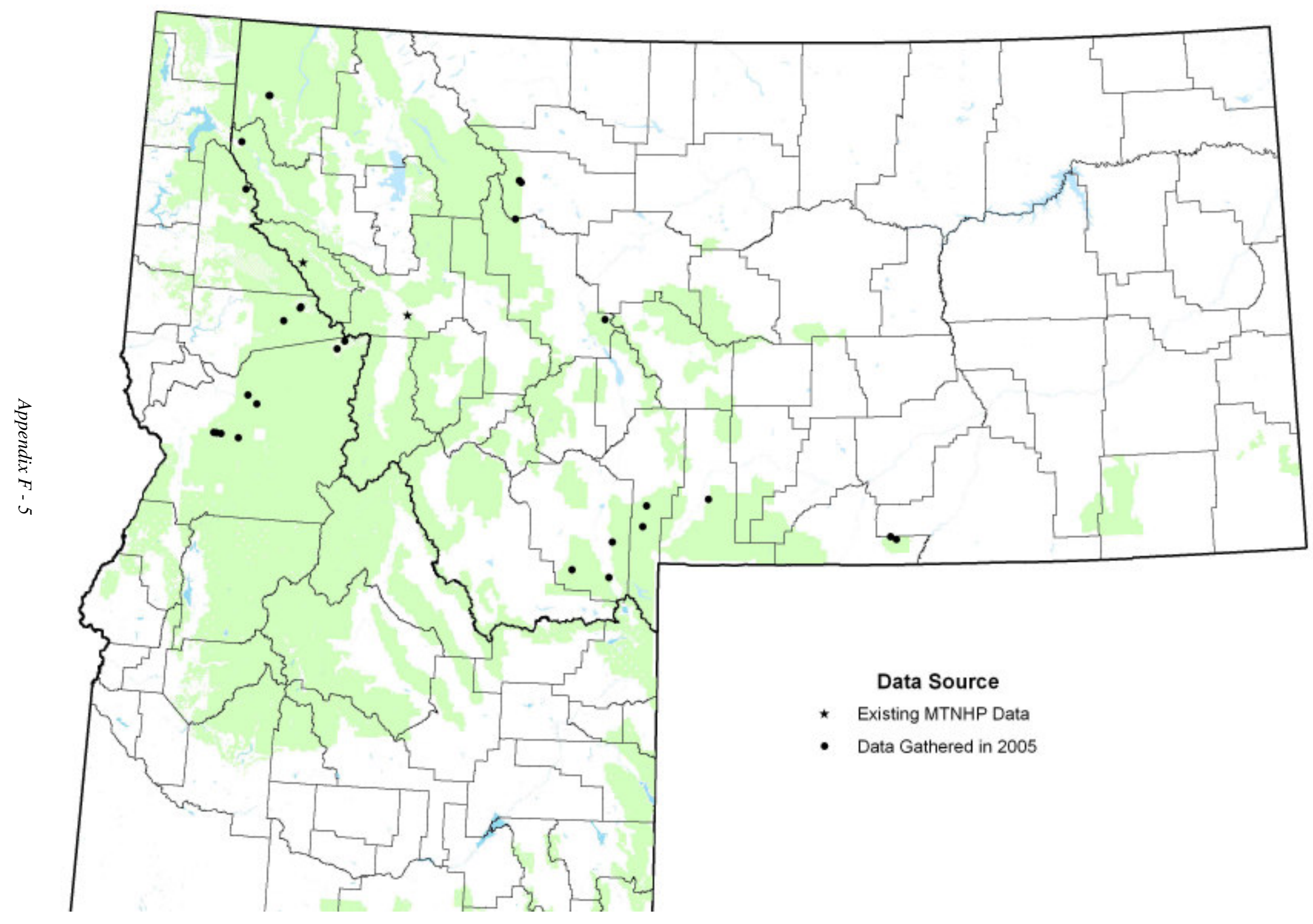




\section{Forest Disc (Discus whitneyi)}

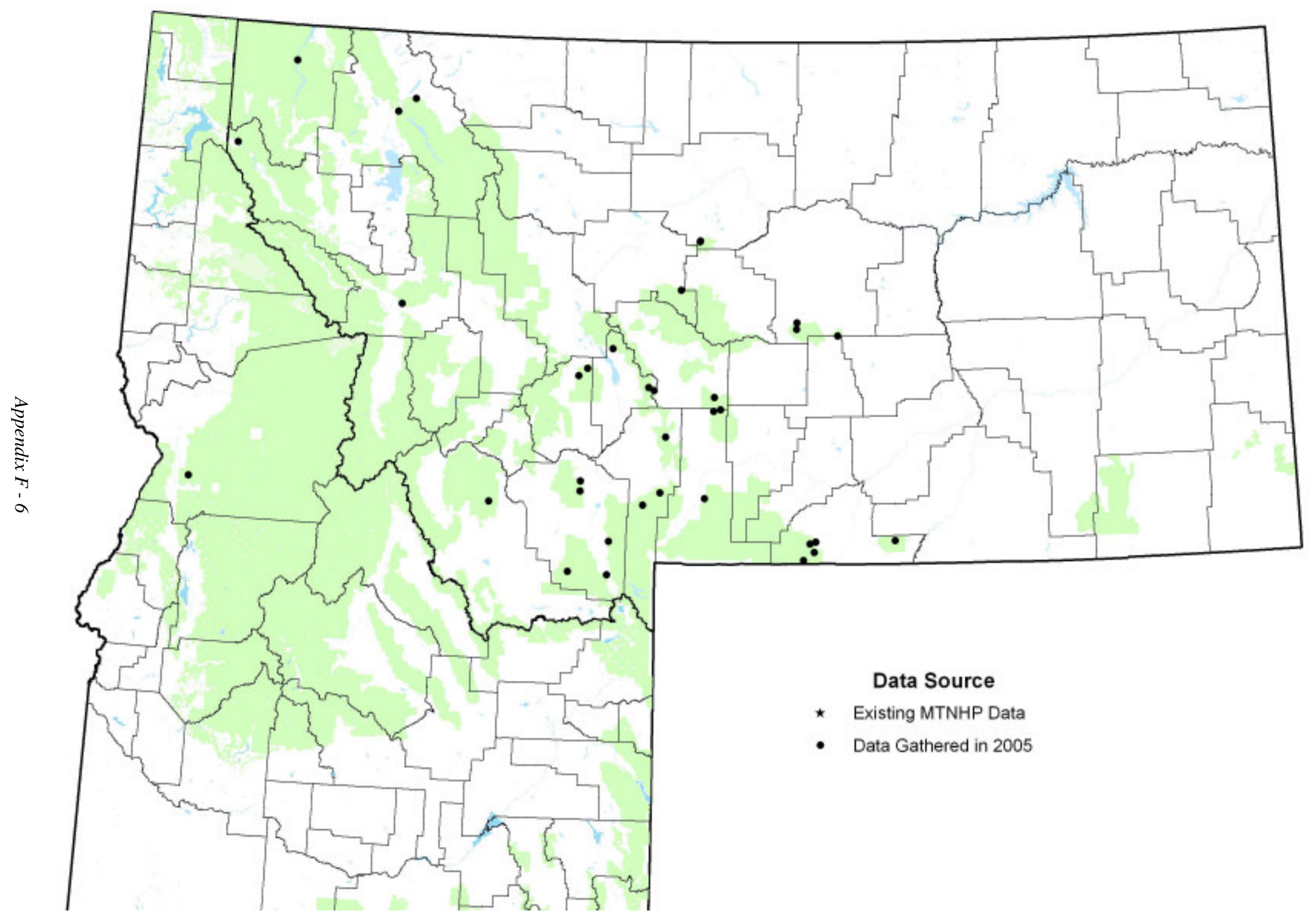




\section{Brown Hive (Euconulus fulvus)}

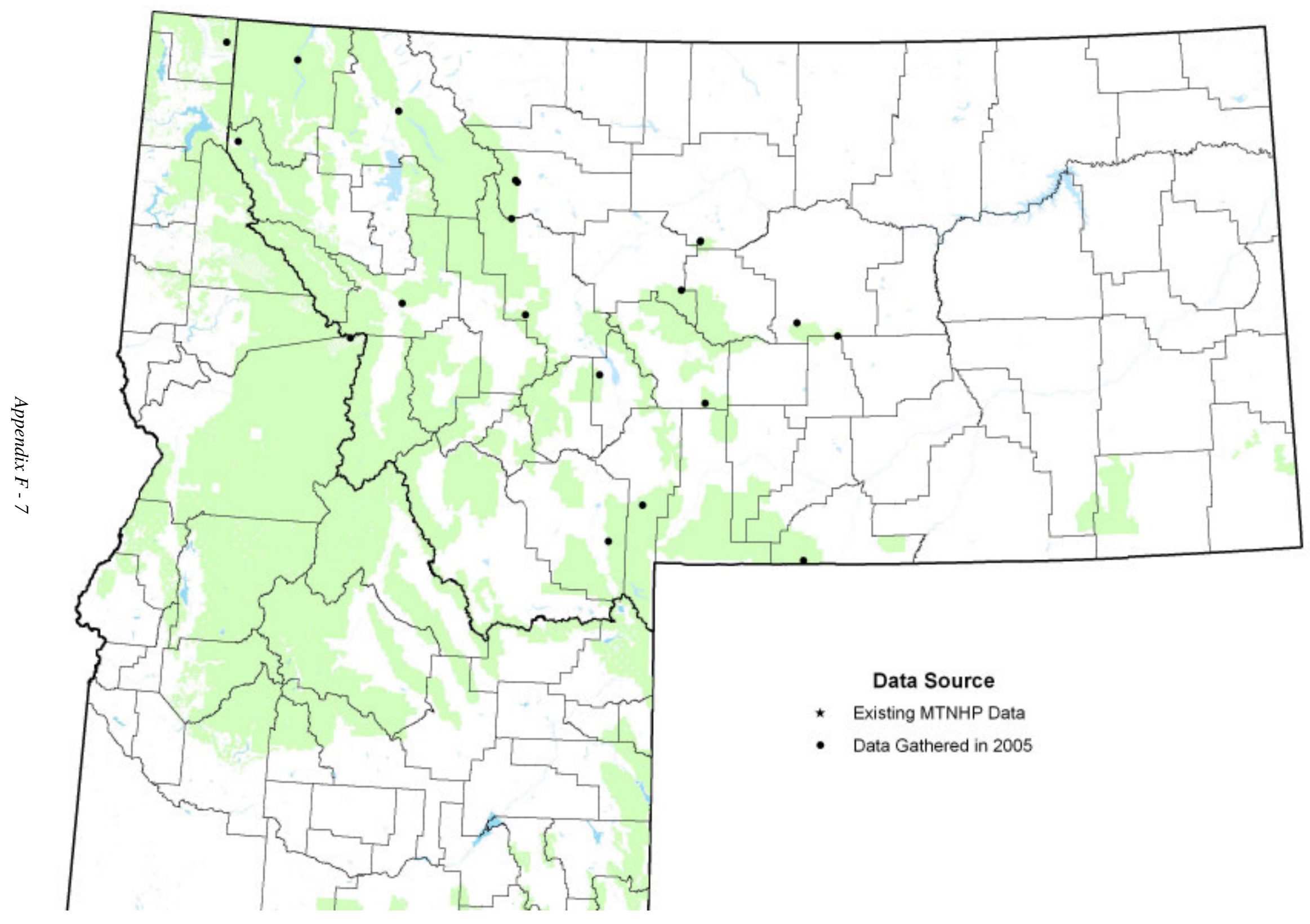


Minute Gem (Hawaiia minuscula)

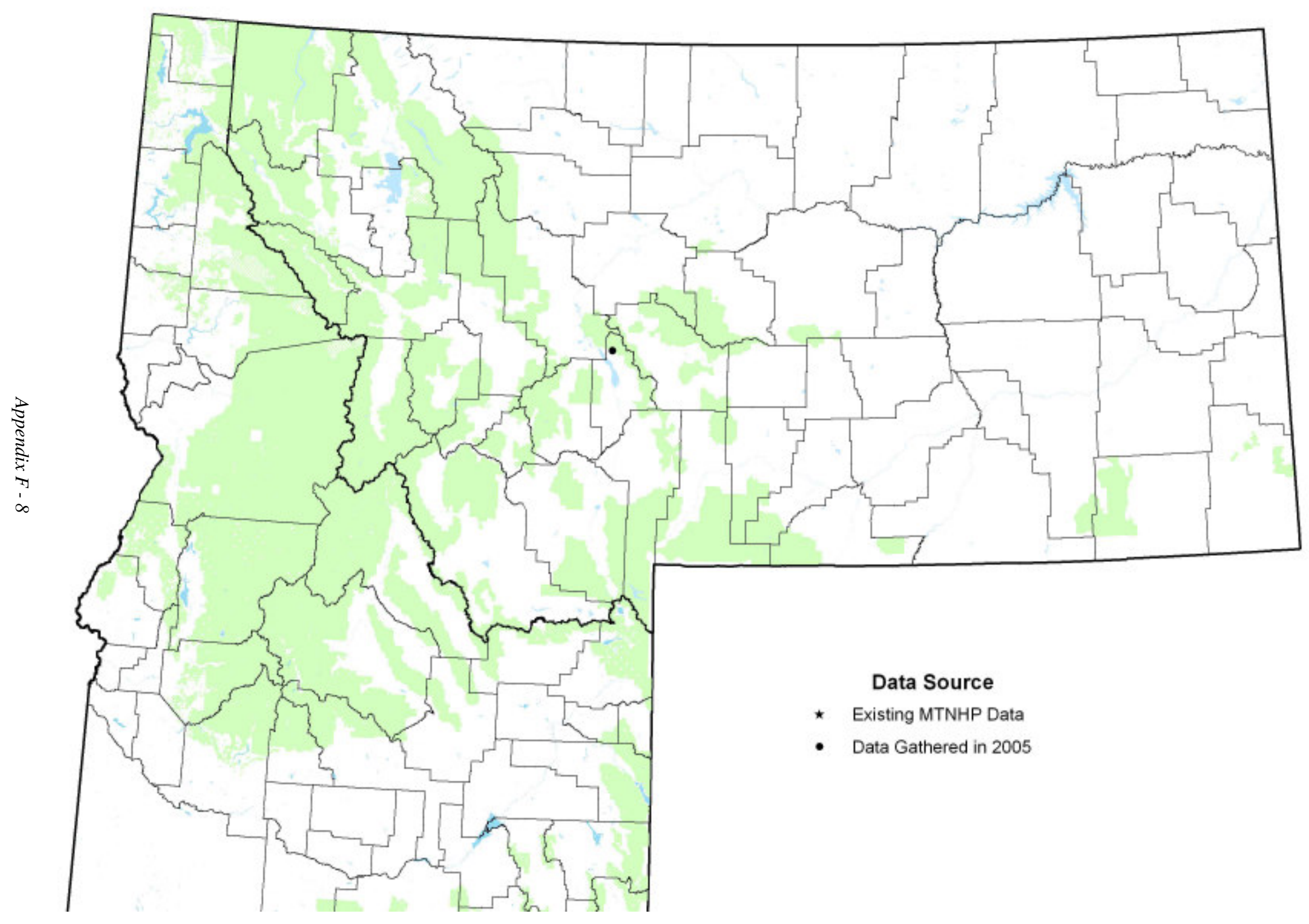




\section{Spruce Snail (Microphysula ingersolli)}

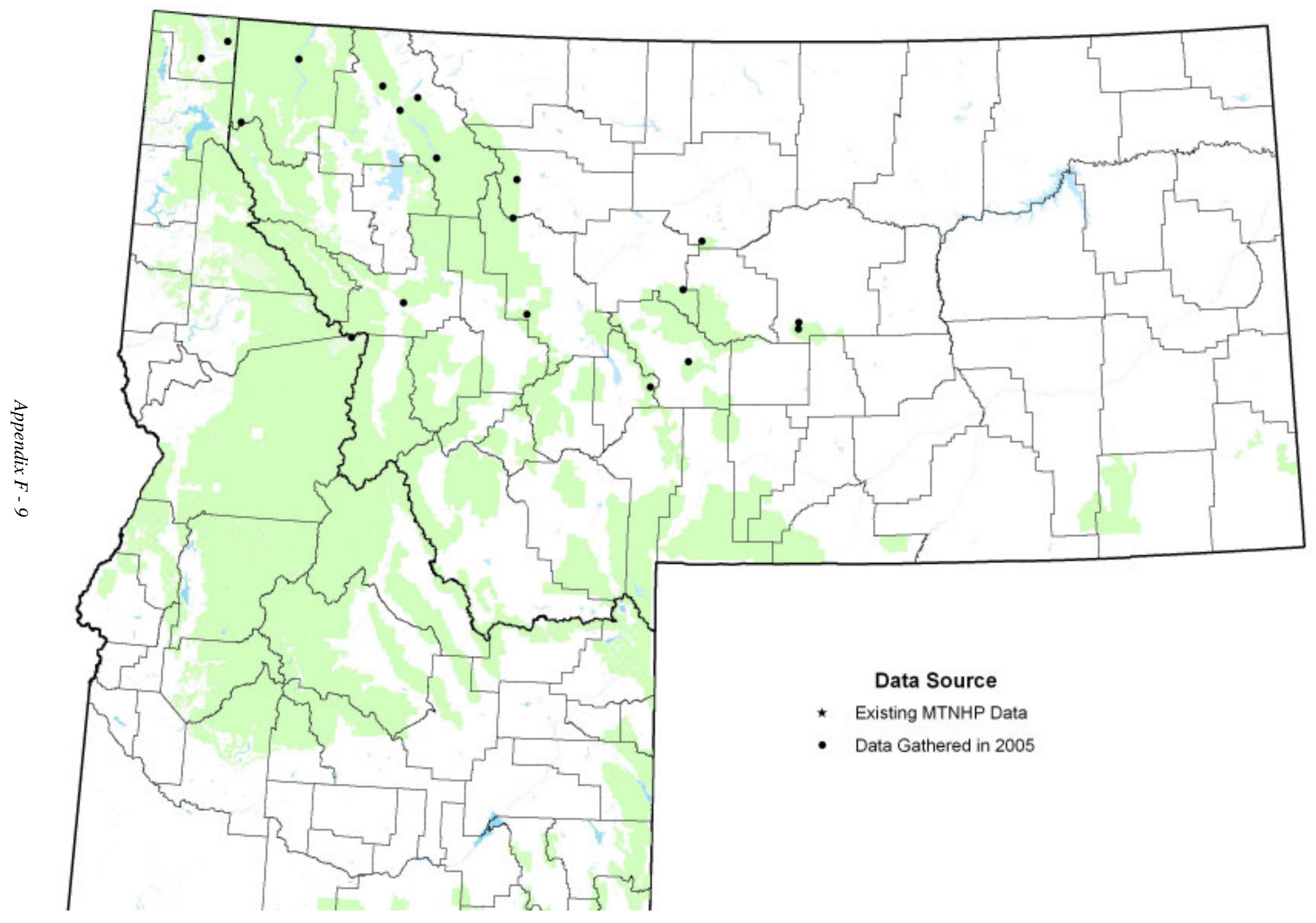




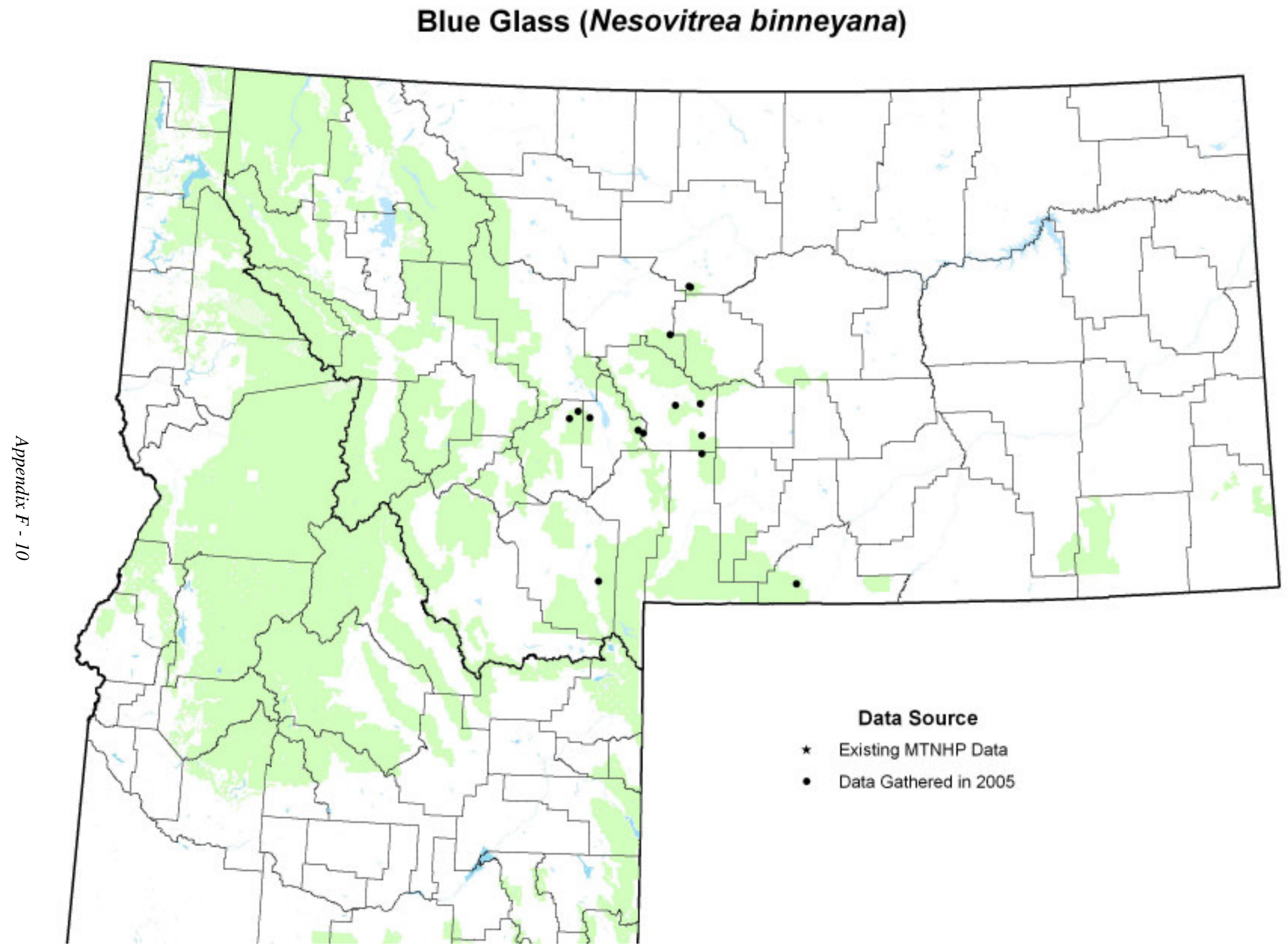


Rocky Mountainsnail (Oreohelix strigosa)

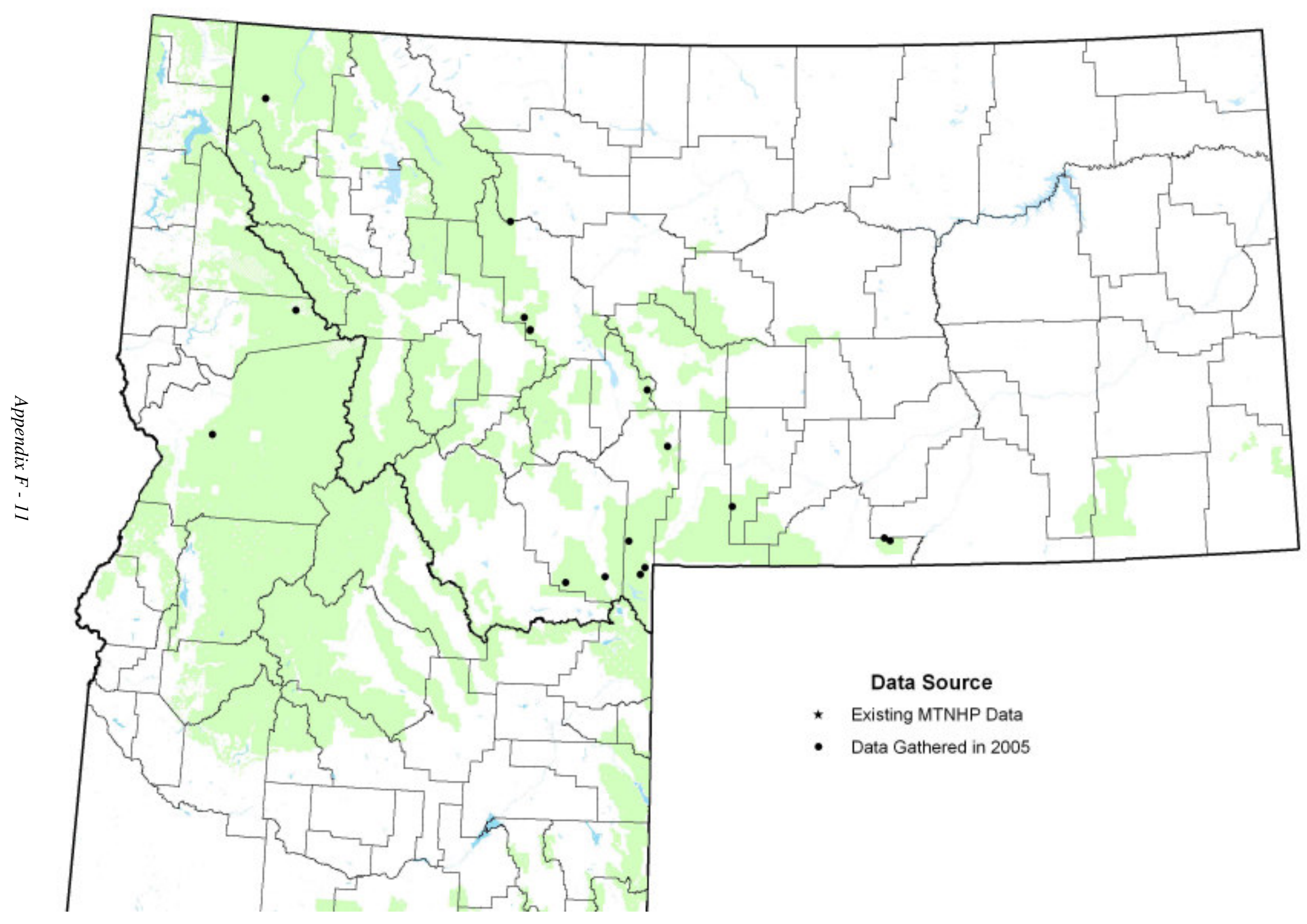


Subalpine Mountainsnail (Oreohelix subrudis)

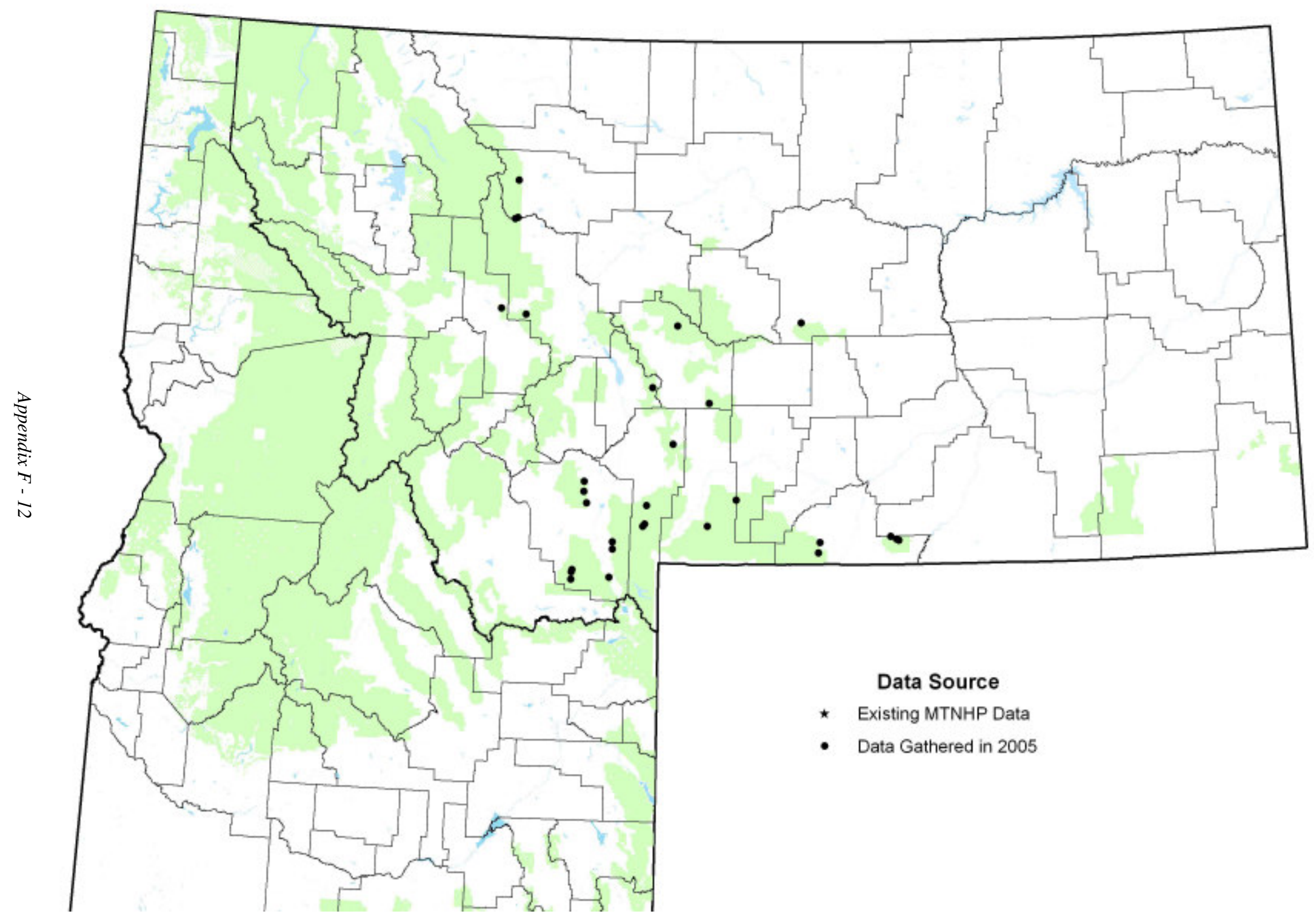




\section{Silky Vallonia (Vallonia cyclophorella)}

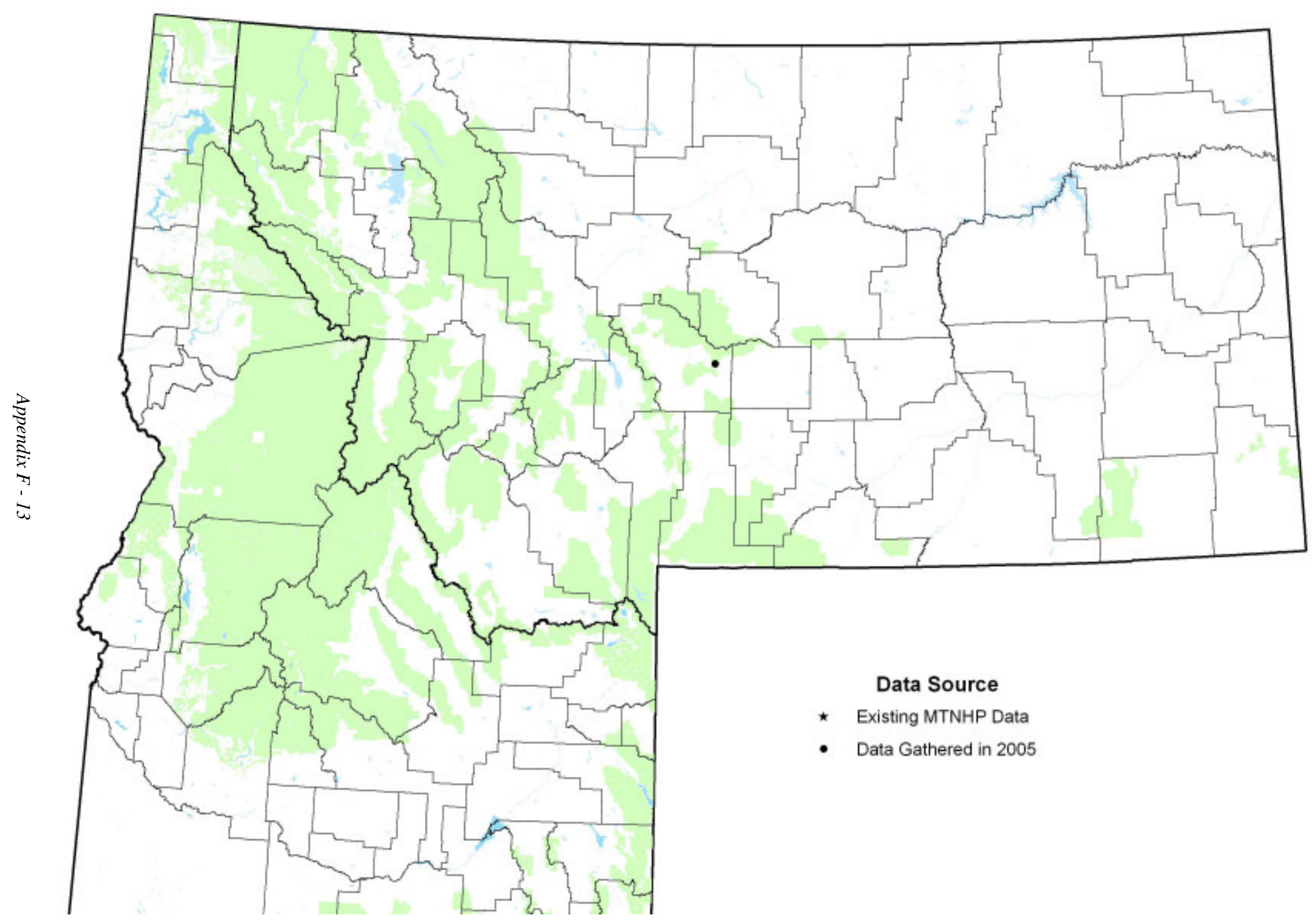


Multirib Vallonia (Vallonia gracilicosta)

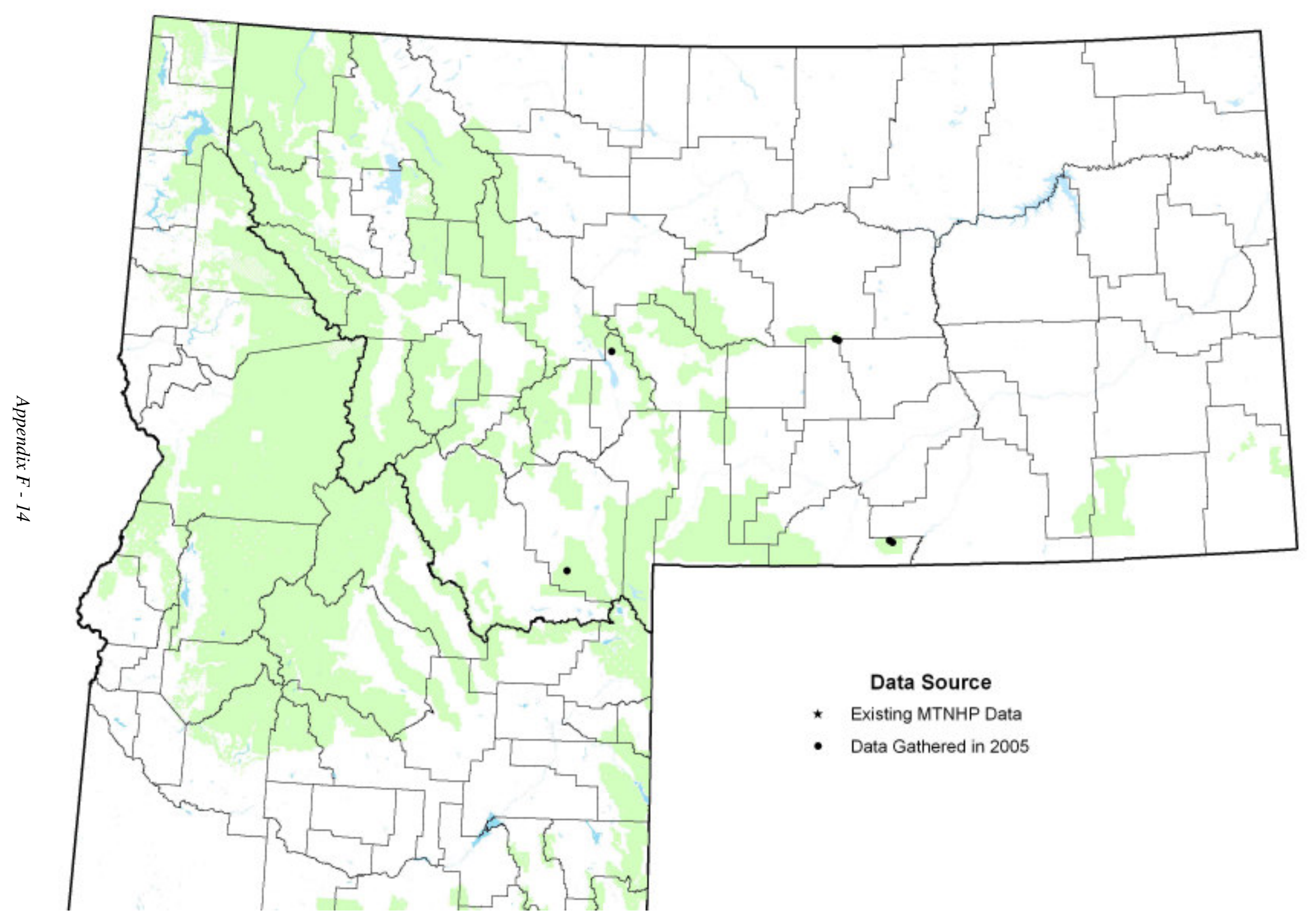




\section{Western Glass-snail (Vitrina pellucida)}

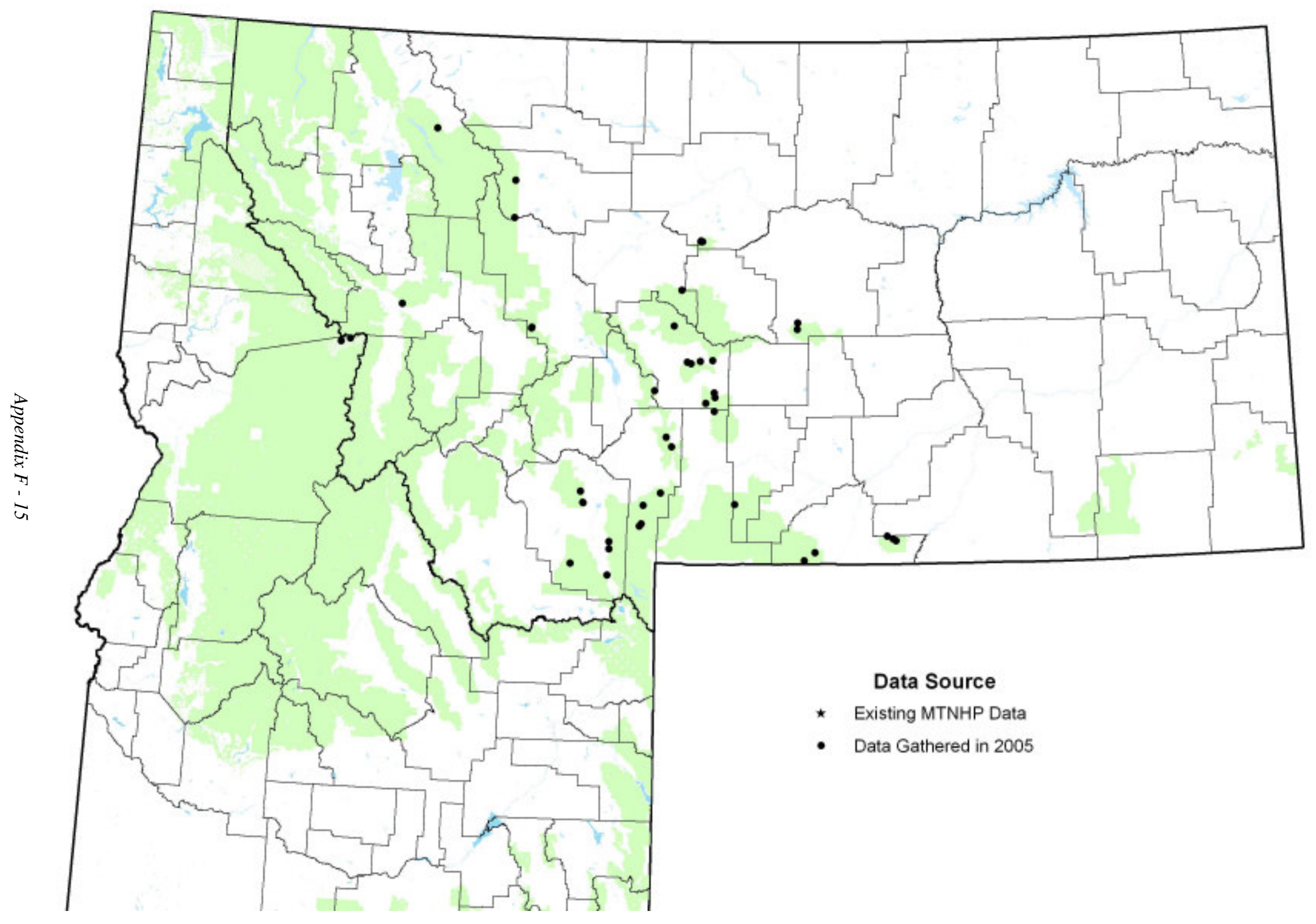




\section{Quick Gloss (Zonitoides arboreus)}

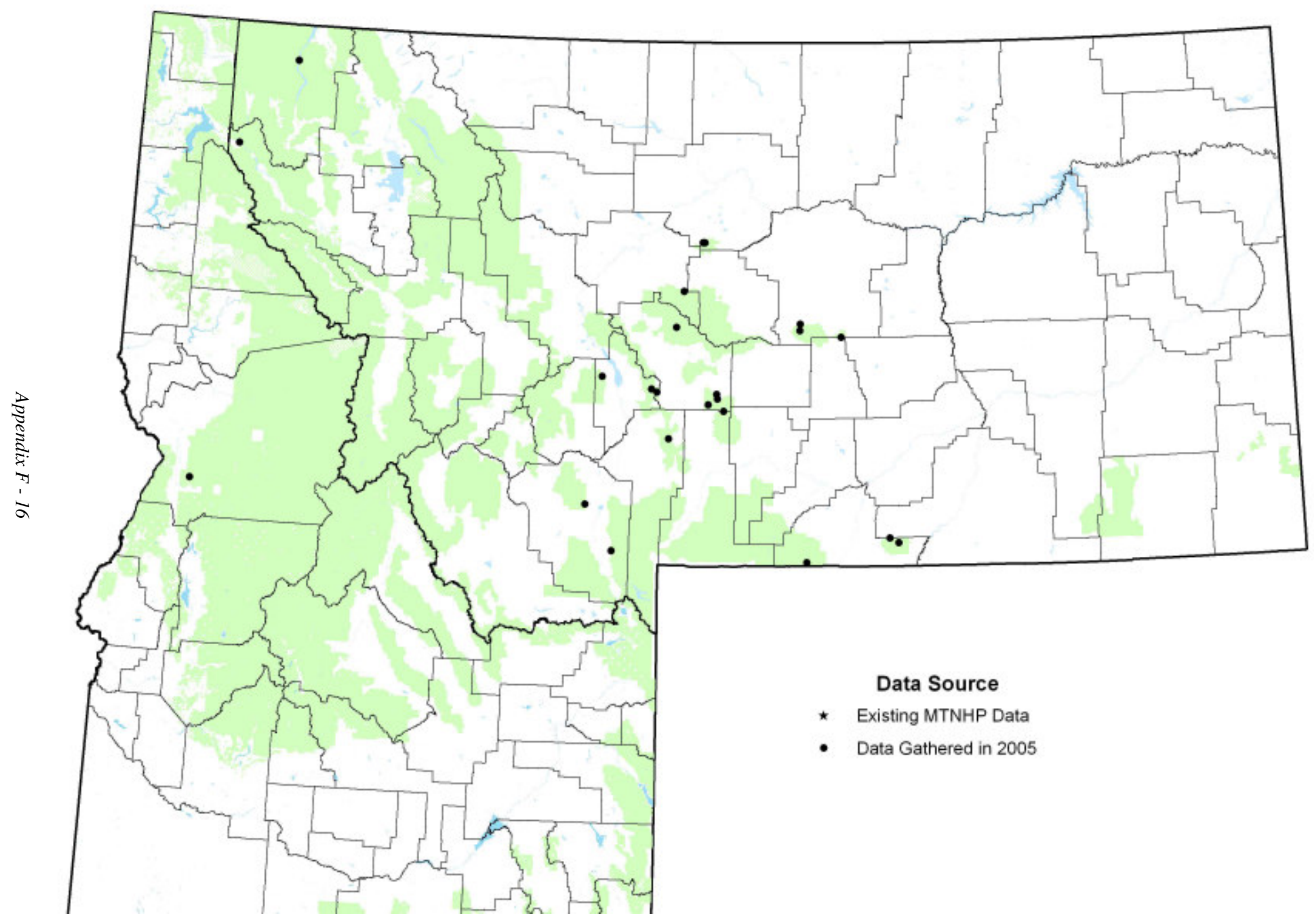




\section{Appendix G. Distribution Maps for Exotic Land Mollusks ON USFS REGION 1 LANDS}





\section{Black Arion (Arion ater)}

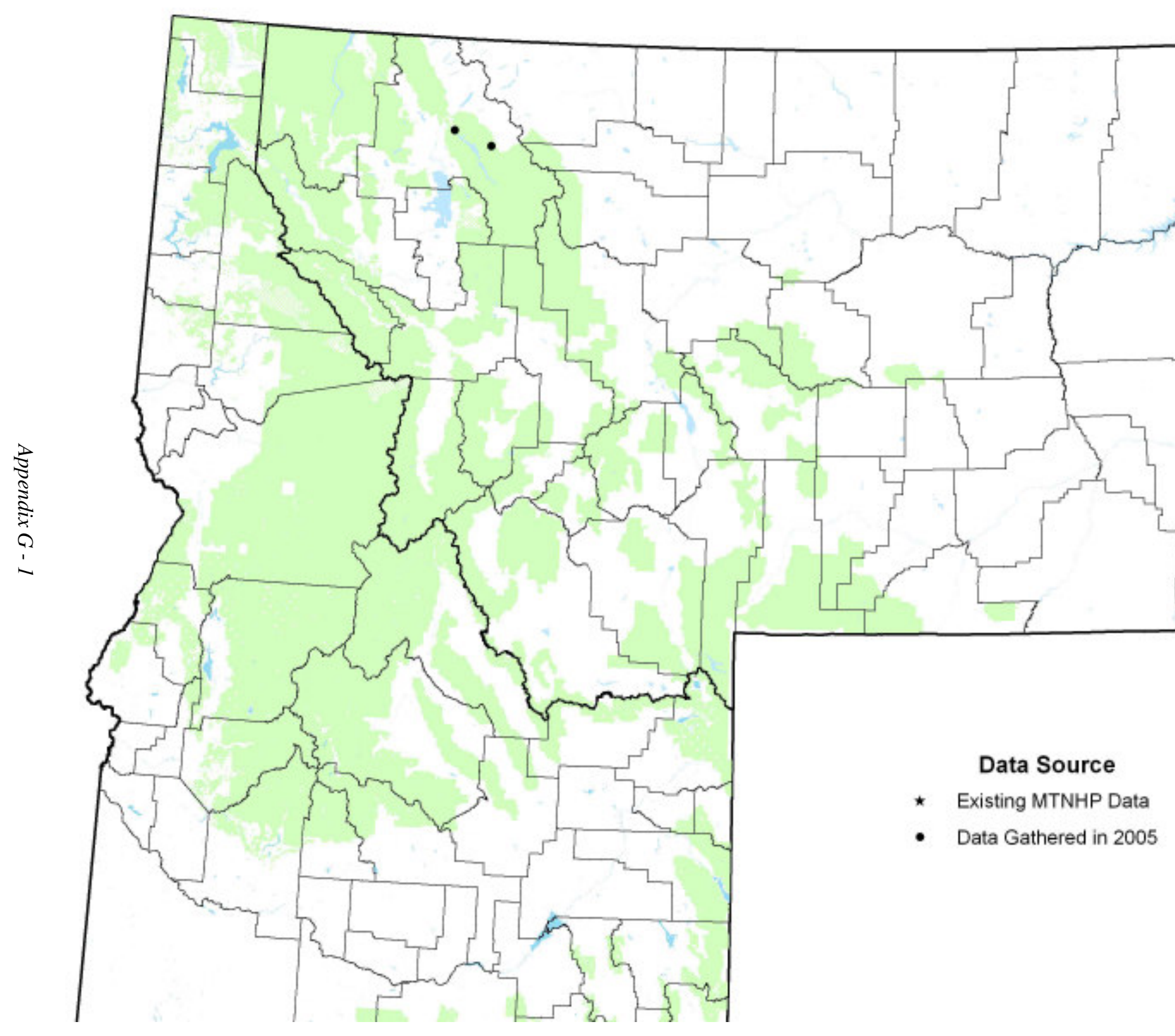




\section{Dusky Arion (Arion subfuscus)}

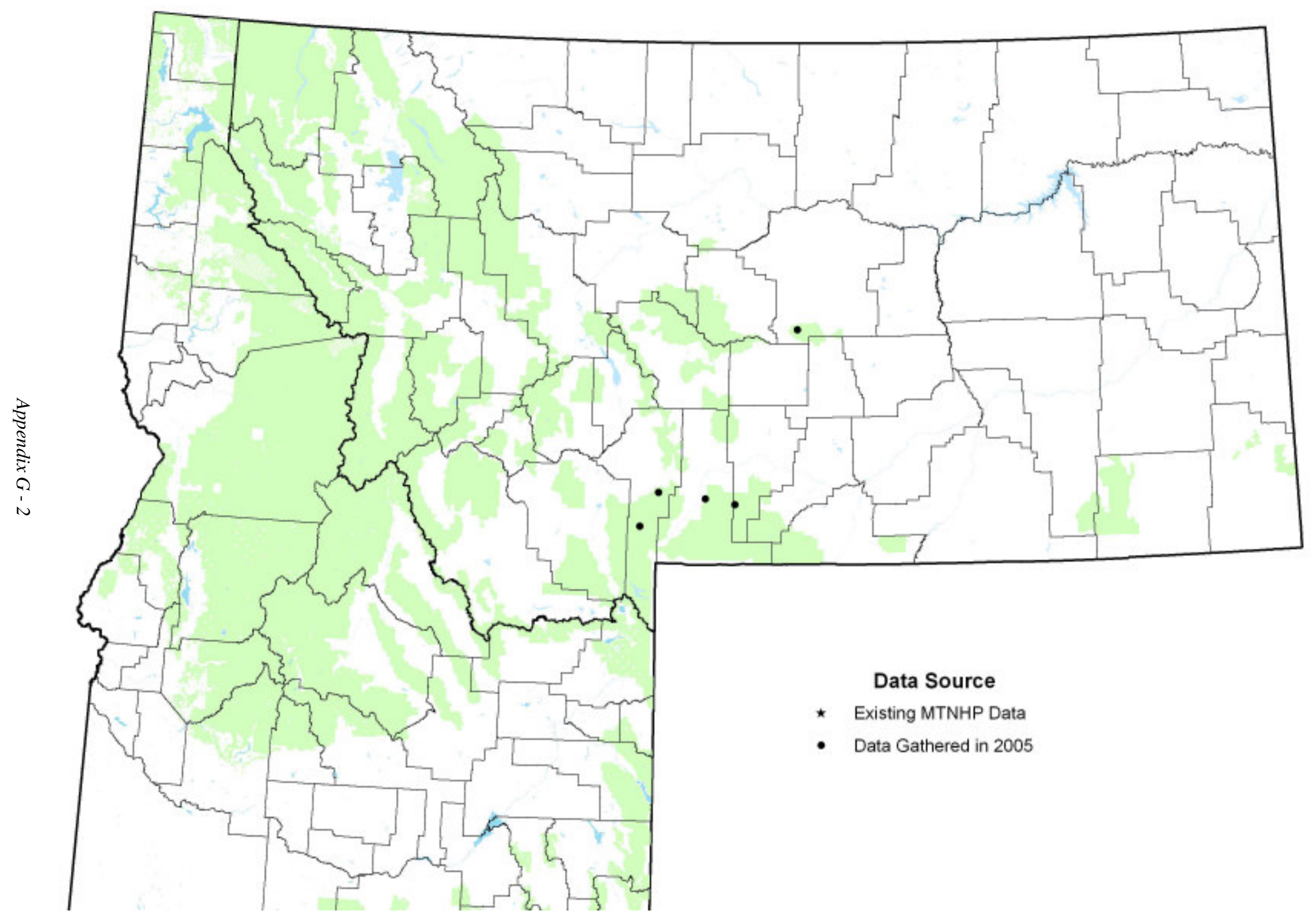


Meadow Slug (Deroceras laeve)

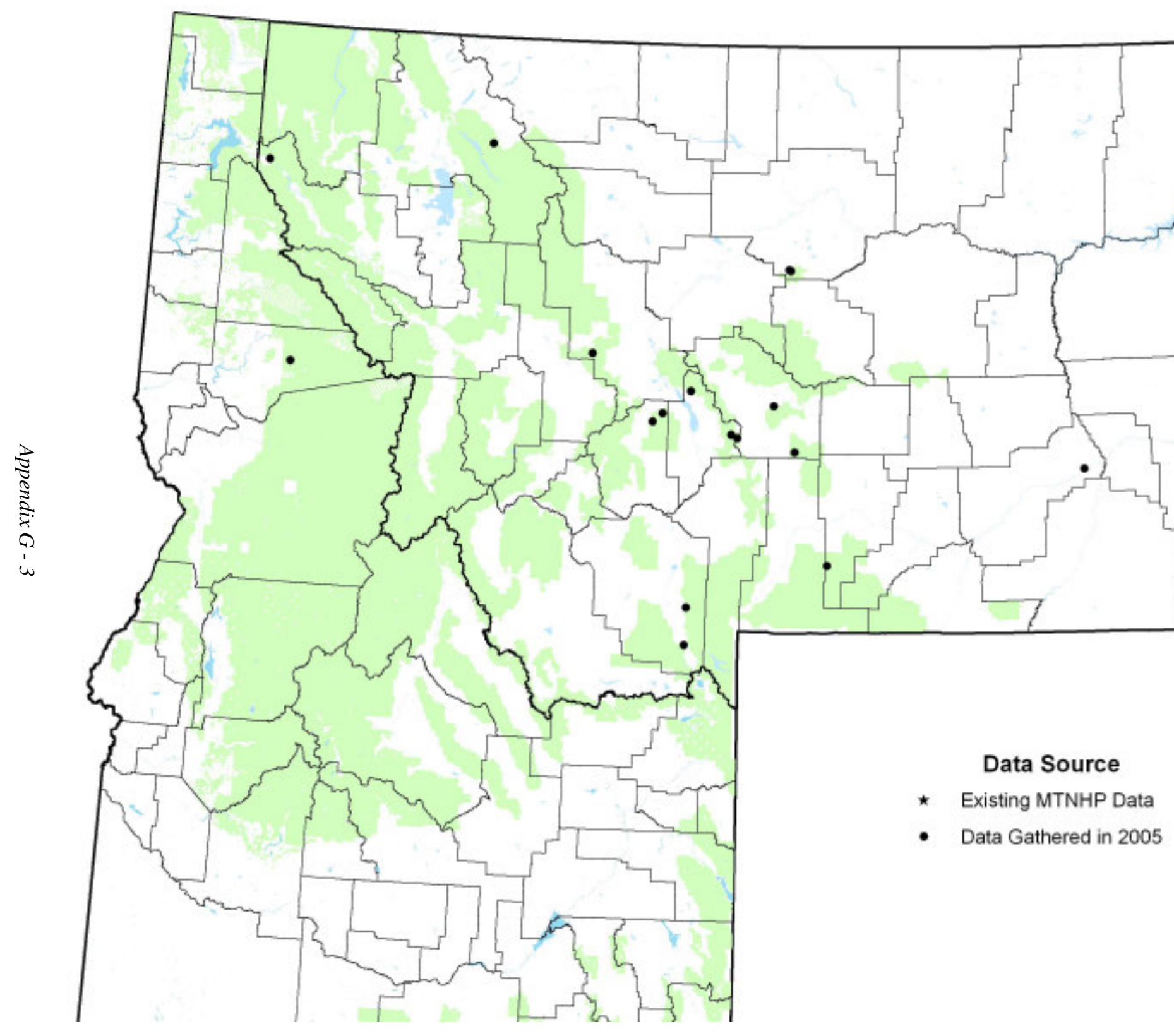




\section{Gray Fieldslug (Deroceras reticulatum)}

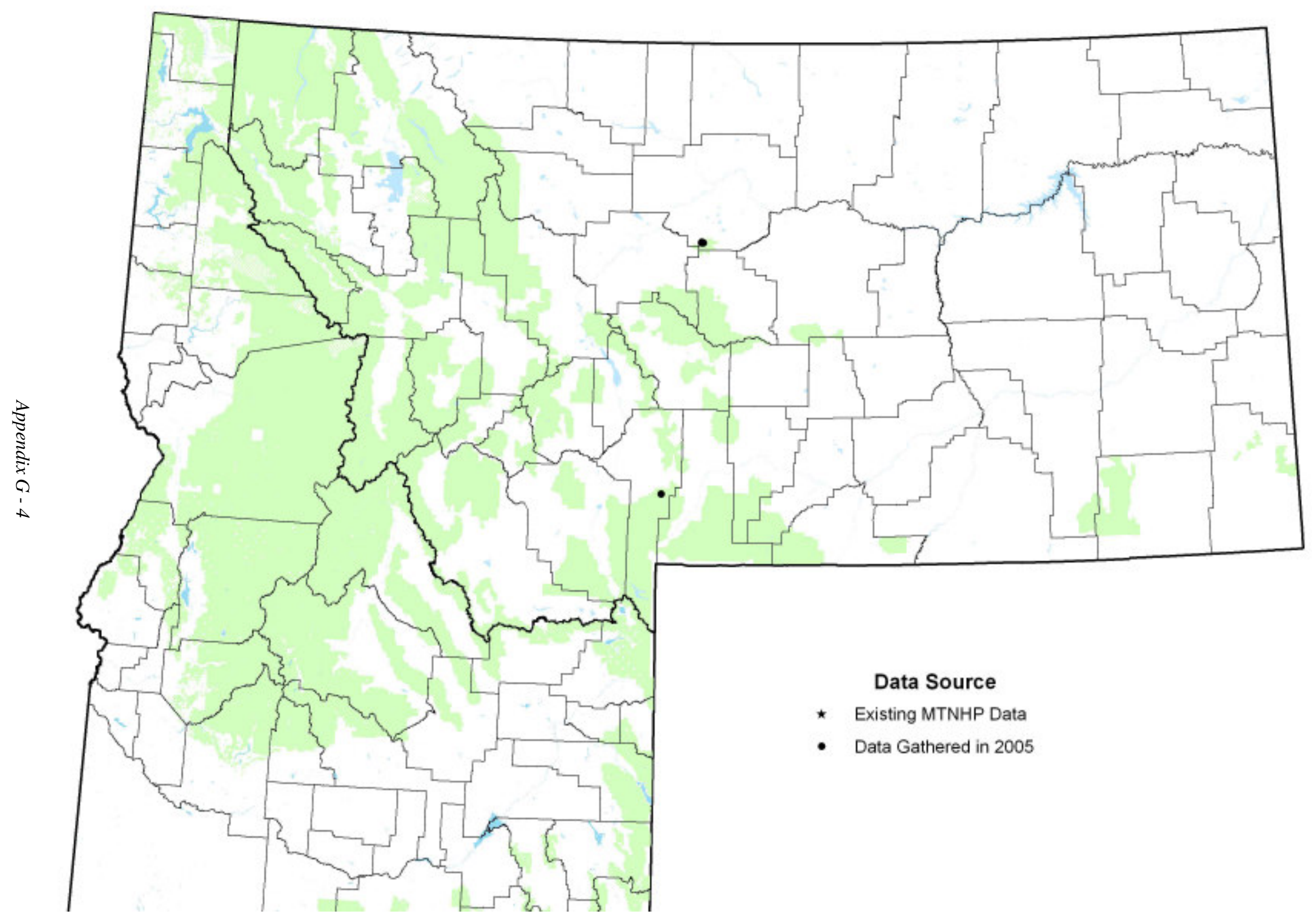


Giant Gardenslug (Limax maximus)

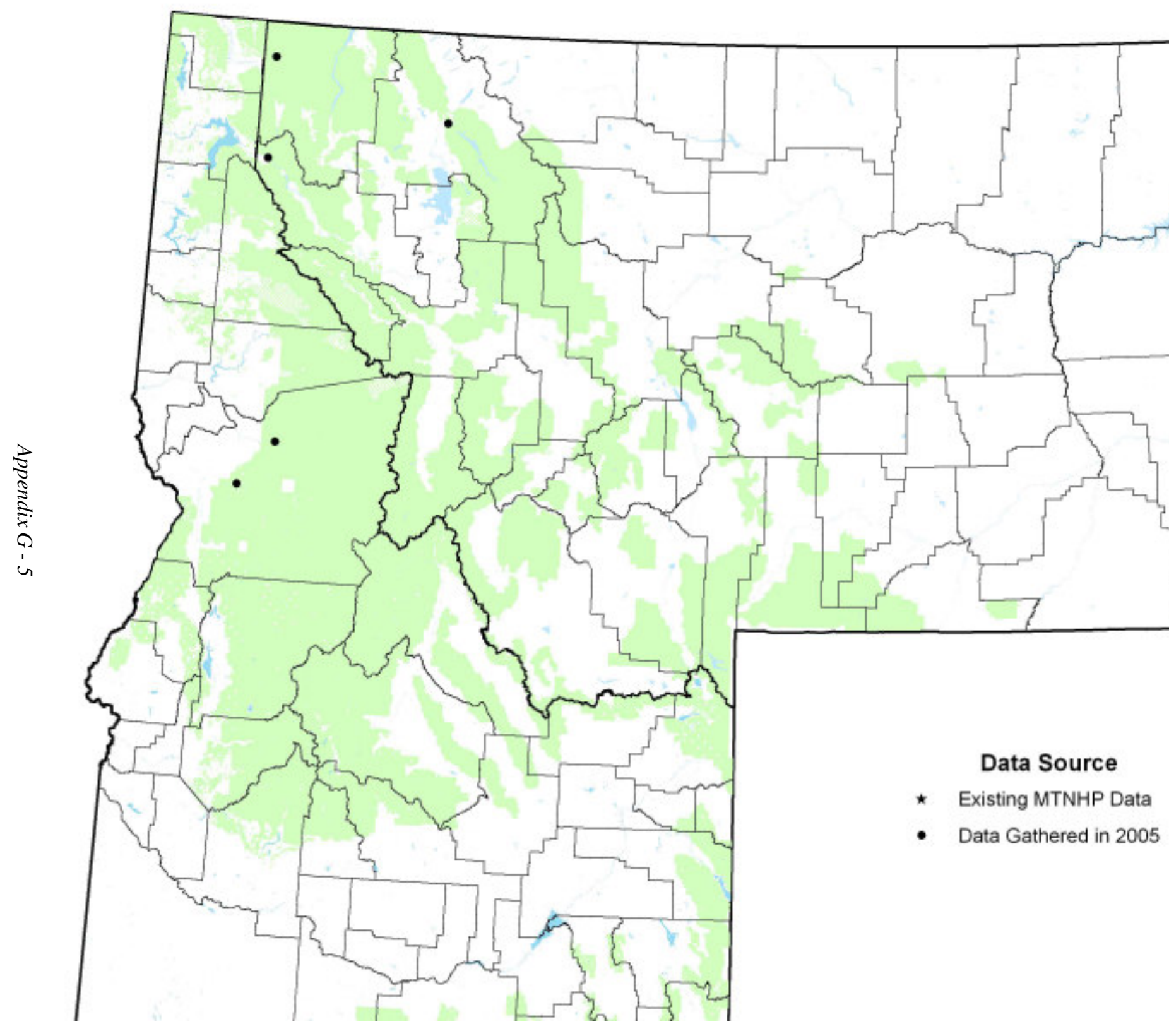

